\title{
Post Freudian Moses and Monotheism. The Eclipse of the Dawn of Conscience Egypt, the 1928 implant of Dogmatic Aberrations, Environmental Necrosis and Mutation of Tropical Diseases
}

\section{JH Wassili and Cyril Baradaeus*}

The Samaritan Biochemists, 279 Khaled ben Waleid, Seidi Gaber, Alexandria, Egypt

*Corresponding author: Cyril Baradaeus, The Samaritan Biochemists, 279 Khaled ben Waleid, Seidi Gaber, Alexandria, Egypt.
Received Date: September 14, 2020

Published Date: February 09, 2021

\begin{abstract}
According to Themistocles "I cannot fiddle, but I can make a small town into a great state".
Abbreviations: Syndrome of Abundant Superiority in Genetic Foolishness (SASGF); Hexose Polyester (HPE); Genetically modified organism (GMO); World Trade Center (WTC); dogmatic-mental cirrhosis (DMC); Supreme Council Armed Forces (SCAF); military-industrial complex (MIC); Post the assassination of the JF Kennedy, ML King, RF Kennedy (Post 1963-68) ; Cotton-Fields' Syndrome (CFS); Muslim Brotherhood (MB); USpolitical Bureau (US-PB); River Nile (RN); Depleted Uranium munitions (DUM); 2,4,6-Trinitrotoluene (TNT); Hexahydro,1,3,5-trinitro-1,3,5-triazine (RDX); US-Goebbels' media (US-GM); Imbecile-in-Chief (I-in-C); Posttraumatic Stress Disorder (PTSD).
\end{abstract}

\section{Dedication}

This manuscript is dedicated to (A) the 2013-Egyptian ladies who highlighted the risks of the dogmatic Führer Mursi, obliterated the Wahhabi nest of darkness which captivated the psyche of Egypt by the trio-Hempher, GM Bell and TE Lawrence and made it possible for General Sissi to liberalize Egypt, (B) secular and cultural aptitude and humanitarian quests of N. Sawiris and (C) the leadership and thoughts of Karima El Hefnawi, Myriam Milad and Dina Guirguis will always be remembered, as well.

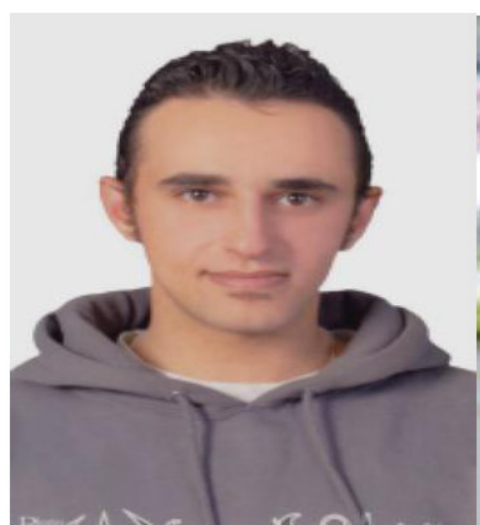

Khaled Mohamed Saeed

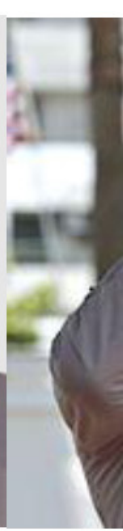

Annus Mirabilis: 2013

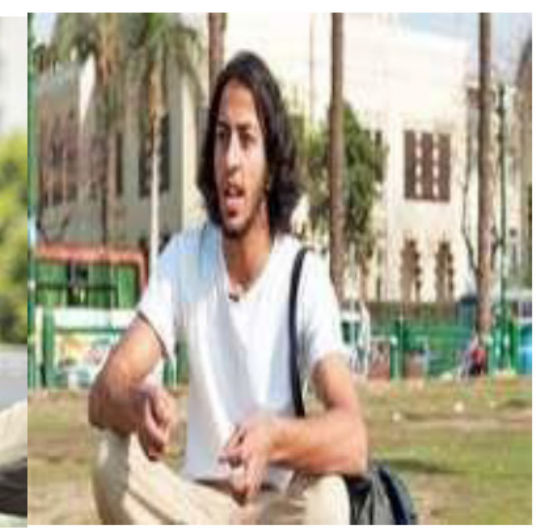

Menas Daniel 
Wait for me, and I'll come back, Wait it was a 1400 years estrangement.

Wait through autumn's yellow rains, And its tedium. Steel your heart and do not grieve, Wait through winter's haze, Wait through wind and raging storm, Wait through summer's blaze.

Wait when others wait no more, When my letters stop, Wait with hope that never wanes, Wait and don 't give up. Wait for me and I'll come back, Patience, dear one, learn.

Turn away from those who say, That I'll not return. Let my son and mother weep, Tears of sorrow,

let Friends insist that it is time, That you must forget. Do not listen to their kind, Words of sympathy.

Do not join them if they drink, To my memory. Wait for me.

Let those who don't - Once I'm back with you -

Let them say that it was luck, That had seen us through. You and I alone will know That I safely came, Spiting every kind of death, Through that lethal flame, Just because you learned to wait, Staunchly, stubbornly,

And like no one else on earth, Waited, love, for me.

\section{Konstantin Simonow}

The noble acts of Menas Daniel and Khaled Saeed are etched on the manuscripts of Egypt's 8000 years civilization. Both sacrificed their lives for the Annus Mirabilis: 2013. At this precarious point of rampant political instability, greed of the multinationals to monopolize the sources of energy and food resources, the cowboy chemistry of GMOs, HPE, etc., necessitated the dogmaticenslavement of the bedouins. Considering the long-range impacts of these designs of the political illiterates, the imminent deforestation of education and medical care of the dispossessed and environmental necrosis, it is deemed essential to circulate our highlights and psychoanalytical critique of available data (Data, Figures 1-12). In contrast, the Egyptian toil which coined the first
"Supernatural or Metaphysical Polytheistic/ Monotheism Entity" has captivated the faculties of the two colonizing empires in might and knowledge, the Roman and Hellenic civilizations respectively. Mainly because the other parallels, e.g., the Persian Zoroastrianism, Mesopotamian Gilgamesh and Indian Chinese Buddhism were void of the flavour of Israelite's resolve, all remained captive to their local environment. Absolutely we are not witch hunting a given text, but rather inquiring into the impact of the theological trends on the environment's ruin, mental incapacitation, hate crimes, etc. Albeit, we both are Copt Orthodox denoted "heretics beyond any possible salvation" by our mothers, we are looking forward to pirating the brains of readers of this scientific medium to a rational exchange of thoughts on issues below.

When boyhood's fire was in my blood,

I read of Ancient Egyptian freemen/women,

For Ha Ka Patah who bravely stood, Thirty million Menas and

Khaled; And then I prayed I yet might see Our Ra-mosa in command,

And Egypt, long 1400 years arabization, reclaims its Ka once again!

And from that time, through wildest woe, That hope has shown a far light,

Nor could love's brightest summer glow Outshine that solemn starlight; It seemed to watch above my head In forum, field and fame,

Its angel voice sang round my bed, A Nation once again. It whispered too, that freedom's ark, And service high and holy, Would be profaned by feeling dark And passions vain or lowly; For, Freedom comes from God's right hand, And needs a godly train;

And righteous men and women must make our land Egypt $A$ nation once again!

TO Davis, (1814-1845) with modification

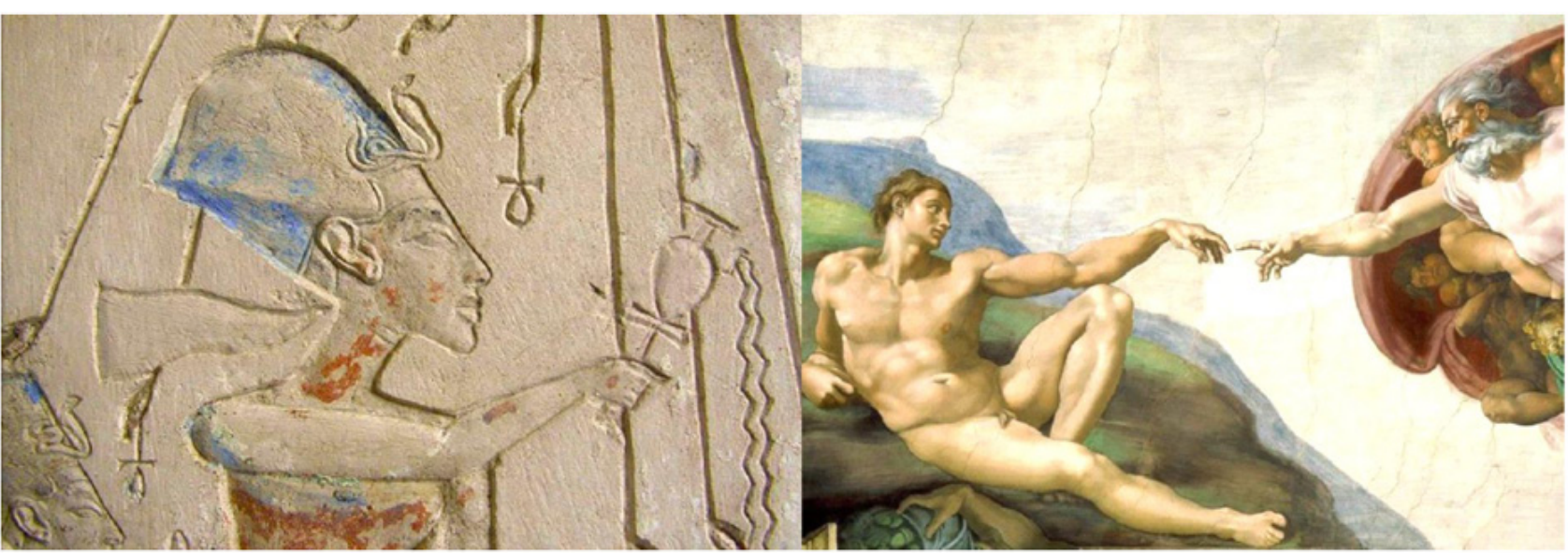

The Genesis and Evolution of the Omnipotent: The genius Ancient Egyptians, in particular the refined ethics of Pharaoh Akhenaten together with an elevated spirituality and puritanism, he pioneered the rhythm of monotheistic formulations. Thus, with great precisions, the canons of the Dawn of Conscience were

articulated. According to the dictates of the environment, prevailing intellect, culture and societal justice and sufficiency, evolution and de-evolution of Akhenatenistic thoughts became an inevitability. The yield was a wide spectral religious believes as we know it today. Thus, holding to the key of the After-Life while bathing in the Rays 
of Aten, Akhenaten's endeavor to communicate with the Creator was 3000 years prior to Michelangelo.

\section{Synopsis}

After many years in basic research, we came to realize the futility of the current feverish endeavors to secure research funds from various granting agencies for the purpose of identifying mechanisms of sedating pains. The rational alternative is to eradicate once and for all the causative factors of environmental intoxication-induced proliferating ailments. Very few are abusing nature and intoxicating environment with all possible refuse of by-products to attain the lavish ways of life of the fat cats of the military industrial complex, oil refineries, food industry, pharmaceuticals, beauty products, etc. Thus, releasing chemicals, detergents, food additives, pesticides, herbicides, HPE, micro-plastics, etc., became the life-threatening byproducts of the necessities of modern life. A preventive medication is economically more effective and time saving vis-à-vis the range of endless R\&D postulates of and grant applications for possible pain-relief pharmaceuticals, but not cures. Our habitant turned synthetic where natural lipids may be substituted with HPE, DNAengineering of available food commodities, humans may be cross genetically engineered with animals and insects to produce a better fighting machine, bacterial cells' DNA is considered a hard drive to store information, etc. Although, millions of dollars are yearly dedicated to AIDS, cancer research, etc., a complex of oil refineries, food industries, cosmetics, etc., are exponentially polluting the little of whatever left of living space. Concomitantly, the area of healthy living space is shrinking on the account of foolish synthesis of dogmatic wars by proxy, viz., Afghanistan, Kuwait, Iraq, Syria, Lebanon, Yemen, etc. This environmental ruin catalysed a mass flux of helpless refugees carrying an unknown range of mutated tropical and psychological aberrations to Europe and the USA. To make things worse, news media a trumpeted nauseate suggestions of the culturally barren I-in-C to: (i) consume hydroxychloroquine as a phenomenal and monumental remedy to a globally fatal viral infection (Covid-19) and/ or (ii) injection of the afflicted with antimicrobial detergents and as a deterrent; microwave the healthy.

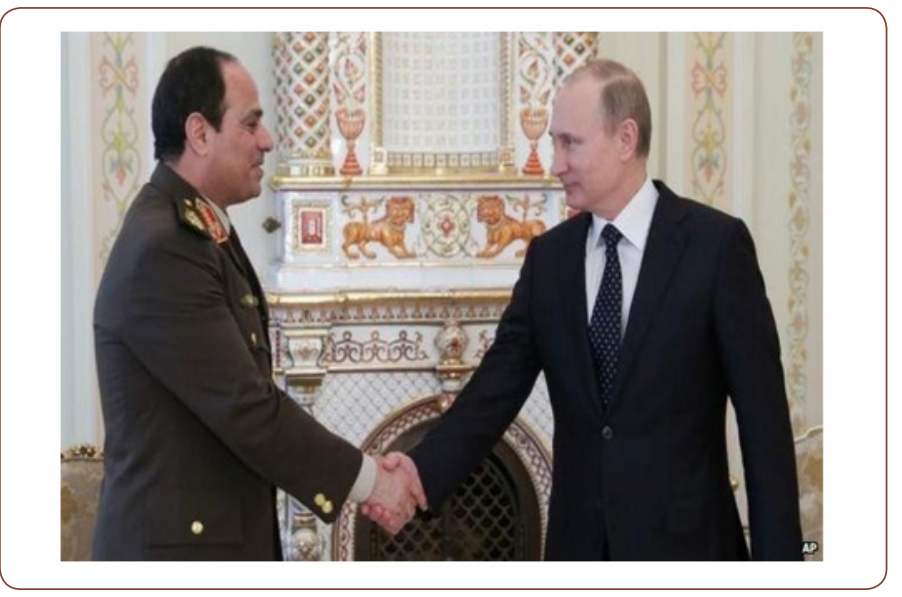

It is our contention; the massive 2013 Egyptian civil disobedience is fundamentally civil as the 1919 revolution. Visualize, the Russian president Vladimir Putin has cordially supported General Sissi as much in 1921; the Soviet leader Vladimir Lenin sent a letter to the
Egyptian counterpart Saad Zaghloul, reiterating his support for Egypt's 1919 revolution and offering support vis-à-vis the British colonizers. Reciprocally, in 1923, the Egyptian government issued a decree withdrawing its recognition of the Tsarist Russian consulate.

By all measures, both the 1919 and 2013 Egyptian revolutions are internationally recognized event. For example, Gandhi, the pillar of civil disobedience has favorably commented on the significance of 1919 Egyptian revolution as a "peaceful revolt: "Messages in the papers indicate that an upheaval or Home Rule is going on in Egypt. Large meetings are being held and resolutions passed by the Egyptians in order to gain political power by driving out Lord Cromer." Writing strongly on the subject, the London Times says that the movement should be suppressed. We do not believe it likely that it can be stopped. There are some brave persons among the Egyptians; and education is widespread. If the movement continues long enough, we believe that the British will grant self-government to the Egyptians [1].

\section{Summary and Thesis of Current Presentation}

Most likely, the recent event pertaining to the breakout of Covid-19 is indicative of the futility of the current scientific and medical endeavors to contain the long-range repercussions of environmental intoxication, viz., innocent versus intentionalmutations of pathogens and customizing intricate medical events to favor a given political course. These urgent quests are wasted according to the inevitabilities of the capitalists' greed and political narcissism of a political ignoramus, viz., the Coronavirus will be gone by April when the weather gets warmer. When the contention of an individual justifies the rape of all boundaries of Western ethics to attain personal ends, he would find it justifiable to impose his melancholies on peers. Most likely, the outbreak of covid-19 became a convenient distraction to his many catastrophic measures and utter failures. Irrational politicization of covid-19 in circulating news; specifically diluting the health threats of covid-19 to the elderly and its possible chronicity to the young became the corner stone of dissuading the populace of perceiving the utter failures of the I-in-C. For example, satire phraseologies at the UN in lieu of professional handling of: (i) the Persian and North Korean nuclear ambition, (ii) the wall of Mexico, if necessary at all, and (iii) failure to conclude a palatable agreement to the prime conflicting key elements of the Middle Eastern dilemma. The vomiting Ku-Klux Klan's chest-beating post harvesting the last breath of G Floyd and the abundantly disgraceful gesture of waving of the Bible were intentional manoeuvering of desperation. Ultimately to: (i) assume a 2nd term and (ii) evade grim corollaries of his never-ending 4 past years' rhetorical outburst. Prior to the reporting of The New England Medical Journal on the debacle of covid-19, we pioneered a publication detailing his miserable failure of combating covid-19 in this scientific media. In brief, for safe and positive conclusions to human's integrity and minimization of dogmatic-induced psychological and environmental aberrations; it is imperative to draft a mentally balanced individual as General Sissi to handle the UN intricate world's affairs. Below are few of his accomplishments in 4 years in a country, Egypt that is historically plagued with 
different colonialism each distilling its own spectrum of thoughts:

- Considering current uncertain mosaic of global politicking, Sissi is wisely managing the current Libyan- Turkish and Ethiopian threats to Egypt's integrity, safe borders and the life-giving RiverNile respectively. These two events were deliberately invoked on the assumption Sissi would react as Nasser's 1962-Yemen and 1967-Israel. Although both presidents are graduates of the same school, Sissi showed superior and distinct talents in dealing with catastrophic and life-threatening circumstance. It does not take two goat-heads to speculate with certainty on the prime force behind fueling these dogmatic hostilities, Erdogan. Nonetheless, Sissi has saved the hate-pregnant Middle East of costly and unnecessary wars à la JF Kennedy wise management of the Cuban affair,

- In 2013, General Sissi inherited a country plagued with actively fermenting political-dogmatic strife as of 1971. Obviously, General Sissi is a product of an emotionally and mentally stable environment, as prompted gestures inclusive of equality and liberty for all. In contrast, the icon General Washington who preached biased and selective tunes of liberty for early white settlers as it turned out, he and his wife, Martha, owned about 300 black slaves,

- $\quad$ Lincoln settled the US moral, constitutional and societal crises during a time and life-consuming 5 years civil war with total casualties of 750000, that is more than the US losses in WW-I and II together. However, sizable remnants of racial inequality could be identified all over the various states of the USA. General Sissi was able to manage the 2013-Kerdasah and Rabaa Al Adaweyah dogmatically flared war of attrition against the state of Egypt in a week with minimal casualties. In contrast to Sadat's Munchausenmental health problems who called for the liberation of Sinai at the cost of one million Egyptian fatalities and war with Ethiopia to secure Egypt's share of the River Nile's water, General Sissi opted for diplomatic avenues of negotiations and peaceful UN resolutions. Thus, his steely and well-balanced character salvaged the Middle East of compounding human miseries and financial losses expected of unnecessary wars,

- Competently, the British (Hempher the founder of Wahhabi sect, Gertrude Bell and TE Lawrence) had established a well rooted dogmatic drive in Egypt to expedite it when necessary. In response to $\boldsymbol{M B}$ crimes of massive slaughter of civilians and rampant destruction of public properties, appropriately army units were mobilized to quench the volatile dogmatic flares of HajObama's thugs of Kerdasah and Raba'a al Adawiya 2013. It took few days with minimal civilian fatalities for the army to restore and secure civility to Cairo streets. By comparison, visualize the devastating losses in lives and properties during 1993-WACO and 1978-Jonestown. Of the nearly 1,000 church members who began the day in Jonestown's cult commune, only 33 survived. One-third of the victims were children. Many were killed by Jones' aides, who squirted cyanide down their throats. Indeed, it is pathetic to perceive lamentations of Haj-Obama's militants at Kerdasah and Raba'a al Adawiya 2013 over the demise of Mursi's presidency. At large, the borders of the nomadic Sheikdoms were knitted in sandy terrains. by the Jewish young lady Gertrude Bell as early as the 18th century. In brief, Sissi saved Egypt of further deterioration to Syria's model of Assad,

- $\quad$ According to a well investigative reporting entitled "When Europe Loved Islam by: M Hannun and S Spaan"; with Asiatic Mughal-style, the Wilmersdorf mosque, Brienner Street, Berlin was built 1923-25. At that distant time, the Germans displayed openness and flirted with Islam. The early 20th century saw similar emergence of the first Muslim communities in Western Europe. For various reasons, many nationals in Britain and the Netherlands converted to Islam.

Hamid, formerly Hugo Marcus, a gay Jewish philosopher, adopted Islam and engaged with the philosophers, viz., Goethe, Nietzsche, Spinoza, and Kant, to pursue his contention: Islam was a necessary component in crafting the "New Man." The Ahmadiyya mission built the Shah Jahan Mosque in Woking, England, 1889. P Henricus van der Hoog, a Dutch dermatologist adopted Islam during the period and religiously carried pilgrimage to Mecca, as well. Many others followed same route, e.g., Harry St. John Philby, a British intelligence officer who fathered the double agent Kim Philby, converted in Saudi Arabia, 1930 and became Abdullah, the Jewish writer Leopold Weiss, became Muhammad Asad. The son, Talal Asad, is one of the most influential anthropologists, etc.

Although motivations were cynical, WWI was the prime causative factor for the Western European governments to demonstrate tolerance, domesticate Muslims and have leading personalities adopting Islam as an expression of leniency. During World War I, France and Britain relied on their Muslim colonial subjects to serve on battlefields. This urgency called for Imams attached to Muslim brigades and availing halal necessities. Interestingly on the German side, a mosque was built in a prisoner of war camp in Wünsdorf to accommodate the captured Muslim soldiers. Ultimately, a mutual nomadic-Western discontent was initialized to brew until climaxed with the massive hate crimes and the swarming of refugees to Europe.

In the postwar period, the famous Shakib Arslan, pan-Islamists, was based in Geneva. His grandson is the contemporary Lebanese politician Walid Jumblatt who advocated the pan-Islamic message of resistance.

Regardless of their typical commitment to secularism, the French managed a variety of loopholes to finance the construction of the Grande Mosquée de Paris. Parisian municipality official P Fleurot proudly pointed "the mosque was an expression of France's gratitude, a commemorative memorial for the Muslim soldiers who fell in WWI on the country's behalf." In route to World War II, and during the war itself, Britain helped finance two mosques in London, while the Nazis who portrayed themselves as the protectors of Islam were leading the Kosovan, the Muslims of Eastern Europe, the Balkans, Crimea and the Caucasus' herd in the Soviet slaughterfields,

- On 18 September 1961, Dag Hammarskjöld, without 
prior approval from the USA and UK, was enrooted to negotiate a cease-fire between United Nations Operation in the Congo forces and Katangese troops under the rebel M Tshombe. Hammarskjöld and 16 passengers were perished when the carrier DC-6 crashed near Ndola. Typically, a CIA report claimed the KGB was responsible. However, a recent 1998, documents surfaced suggesting CIA, MI6, and Belgian mining interest were involved to "remove" Hammarskjöld. Specifically, the CIA director at the time, A Dulles noticeably marked "Dag is becoming troublesome ... and should be removed." Hammarskjöld's mission to bring peace to the mineralrich Katangese secession from the newly formed Republic of the Congo was contrary to the interests of those organizations,

- Secretary-General of the UN noted that his predecessor B Ghali, consistently gave voice to the poorest and least powerful members of the human family. Ghali steered the UN through a series of world conferences on the environment, population, human and women rights, and social development. Ghali had an ethically elevated conceptualization as boldly noted his Messianic vision: "For us, genocide was the gas chamber, what happened in Germany. We were not able to realize that with the machete you can create a genocide. Later we understand this." For his bias to elevated ethics, and contrary to both the USA and UK, he fiercely opposed the engaging power to quench civil war in Somalia and the disintegration of Yugoslavia: (I) his life was intentionally placed in peril while visiting Somalia and (II) the US aborted his tenure to the UN to one year,

- According to published political events, the US-fat cats would rather deal with criminals as Carter's Sadat who was announced by Carter to the US-GM as the prince of peace (portrait A, in a court trial for the assassination of Amin Othman) or a bestial individuals as Haj-Obama's appointee, the imbecile Mursi (portrait B fiddles his penis while meeting Australian Prime Minster), rather than dealing with a popularly elected Sissi post the absolute rejection of Mursi (portrait C). The 2013 election of Sissi and 1919 of Zagloul as a president and prime minster respectively were indicative of the Egyptians' absolute rejection to the historic principles and the long range implications of religious labelling, British and US meddling with Egypt's political court. Ultimately, Sadat's 1981 assassination and the 2013 popular removal of Pinocchio, Mursi, and the concomitant dismantling of $\mathbf{M B}$ thugs necessitated parallel tailoring of the occupant of the White House. This frequent tailoring reflected quantitatively on the deteriorating calibre of Conservatives who succeeded Carter and Haj-Obama; that is Reagan (bedtime for Bonzo) and Trump (the most degrading Maître d'hôtel) respectively. This dark political soup is rather indicative to the bankruptcy of the chefs of establishment's kitchen. The outcome is: what was palatable to Mr. Hempher and TE Lawrence's bedouins is distasteful to the cultured Egyptians. Nonetheless, Sadat and Carter became the armdealers presidents who supplied the Afghani militants with Soviet arms. In brief, the bible waving Carter was a well-tailored individual to camarera the Middle Eastern $\boldsymbol{M B}$, e.g., gift-wrapping Cyprus to the Turks on August 18, 1974. Later the Afghani fundamentalists were the US-proxy militia to dismantle Yugoslavia, Iraq and Syria and topple Nasser's-clown Gadhafi. Currently, both, the nomadic and Afghani Wahhabis are recruited by Erdogan to domesticate Libya and needle Armenia. In effect, the current political whirlwind and costly agitations in Libya and the Middle East are the political yield of the immature and naïve consequences of the ill-calculated gamble of colonel Nasser's coup in Libya in favor of Gadhafi and Carter's support of Sadat respectively,

- $\quad$ Almost a year prior to the popular demand of Mursi's removal from the presidential office, General Sissi called on all public figures with different political agendas including the mentally dry Mursi to a round table discussion to iron differences in favor of a working formula to salvage Egypt. All agreed except for for the typically arrogant $\boldsymbol{M B}$ narcissist, Mursi, and

- Sissi was overwhelmingly elected to preside over an economically bankrupt country (wars of 1948, 56, 67 and 73) whose sovereignty was dominated by the fat cats and thousands of years of a societally ripped nation according to its religious divides (the readers may conclude a specific understanding of said document), and the exponentially multiplying populace is afflicted with a range of tropical diseases and hepatitis C-4b and intoxicated banks of the River Nile with plastics and dead animals. However, considering the prevailing threat of various ferments of dogmatic militancy, in 4-years he managed to steer the nation to social, economic and political stability. In peace, a second Suez-Canal was dug in a year time without July 1956 immature-outbursts of colloquialism which precipitated the October 29, 1956 war. The comedy is while Nasser was touring the nation revelling in an imaginary hallucination; the so-called 1956 victory over the tripartite aggression, the state of Israel got a precious gift from France, a nuclear reactor. Thus, became the Middle Eastern democracy with a nuclear fang.

The Facts Are Overwhelming: the last several years of Sadat and Mubarak's presidencies, Egypt witnessed a devastating proliferation of plastics' accumulations without serious measures of recycling. Visualize the drastic environmental erosion in Alexandria's main source of potable water; that is the Mahmoudiyah canal 1950 versus the Mahmoudiyah canal 2015? Concomitantly, the flamboyant rhetoric of the dogmatically most radical Wahhabi, Sheikh MM El Sha'arawi, induced the exponential growth of Alexandria's $\sim 350000$ populace to $\sim 5$ million without innovations in (a) adequate extraction of novel natural resources and (b) recycling of plastic waste.

Worldwide, humans became addicted to this indestructible material; plastics. Over 300 million tons of plastic objects are manufactured every year, 50\% of which is for a single-use purposes. Refuse of plastics utilized for just few moments and discarded would pollute the planet for at least several hundred years. More than 8 million tons of plastic is dumped into oceans every year. As a result, $\sim 90 \%$ of seabirds have plastic in their guts.

Furthermore, plastic debris is damaging fisheries and tourism, kills and injures a wide range of marine life, has the capacity to transport potentially harmful and invasive chemicals and microplastics to animals and human. According to Dr. R Thompson, 
School of Marine Science and Engineering Plymouth University, entanglement in and ingestion of marine debris by marine animals has increased by $40 \%$ in the last decade.

\section{In conclusion to the Introduction}

Counting on the popular support of his person and considering the societal texture of the land is tilled with the pus of both; the British Wahhabi implants of Hassan el Banna and the US- engineered 1952-coup officers; it would have been easier to Sissi to govern the nation according to the previous corrupt models, Sadat, Mubarak and Mursi. But his distinct and elevated ethics ushered the nation into a totally different course that is suggestive of the 1919 mass revolution of the Egyptians which actualized the reform of the Wafd Liberal Party steered by our Egyptian Vladimir Lenin; Saad Zaghloul.
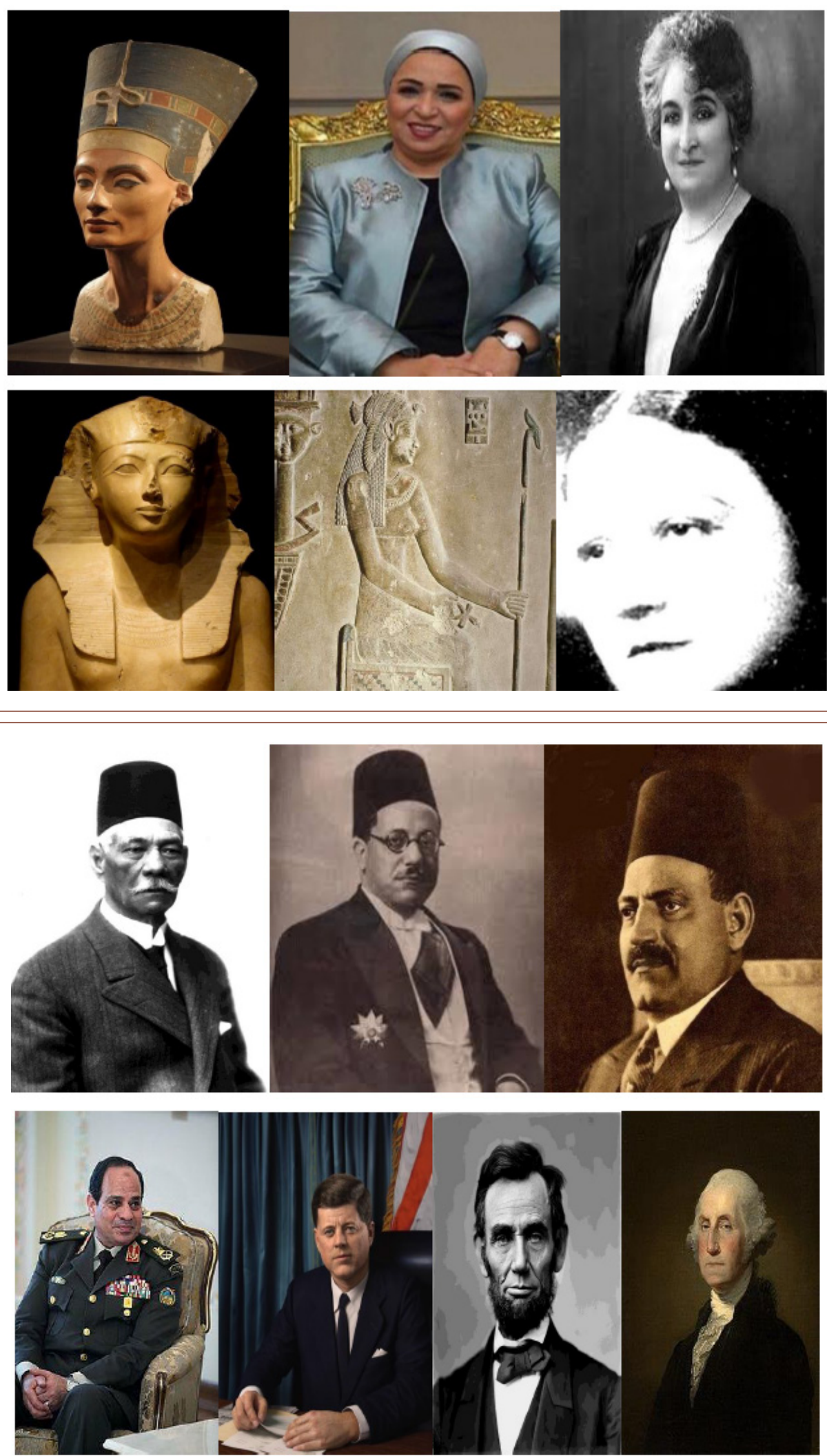
Rationally, the democratically elected president Sissi choose the road to the second awakening of Egypt to modernity. That is to eliminate the weeds and the grey areas entrenched into Egypt's soul. It took from him about an hour delay to reach the presidential place but decided on an evolutionary course of action which healed the 1400- years wounds of the minority. On way from the airport to the Cathedral on Jan 6, 2015 Sissi congratulated the Copts celebrating Christmas: "Let no one say, 'What kind of Egyptian are you? It's not right to call each other anything but 'the
Egyptians.' We must only be Egyptians." Few years later he ordered the construction of a massive Cathedral and a Mosque within the limits of the space allocated to establish a new capital city for Egypt. With distinctness; Sissi graciously took advantage of a hopelessly deteriorating situation to mend the dogmatic psyche of the nations and renew its resources. Regardless of the Covid-19's precipitation of an international economic blunt, in a humane spirits of a reformer, Sissi has sharpened the states' teeth to tackle the issue of the dispossessed and homeless Egyptians.

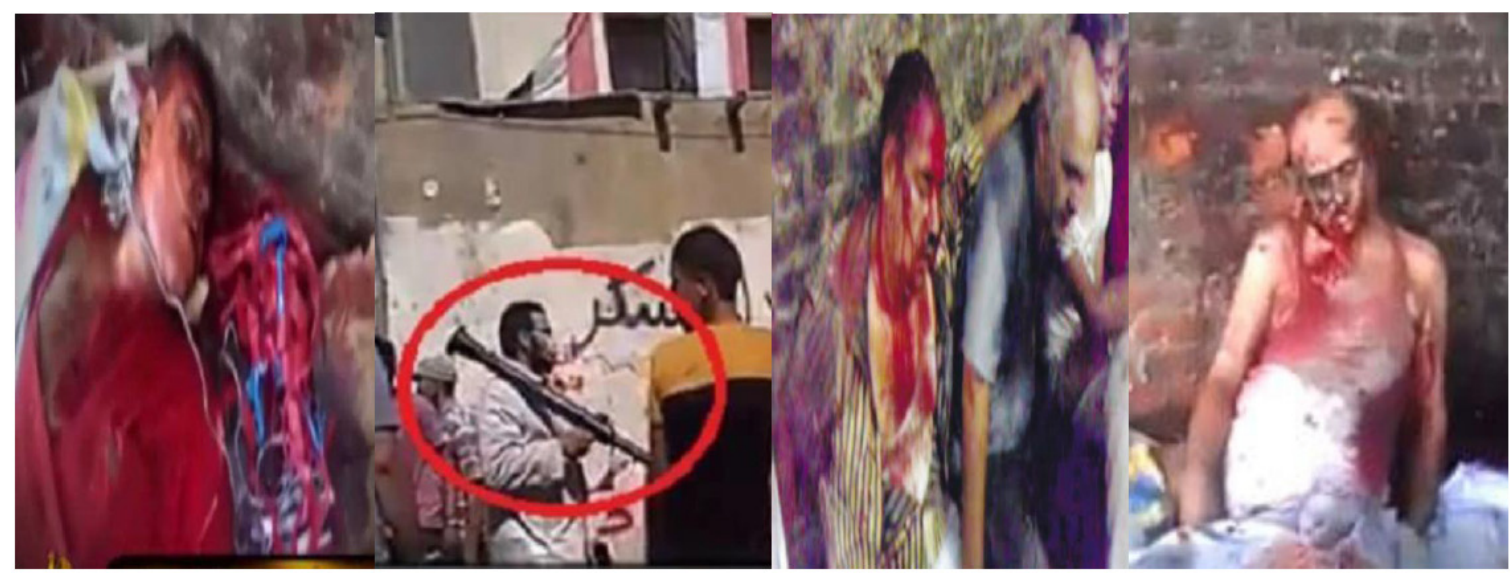

Civilian victims harvested by $\boldsymbol{M B}$, Kerdasah 2013. Note shoulder carried weaponry by $\boldsymbol{M B}$ militant.

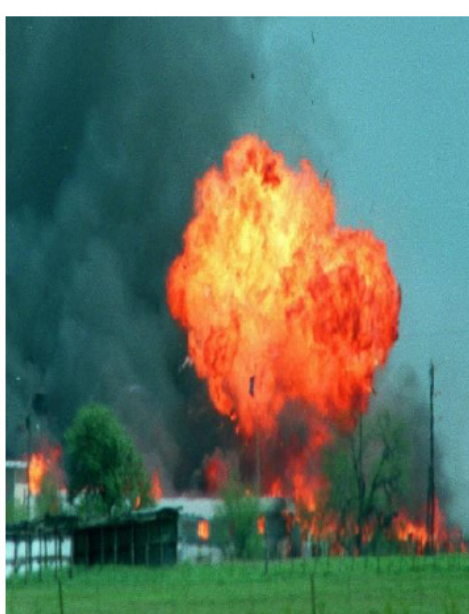

76 Branch Davidians were killed in Waco siege, 1993

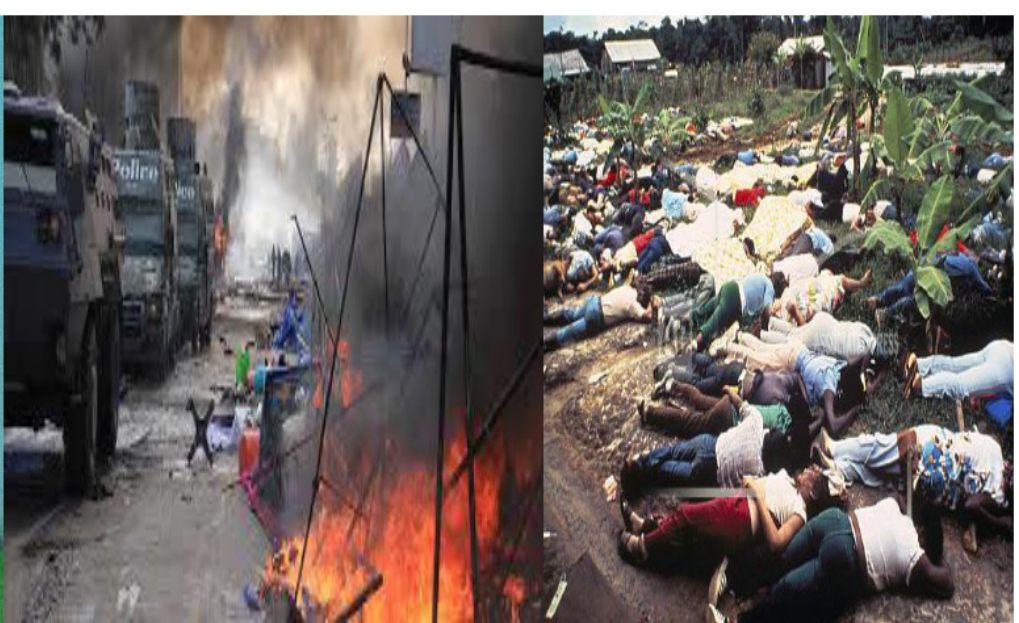

Rabaa Al Adaweyah, 2013
918 Individuals died in Jonestown, 1978

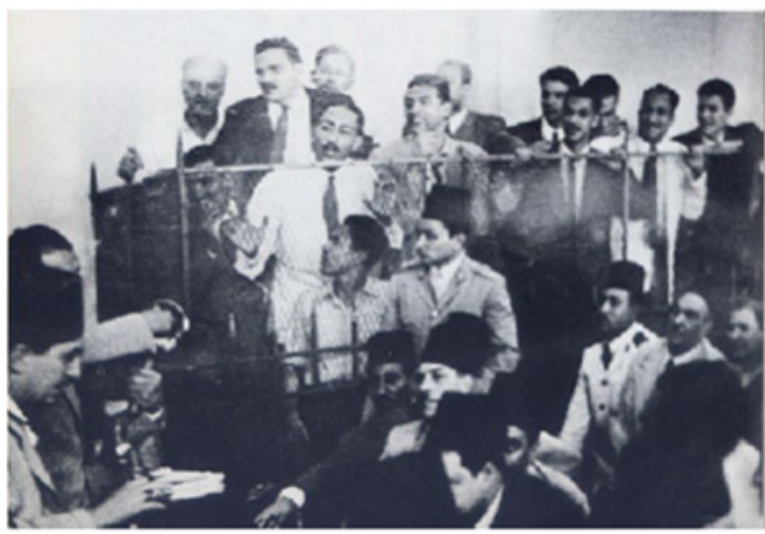

Portrait A: Sadat's Court trial, association of Amin Othman, 1946

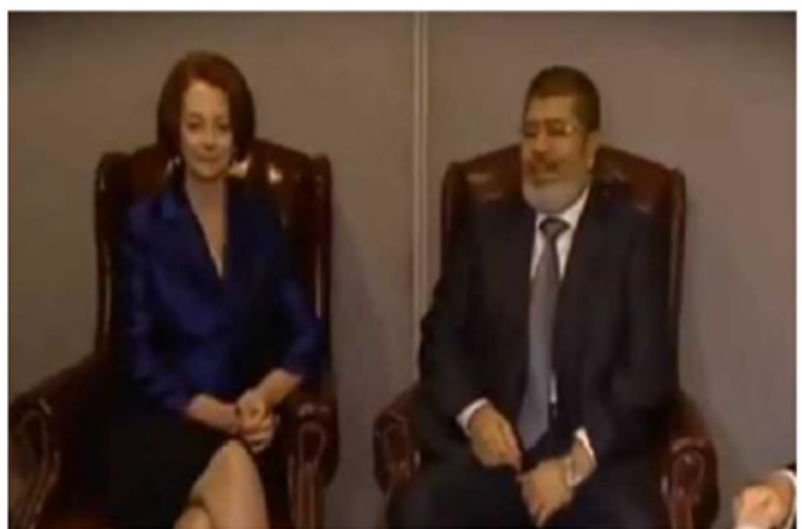

Portrait B: Mursi's manipulating his penis in public, 2012 


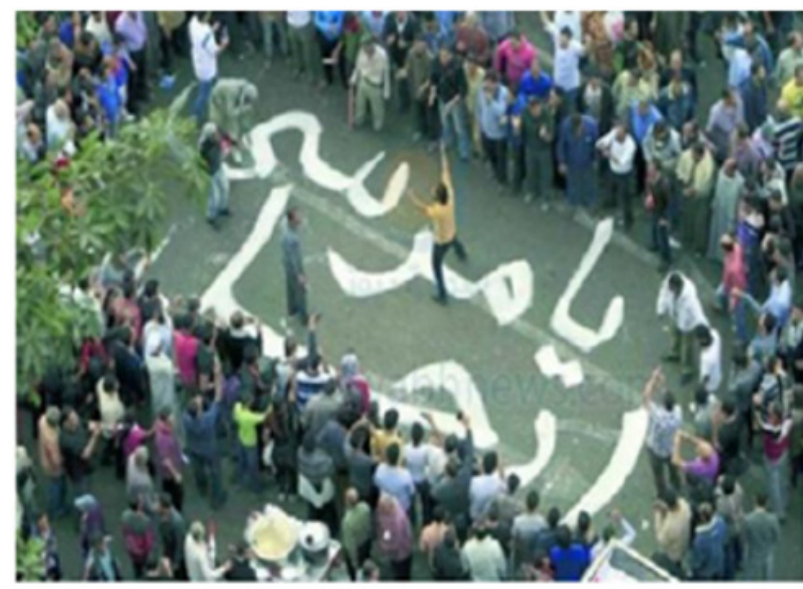

Portrait C: Egyptian revolution 2013

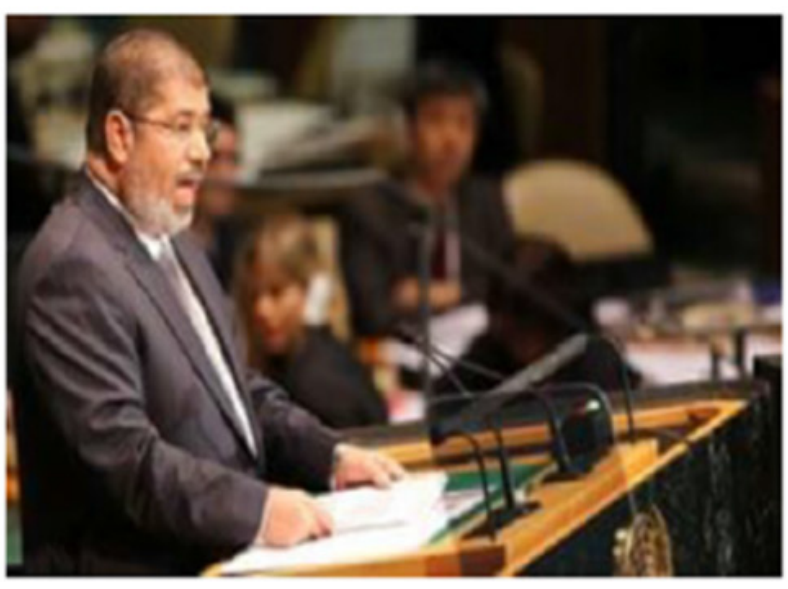

Portrait D: US-arranged Mursi's 2012 Hosanna at the UN
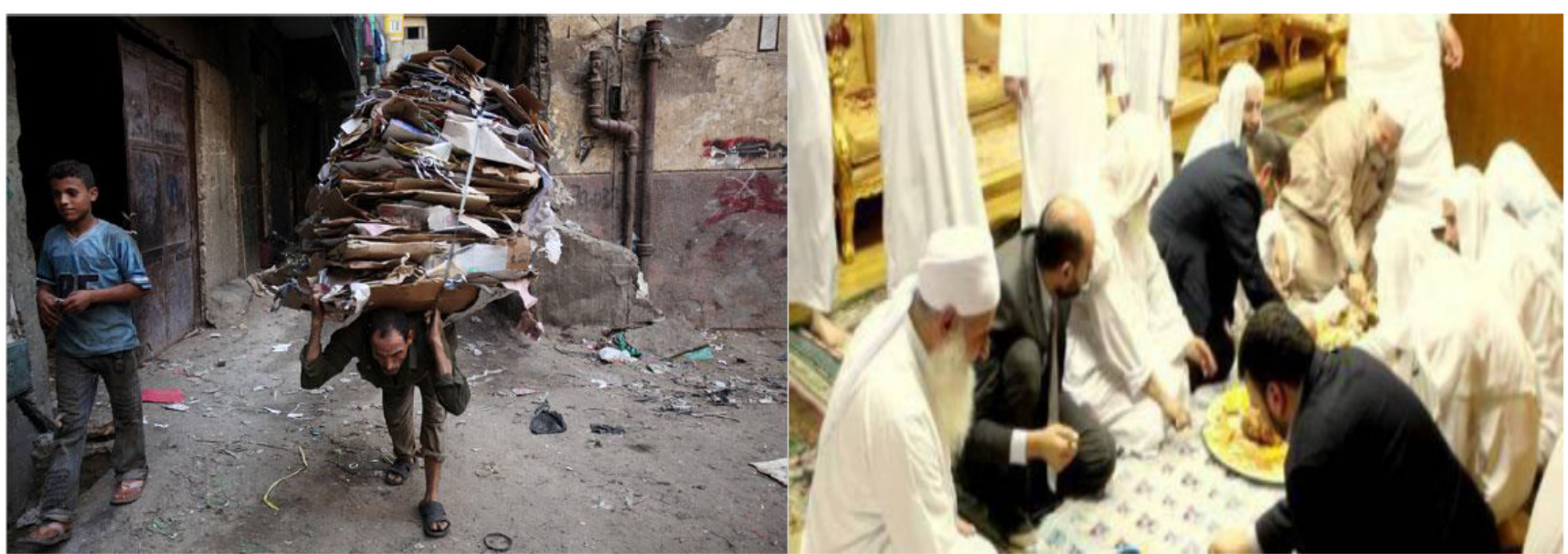

While Egyptian mass was atraved and cohabitating domesticated animals, floor stretched Mursi was dining with his $\mathbf{M B}$ governing elite at the presidential palace.

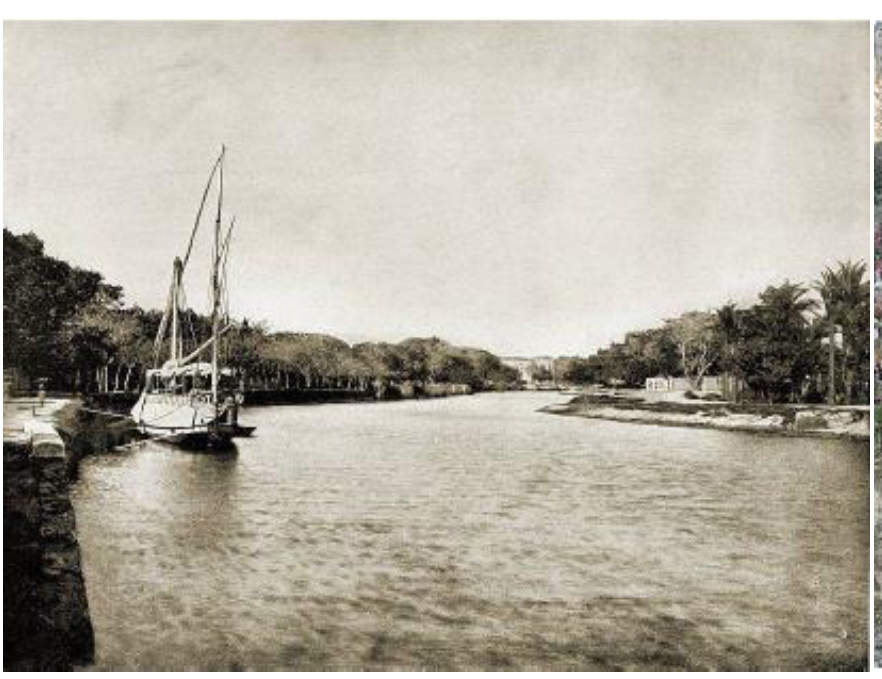

Mahmoudiyah canal-Alexandria 1950.

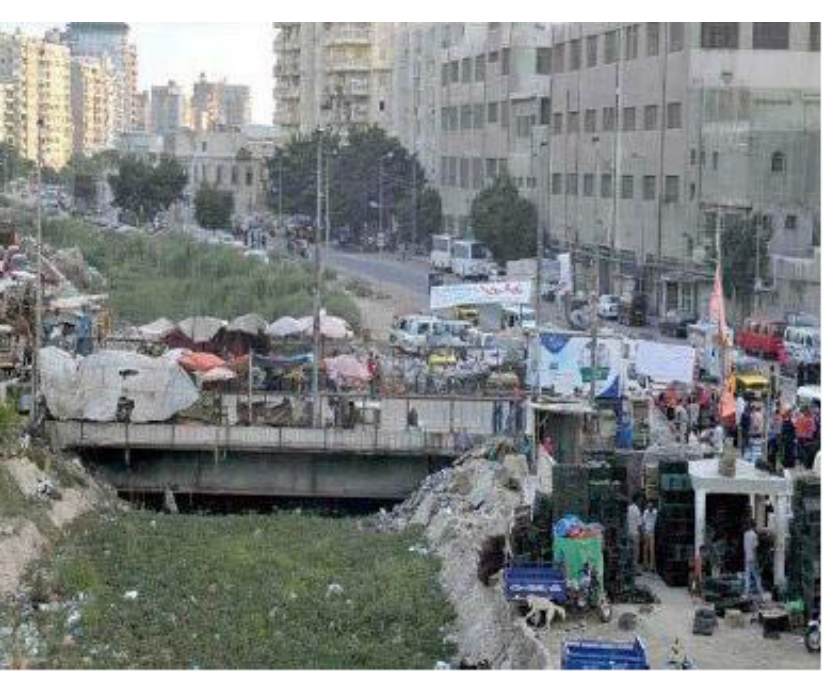

Mahmoudiyah canal 2015 


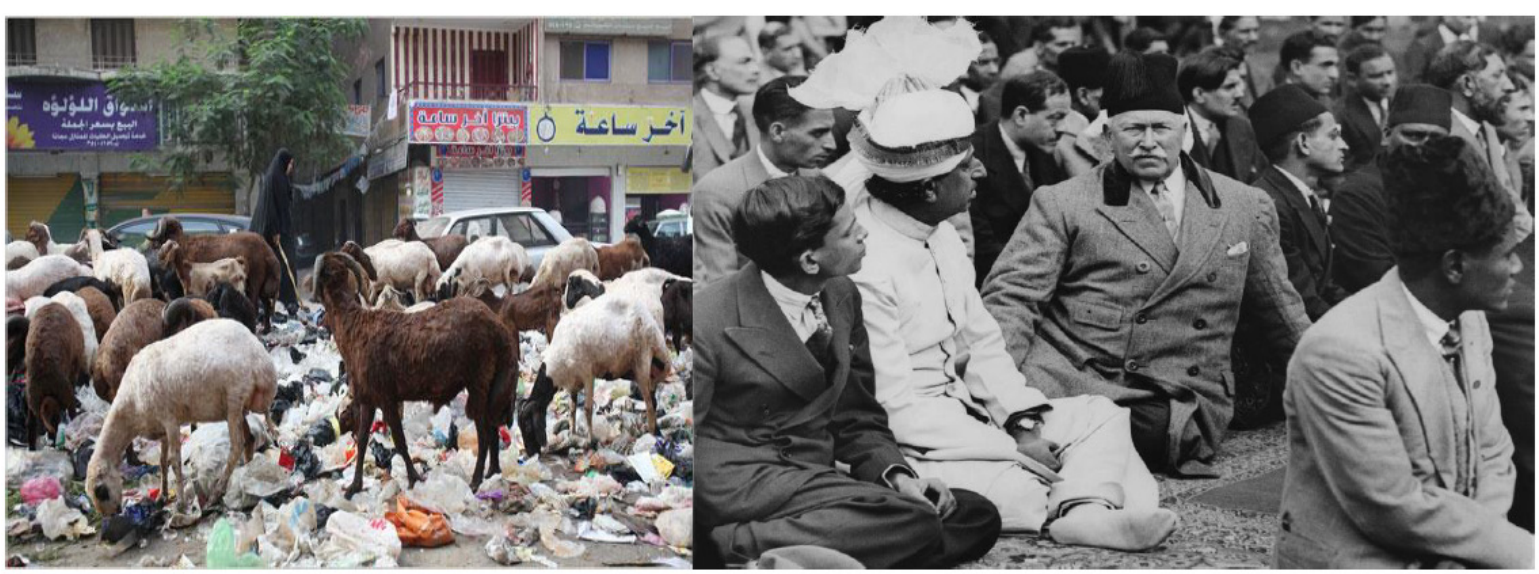

Domesticated animals are roaming city streets, Egypt. Sheikh R. al-Farooq (formerly R Allanson-Winn, $5^{\text {th }}$ Baron Headley) celebrating Eid alAdha outside the Shah Jahan Mosque in Woking.
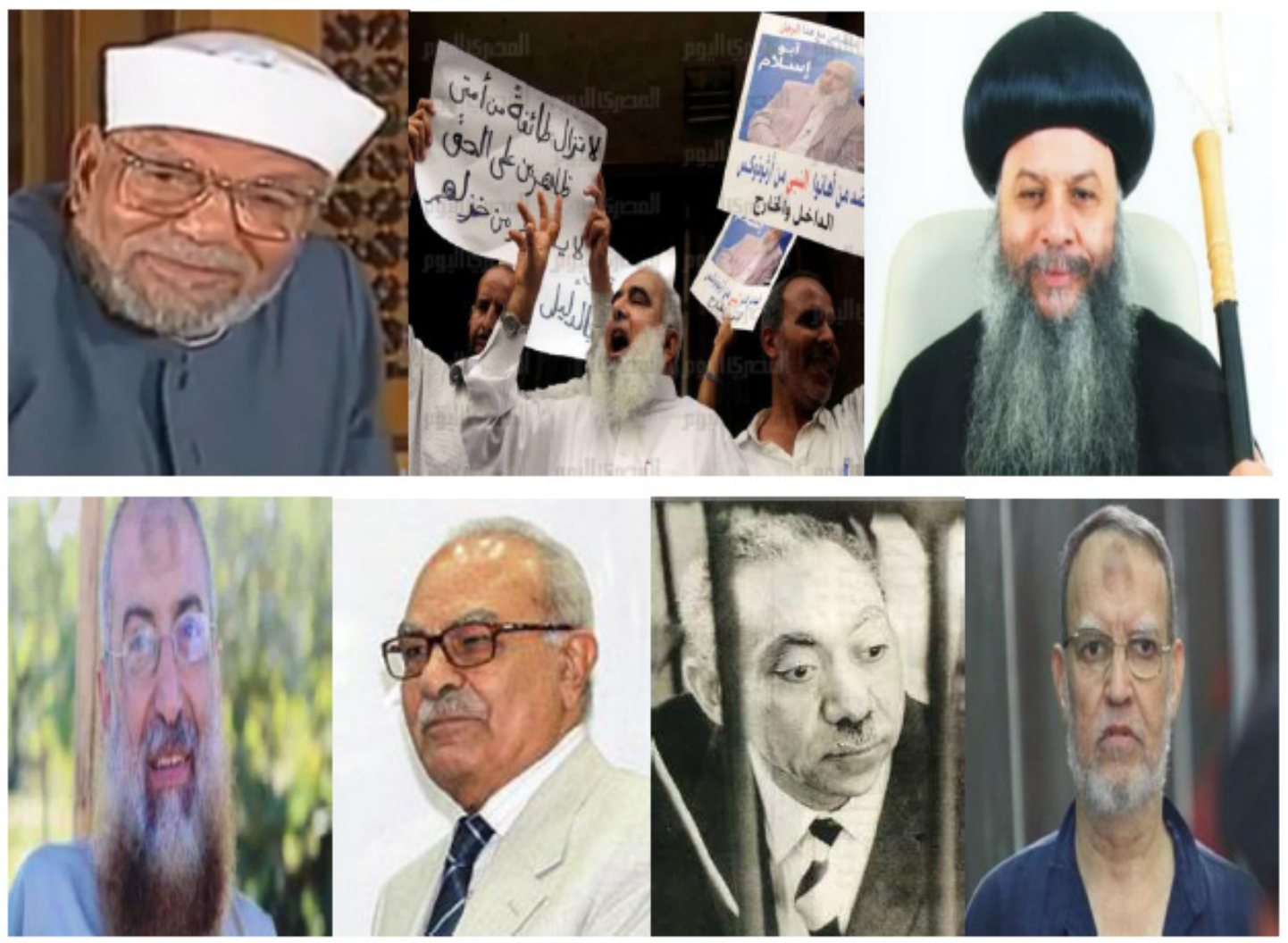

The Unholy Alliance of Mental Bankruptcy

\section{Introduction}

The subject we are tackling is rather controversial to many. However prudently and soberly, we concisely detailed the causative factors behind the genesis of environmental malaise and human psychological aberrations. This is to scientifically visualize preventive means and recovery of current environmental acute devastations, if possible at all? Theology has been extensively factored in equilibrium with historical events and environmental vigor (1). The Persian philosopher SH Nassr laid the foundation for this pivotal link saying "The environmental crisis is fundamentally a crisis of values. And that religion is being a primary source of values in any culture; we are thus implicated in the decisions human make regarding the environment". In Christianity, culture and nature are the same (Davis 1994:31). Yeshua gave His followers a jurisdiction over nature. Alas, Western Christians have abused and depleted nature's available wealth and resources for all to the advantage of the very few fat-cats, to a point of no return. In Islam, Allah reduced humans' equilibrium to a simple equation, i.e., the unconditional support the believers versus taming the unbelievers, denoted dhimmi-infidels/ Mushrikoun. And here is the hinge deployed as of Napoleon Bonaparte's campaign to conquer Egypt (1769 - 1821) to H Clinton-Obama's disastrous cowboy adventure, the 2012 Arab Spring. Vis-à-vis the bombast I-in-C, Napoleon's educated edict to his soldiers was the alcoholic flavor of the ale brewing in Europe as of 1671, Leibniz's Egypt plan: 
"The people amongst whom we are going to live are Mahometans. The first article of their faith is this: 'There is but one God and Mahomet is His prophet.' Do not contradict them. Behave to them as you behaved to the Jews - to the Italians. Pay respect to their muftis and their imaums, as you did to the rabbis and the bishops. Extend to the ceremonies prescribed by the Koran and the mosques the same toleration which you showed to the synagogues, to the religion of Moses and of Jesus Christ", and the Napoleonic Proclamation to the Egyptians:

"People of Egypt: You will be told by our enemies, that I am come to destroy your religion. Believe them not. Tell them that I am come to restore your rights, punish your usurpers, and raise the true worship of Mahomet. Tell them that I venerate more than do the Mamelukes, God, His prophet, and the Koran. Tell them that all men are equal in the sight of God; that wisdom, talents, and virtue alone constitute the difference between them. And what are the virtues which distinguish the Mamelukes, that entitle them to appropriate all the enjoyments of life to themselves? If Egypt is their farm, let them show their lease, from God, by which they hold it. Is there a fine estate? It belongs to the Mamelukes. Is there a beautiful slave, a fine horse, a good house? All belong to the Mamelukes. But God is just and merciful, and He hath ordained that the Empire of the Mamelukes shall come to an end. Thrice happy those who shall side with us; they shall prosper in their fortune and their rank. Happy they who shall be neutral; they will have time to become acquainted with us and will range themselves upon our side. But woe, threefold woe, to those who shall arm for the Mamelukes and fight against us! For them there will be no hope; they shall perish."
At his young age, the Napoleonic compositions above to his troops and the Egyptians are a masterpiece of diplomacy that is absolutely alien to the current triple-aged Maître d'hôtel's SASGF. To his absolute credit, Napoleons' far sighted vision was the first cognizance of Middle Eastern maladies; the Mamelukes' and Turkic's abuse of Egypt. In three years, Napoleons' reform improved the social status of Egypt vis-à-vis the US past 70 years pomposity as of Eisenhower's presidency to the current melancholic commercialization of the Chinese virus, Covid-19. Worse, pollution is portrayed as Chines scheme to derail the productivity of the best nation of the world. Reckless political weaving is anticipated to melt the Middle East in a nuclear holocaust on the account of manipulating the Shi'a - Sunni conflict. While the predecessors, the war president and dad-the spoke have precipitated an acute degradation to the Middle Eastern environment, e.g., Kuwaiti oil burning, residues of uranium enriched weaponry, the slaying of ethics at Abou Ghraib's together with waves of devastated refugees of minorities seeking asylum in Europe and the USA. As the Jews of 1938-39, these asylum-seeking minorities are denied of the least protective measures. Worse, the I-in-C is building walls and at the borders, estranged children of their families are cruelly locked in cages as of Haj-Obama's presidency. Although, TV cosmetics and commercialization introduce these chaps to the voters as two different political entities, once either in power, the elected would manage the destitute according to a settled framework sketched by the food cooperatives, pharmaceutical multinationals, the USPB and MIC. The ultimate ends are the insolvency of the working class and the absolute hegemony on natural resources, e.g., fields of crude oil, water resources and minerals, in favor of the few fat-cats.
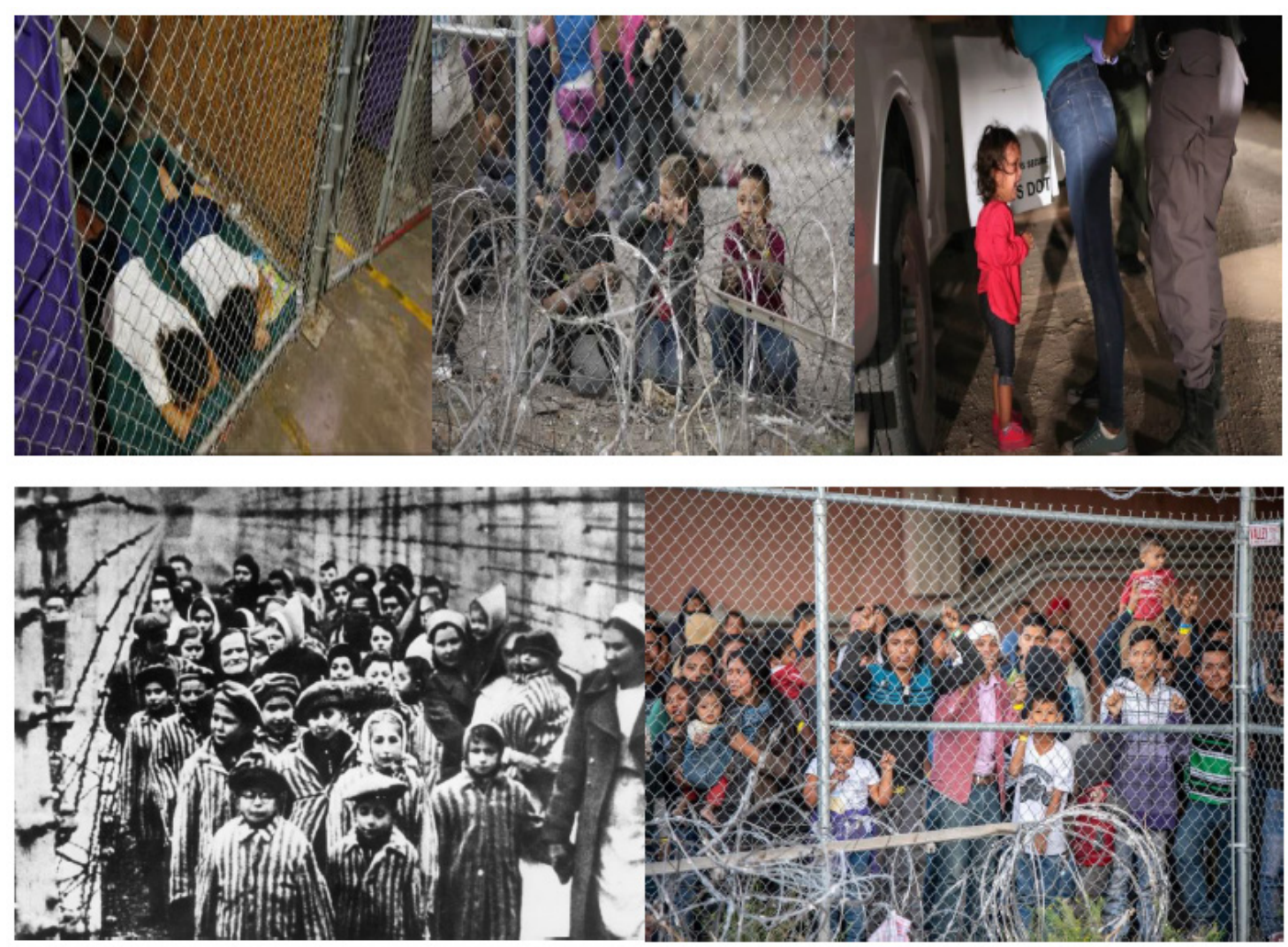

Asylum seekers detained in cages and US-Mexican borders 
Interestingly, according to the available data (Data, Figures 112); theological interpretations may conclude the current failure of science and the malaise of rationalism to account for the bankrupt linguistics, philosophical and historical antiquities leading to the breakdown of universal societal cohesion, viz., Covid-19, refugees fleeing to Europe and the USA, Abu-Ghraib, etc. All of which may precede mental cirrhosis of intellectualism, eventually prompting the denial of environmental necrosis.

Thus, this presentation is an attempt to delve into the void inbetween reckless agitations of dogmatism as in the mapping of the Middle East according to Hempher, GM Bell and TE Lawrence and the inevitability of exporting de novo subtypes of viralbacterial diseases and dogmatic-psychological aberrations to the industrialized world. Most recently the UN published some observations [2] in support of our toil pertaining to documenting the impact of homelessness, chronic poverty and acute scarcity of sanitation on the potential evolution of second generation bacterial and viral breeds, pollution and environmental erosion [2-5]. It is our contention, physical organic chemists' critique of the available data together with trends of abrupt societal mental vagaries pertaining to a specific location plagued with proliferating nests of crammed homelessness, would yield different perspectives on handling the ensuing environmental erosion and pollution.

Here is our thesis: characteristically the sole mental diet of the occupants of these filthy locations is confined within the black box of the sayings of the $1400 \mathrm{y}$ old pious elders. Thus, to circumvent the dogmatic feud-induced environmental erosion, it is inevitable to provide medication, healthy meals and education, in-depth psychological scanning to the occupants of these domains. That is, to financially provide for the physically and psychologically crippled victims of societal characterization, i.e., communalism would ultimately nullify the expected ramifications of societal discontents and unnecessary wars with a neighbouring country. On the other hand, with all the muscle flexing and mental vomiting "we are the first nation in .... and ..." the SASGF's politicians failed and are unable to realize the MIC-financial gains of evoking Middle Eastern wars are short lived. On the long run, these gains are consumed by the burden of sheltering a well calculated Wahhabis infiltration within the ranks of the desperate escapees seeking refuge and accommodation within the Western mosaic. Thus, the mentally unripe cowboys catalyzed the actualization of the antithesis to the 1671 prescription, the typically European Leibniz's plan. Visualise the devastatingly different details of Napoleonic advance into Egypt vis-à-vis the cowboys' invasion of Iraq and Afghanistan.

Accordingly, quenching all reasons for wars and conflicts to evade world-wide prospects of environmental erosion and would provide peaceful formulae to control both environmental erosion and dogmatic-mental aberrations. This task should be the prime concern rather than the typical practice of alleviating local dogmatic inflammations by say the "Arab Spring's recycling of Mr. Hempher's Wahhabism and dogmatic emotions of the illiterate nomads". In effect, reviewing the humanitarian and environmental causalities perpetuated by the USA is an urgent call to physical organic chemists to take the mandatory task of natures' revitalization.

\section{Dogmatic induction of environmental ruin}

According to data; armed belligerencies have pointed impacts on the environment and mental stability of the vulnerable. Wars are destructive to the socio-environment, as barbarism at the war fields of death prompts massive human losses and environmental ruins, e.g., agent orange was extensively applied in Vietnam to eliminate forest cover and destroy plant crops, Hiroshima and Nagasaki's devastations to the anthropogenic climatic changes, together with persistent pollution, physical deformation of 3rd and 4 th generations of the occupants together with acute resource depletion, among other many environmental impacts.

To introduce the reader to our hypothesis of the dominant mental-poverty and psychological aberrations, viz., necrophilia, pedophilia which were extrapolated to surreal dogmatic dictates. In times of urgent necessities; males are allowed to copulate with their mothers, sisters and younger brothers. To enlighten on this issue according to a different perspective, it is conceivable to shed light on the Egyptian obsession with the concept of the "after-life" (Figure 4). At the appropriate circumstance, this passion turns into fatal mental deprivation, e.g., 2013 assassination of a prominent Shiite cleric Hassan ben Shahata in the village of Zawyat abu Musallam by rioting 3000 Salafist [6]. This particular incidents is indicative of the same genetic "mob-tendency and street justice" of the rioting 3000 Salafist is carried from their Alexandrian ancestors who murdered Hypatia of Arcadius [7] on 415 AD, a Neoplatonist philosopher who disputed the principles of their utopia (Figure 4).

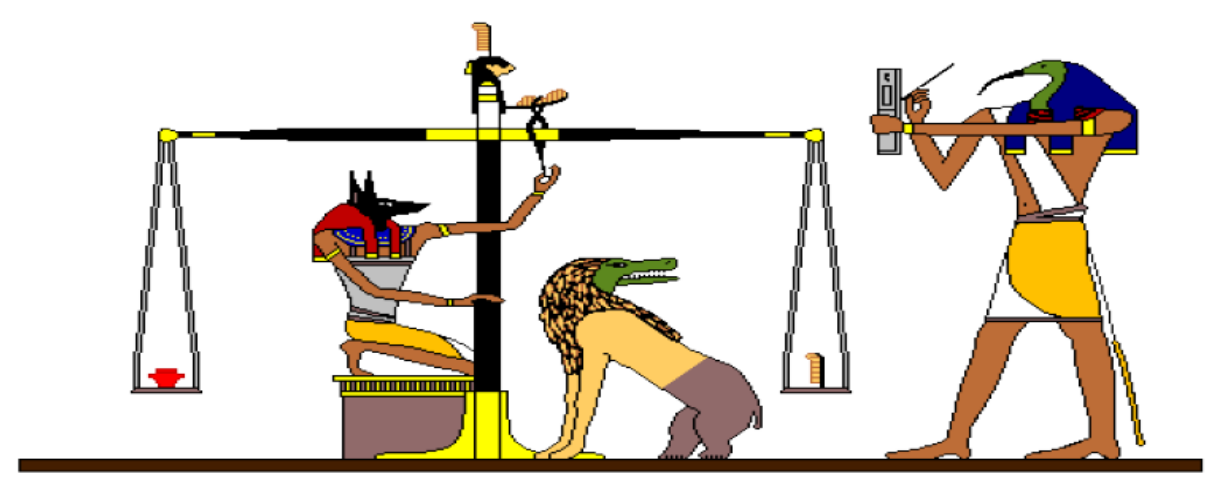

Majority of mythologists concur; the Ancient Egyptian Deity Anubis is the premier architects of the mythological concept of weighing the heart of a diseased as a pointer to his/her deeds in life. However, fine details differed. 
For two reasons, the Ancient Egyptians endeavored harmonious specificities with made-to-measure mystical figures to safeguard, (i) a bountiful seasonal extraction of natural wealth, mainly agricultural and RN's produce and (ii) a compensating "after-life" in proportion to their daily deeds. Deity Anubis was architected to decide on the fate of the deceased's soul according to the weight of his/her heart. At that distant time, many deities cohabitated the Egyptian rational. This deities' cohabitation was interlaced to entertain the unique Egyptian farmers' specificities to the essentials and abate daily hardships. It was not until Pharaoh Akhenaten conceptualized the first rhythm to monotheism [8], duel erupted between the clergy of Akhenaten's monotheism and the adherents to the polytheism of Amun-Ra and the Osiris. As per S Freud's assumption; the historical conclusion to this duel was Akhenaten's clergy crossing of the red sea and taking refuge into the Sanai desert and the assassination of his successor, Pharaoh Tutankhamun. Currently, it is as it was at the old times, the greed of the Egyptian clergy had no limits to the attainment of the absolute domination of the nation and pacify the Egyptian mass to their whims, e.g., the successor Tutankhaten changed his name to Tutankhamun to appease and evade the wrath of the powerful Amun-Ra clergy. Nonetheless, it did not bode well for him as opposing clergy assassinated him at young age [9], thus, germinated the eclipse of the nation. To salvage the nation, General Ra-mosa was prompted to take the helm of a hopelessly disintegrating nation to rebuild a glorious dynasty of science and arts. As much General Sissi did in 2013 [10].

\section{Hypothesis: Re-Akhenatenism at Anno Domini}

Our main drive is to tackle Akhenaten's monotheistic theology and its impact on the societal arrays at the time of its incipience and beyond. Akhenaten was an Ancient Egyptian Pharaoh of the $18^{\text {th }}$ dynasty whose original name was Amenhotep IV. Amenhotep is a hieroglyphic for "Amon Is Satisfied", that is indicative of his initial adherence to the prevailing deity Amon. Although, the genius of the Egyptian composition of the earliest Monotheism incited the collapse of an outstanding dynasty, it was scientifically recalibrated by Sigmund Freud, in an inspiring thesis: Moses and Monotheism [8]. À la the orthodoxy of Sigmund Freud's psychoanalysis, we are delving into the quest of the conceptual evolution of the Paranormal according to the typical critique of physical-organic chemist. Thus, theorizing on the thunderous events of Jerusalem as of Anno Domini 1, Herod murdering the 2 years old and below male children of Bethlehem and close by areas and the burning of Rome $64 \mathrm{AD}$ as well [11]. These events were the climax to the Re-Akhenatenization of the monotheistic core, the Sifrei Torah of the time to its original patterns imbued by Pharaoh Akhenaten. The Egyptians did not waste time, in absolute vigor they reclaimed their doctrinal heritage and until 451 verbalized their specific historical model of the de-novo re-Akhenatenized dogma, that is the Miaphysitism as determinedly labored by Cyril-I of Rakoda on the Byzantine Empire and the Western world. Typically, the Western miscalculation at 450 [12] led to thecollapse of the Mediterranean and southern provinces of the Byzantine Empire in 641, the 1453 fall of Constantinople [13] and the, irretrievable loss of the core of multiple civilizations, viz., Egyptian, Assyrian, Mesopotamian and Persian.

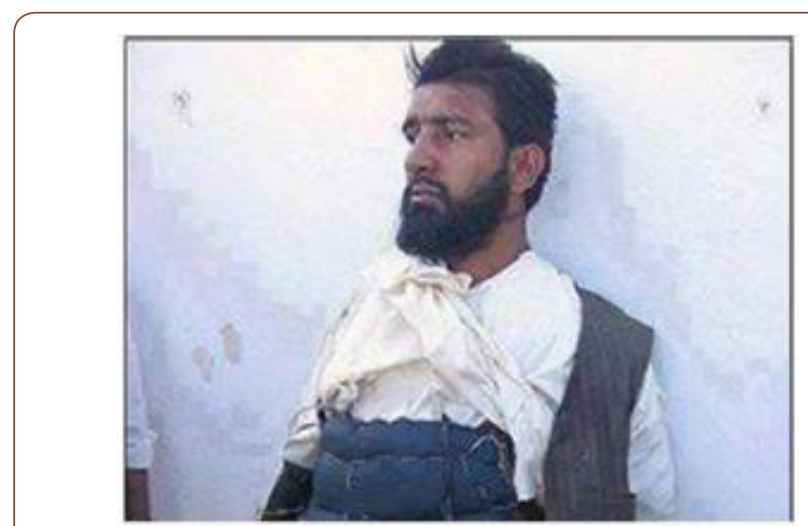

Figure 1a: (http://www.q8yat.com/t1148945.html)

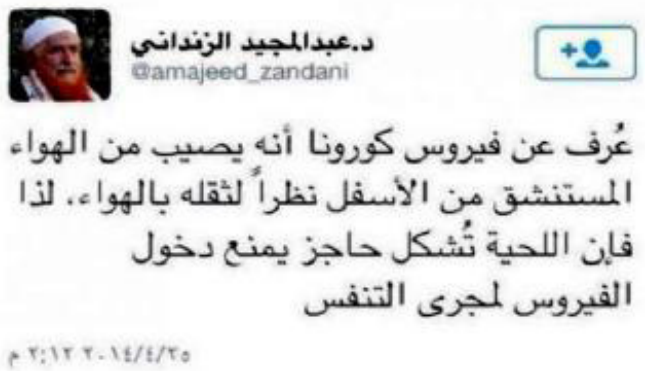

Figure 1b: Salafis' goatee is a protection as filters Covid-19?
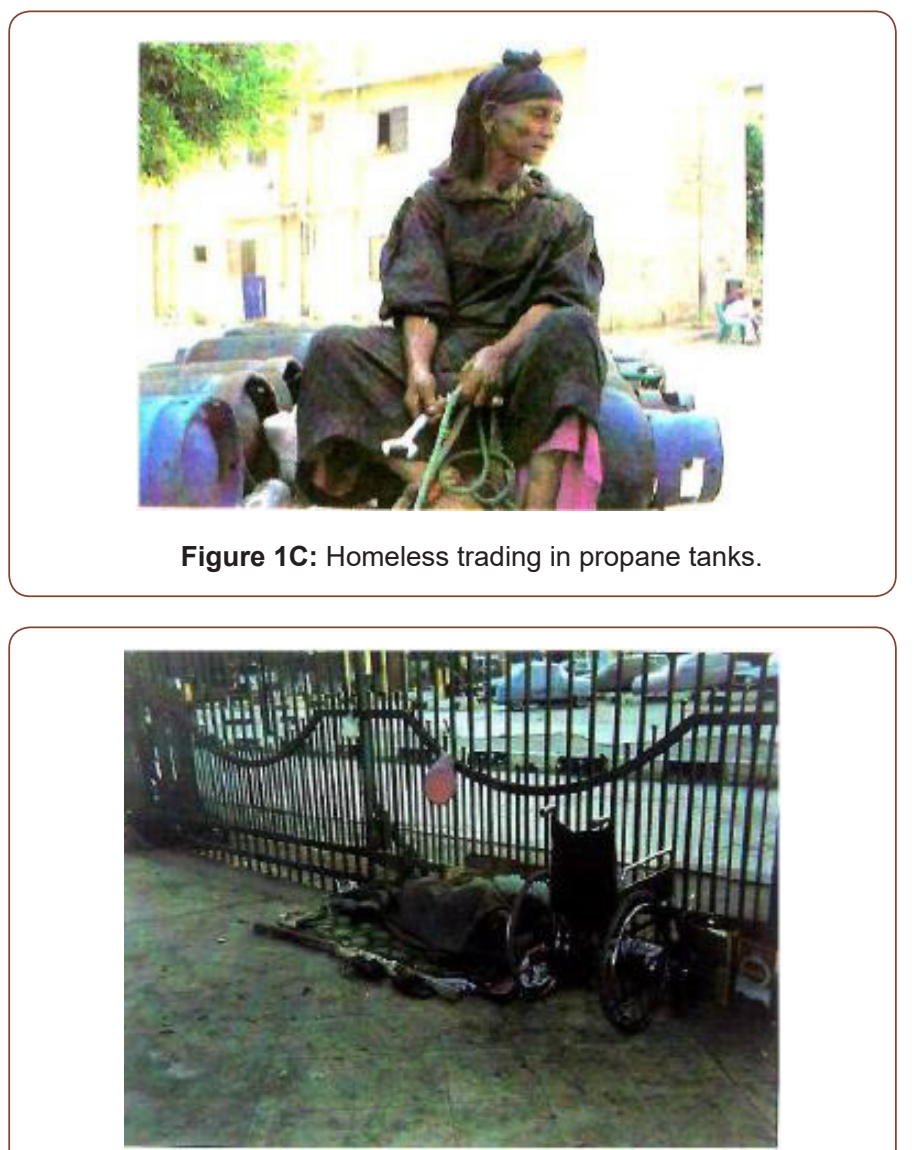

Figure 1d: Homeless at Alexandria train station. 

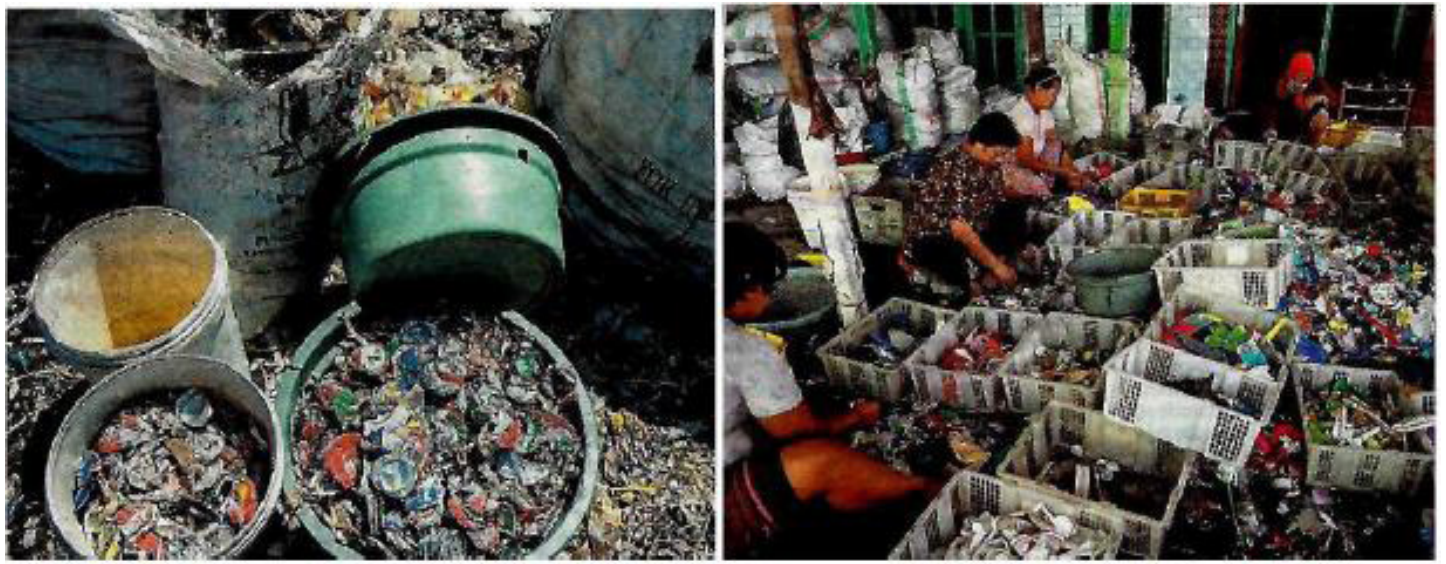

Figure 1e-1f: US-export of plastic refuse to Indonesia.

\section{Retro-Akhenatenism}

According to the societal obligations: the folkloric abundance of linguistic poetry praising the tellers' ancestors or tribes while belittling opponents and other tribes, and the presence of many Ancient Egyptian nuclei of culture and mythologies, Retro-Akhenatenism was hatched. Incidentally, it was the political yearning for the survival of the Israelites which would logically invite many theological queries. Nonetheless, shared orientations necessitated common societal values, e.g., women piety among others. However, both were different from the colourful master pattern of the Ancient Egyptian ladies. Although, it took thousands of years for local monotheistic reflexions to imbed its streams à la corresponding societal terrains, at large; the source will ever remain an Ancient Egyptian Monotheistic deity. Why then wars?

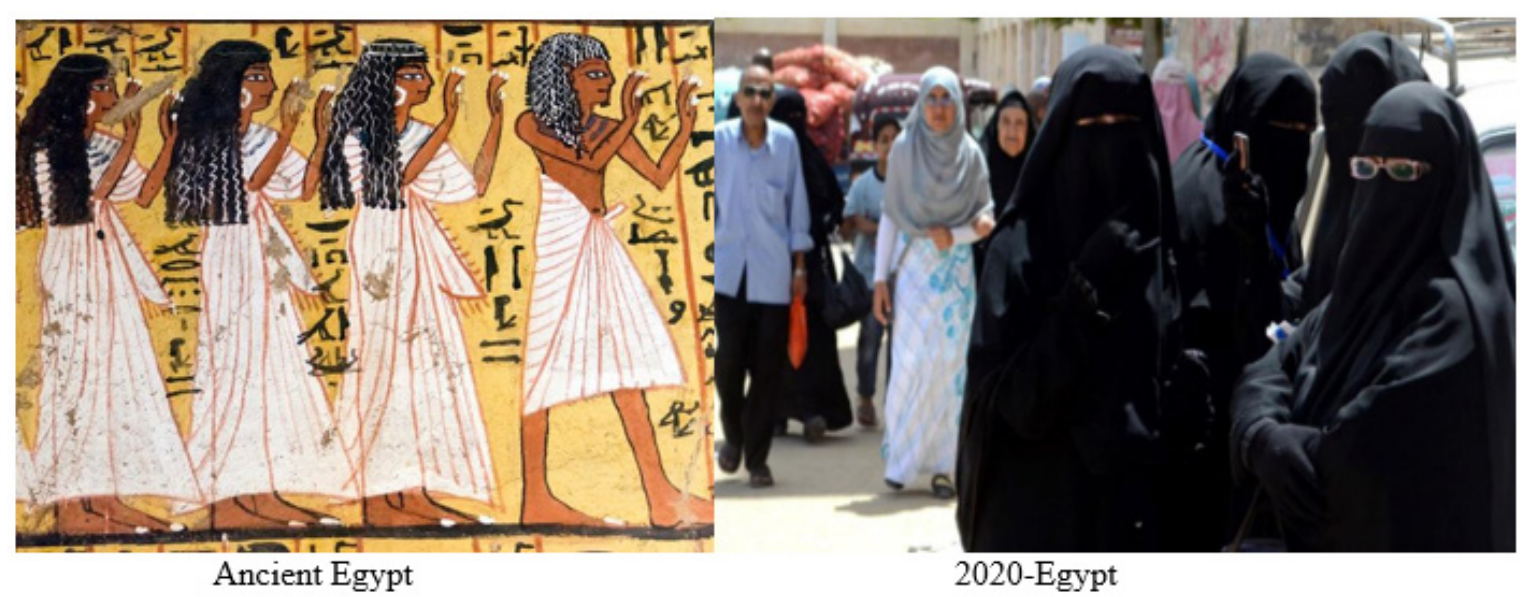

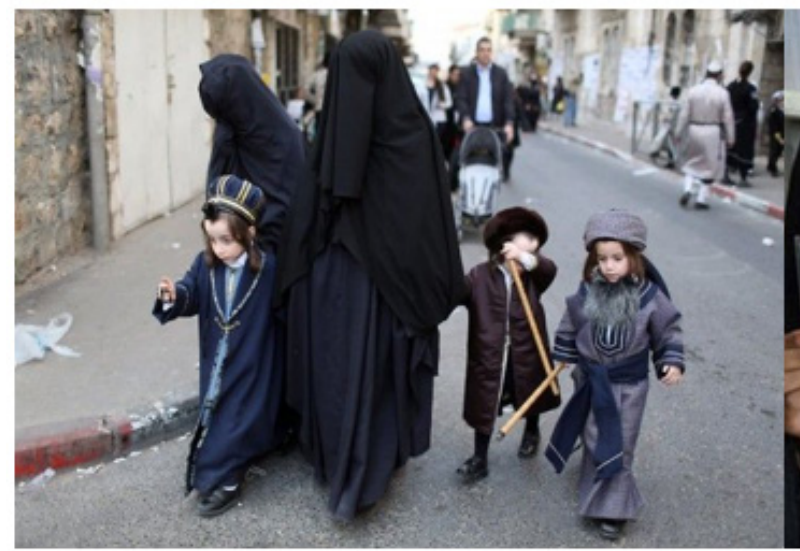

Jerusalem

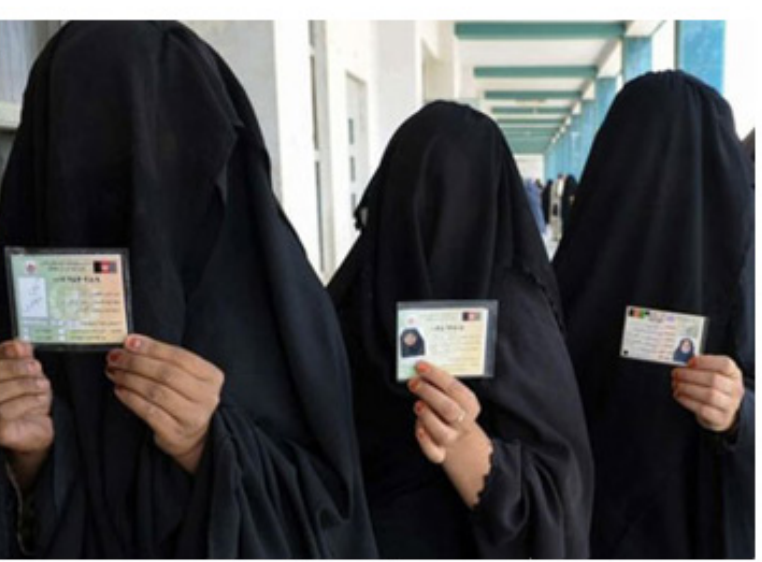

Saudi Arabia
Alas, the dictates of history do not necessarily parallel the idealistic rationalism of the physical organic chemists $v i s-\grave{a}$-vis the kinetics and mechanisms of a specific natural evolution. For the last two thousand years, the Egypt was colonized by many nationals.
However, alien nationals were domesticated and absorbed within the text of the Egyptian farmers. That is the brains and souls of the trespassers were captivated by the Ancient Egyptian mythologies, i.e., Egyptians in all of us. Mechanistically, with some certainty 
Retro-Akhenatenism is a recessive yield whose synthesis was deemed essential to the survival necessities of a besieged minority to the uncompromising attitude of Papal Rome. Although Christians, Papal Rome which was not any different in attitude from the gladiators' Rome to the Israelites' minority, rightly so a defensive mechanism was mandatory. Thus, at the apex of their wisdom, the Jewish religious elite tailored a second major undertaking to secure the cohesion of their folks. Nonetheless, their enterprise delivered a handicapped Retro-Akhenatenism as the milieu of delivery lacked the low and order of the Roman Empire and the prudence of Pontius Pilate. Primarily, the specific dialectic of the novel set of thoughts was centered to negate Yeshua's Crucifixion and primarily the 12's claim of His Ascension on the $3^{\text {rd }}$ day. Thus, the feverish lust of denying His Divinity is attained. Amenably, the prompted Retro-Akhenatenism espoused de novo sharp edges proportional to the harshness and aridity of the nomadic milieu of its incipience. Nonetheless, it coercively flourished within the intellectually-void populace of the adjacent tribes and beyond. By comparison, post 451-Chalcedon, every second Alexandrian was intelligently capable of debating the Nature and Trinity of Yeshua. According the available historical data, the negative impacts of Retro-Akhenatenism surpassed the benefits of negating Yeshua's Crucifixion and Divinity. It is too late to untie the horrific consequences of its theological calamities, specifically Mr. Hempher's brew of Wahhabism is served and happily consumed by many Western politicians as an instantaneous guarantor to their Middle Eastern oil-fields. The socalled victory in Iraq, the 16 y labour in Afghanistan, slaughters in Yemen, Libya and Syria are omen for the collapse of second Rome. A wise Russian eloquently envisaged the Cain and Abel DNAreplication of hatred as the finale mouthed by the Nazi chief: war is eternal and everywhere, it has no beginning and no end, war is life itself. As of 641 until this point of time, they and other nationals are the subject to the wrath of their unfortunate tailoring.

Our thesis may be tailored differently. Considering the DNAevolution of Akhenaten's set of thoughts, it could be hypothesized with some certainty: the last modification was conceptually an intentional self-serving, thus embraced the same pool of thoughts. Primarily, it was tailored as the nemesis of the previous yield, that is the passive Yeshua's Re-Akhenatenism. Unbiased elaboration of available data, it is safe to assume, the two major blunders committed by the unyielding religious elite at the time have failed twice with devastating consequences to its adherents. Although an abyss of $\sim 600 \mathrm{y}$ separated the two events, the rational conclusion is the two groups of fervent religious order shared the same shortsightedness. Considering the obliging rational of Sigmund Freud of a first-class lineage to the Egyptians, said typical clerical's shortsightedness should not be surprising the least.

Below is a supporting visualization of our hypothesis: the dictation of environmental events on the evolution of late RetroAkhenatenism. Most likely, the Amalek are the Turkic; phonetically synonymous with Mamelukes المماليك or العماليث managed to reduce the Egyptian populace $\sim 15$ million in 641 to less than 5 million in 1805. Prior at an earlier frame of time, for the sake of selfpreservation, the early Israelites had to ferociously engage with the
Amalekites which quantitatively modulated their Literature until Yeshua managed to reformat it, i.e., Re-Akhenatenization to its original configuration. According to wars of class struggle and for the sake of preserving the political entity of the Byzantium, Emperor Constantine had to appease his populace. Therefore, declared the de-novo Re-Akhenatenization is the official set of thoughts of the Empire (323 AD). Nevertheless, Constantine-I endeavor failed on the account of two factors, namely;

- $\quad$ by definition, once Re-Akhenatenism became the official religion of the state, various elected prelates to various regions of the empire became state officials. When these religious officers convened in Nicaea-325 and later to harmonize a linguistic definition of faith, they converted their gatherings into arena unambiguously debating the newly acquired Re-Akhenatenism according to specificities of inherited cultures, and

- $\quad$ the transition state of 323 AD victory was dismembered in Calcedon-451 to belligerent localities with different cultures, languages and historical acrimonies; e.g., consider Cyril-I of Alexandria and Nestorious of Antioch. The best description to Calcedon which prompted the first schism; it was the Council of the screaming deaf where nationalism and cultural heritage were the domineering factors rather than spirituality. At the apex of their cacophony, both Leo and Dioscorous-I of Rakoda failed to eye the impending threat of Retro-Akhenatenism.

The privilege to a nonpartisan scrutiny of historical events by physical organic chemist is that we weigh and see it differently. With some certainty, Dioscorous-I of Rakoda utterly failed to palpate the far-reaching political corollaries of the failure at Chalcedon. Neither had he understood the urgency to "religious harmony" among the opposing parts of the Empire. In fairness, his closeness to the governing seat of the Empire, Leo was much better suited to appreciate the urgency of a "political-religious harmony" at this particular time. To reach a general cognizance, Leo had to adapt to an agreeable thesis of faith among the different bishops at the time which happened to be the opposing Nestorian thesis. A subtle scrutiny of Chalcedonian minutes suggests: regardless of all claims of infallibility; by all means, Leo was not aware of the historical and cultural subtlety of the Alexandrians Miaphysitism versus the Assyrian Dualphysitism. But rather intentions were fixated at deposing Dioscorous-I of Rakoda. Obviously, he was lacking the intellect to appreciate the cultural difference that strained Alexandria-Antioch's definitions of deities. But a shrewd politician, in order to excommunicate the pope of Alexandria and assume his title, he naturally enlisted the Nestorian bishops to debar Dioscorous-I. With all Infallibilities, Leo failed to once and for all to rinse his nightmares of the Egyptians. They were everywhere! Occupied the brains and soul of Rome and the Vatican itself, viz., L Gordan-Rastelli, Isis \& Egyptianizing Rome, KMT A Modern Journal of Ancient Egypt, Winter 2020-21, 31:4, 18-31 (the Sphinx Piazza del Popolo and Villa Borghese, Rome and a Sphinx chamber at Emperor Nero's palace in Rome was brought to light after 2,000 years, as well). As much for the sake of political stability, Emperors Constantius II and Valens expired as Arians. 


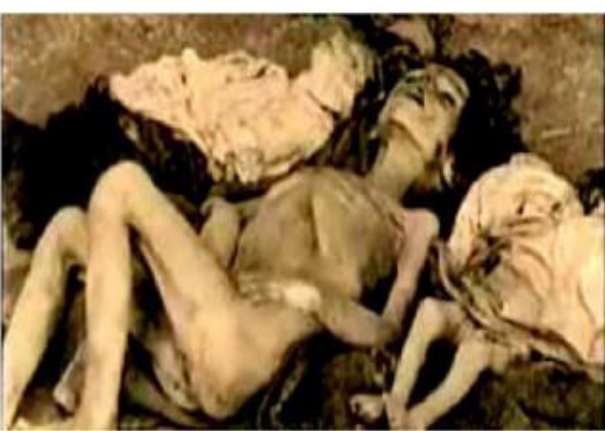

Figure 2a: Turkish Erdoganization of the Armenians

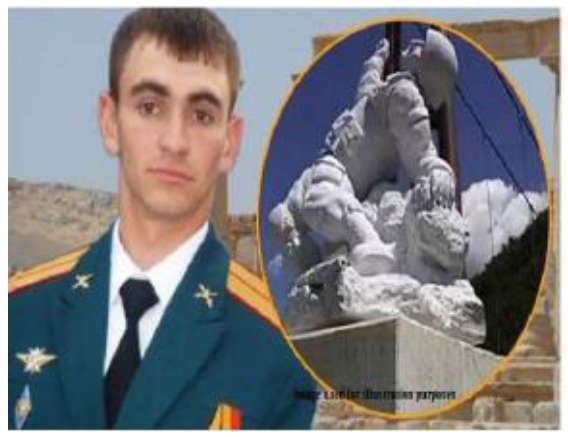

Figure 2b: A Russian victim of Haj-Obama's dogmatic plague in Syria

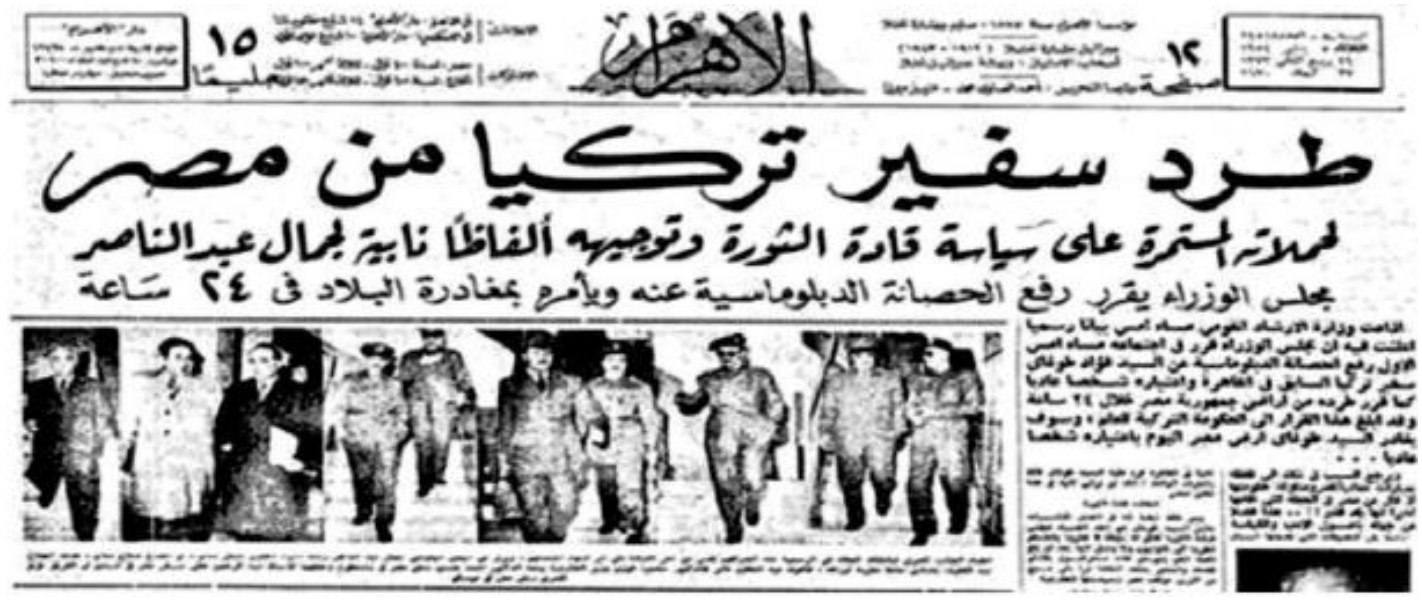

Figure 2C: A reminder to the clique H Clinton-Obama-Biden: 1950s US Disgraceful Erdoganization of Egypt. Al-Ahram 1952 Newspaper Extract.

The Ancient Egyptian-Assyrian cultural feud continued to flare post Dioscorous-I's forceful banishment and death on the island of Gangra and Leo's assumption of the typical Alexandrian notation of Pope. Namely; the Crusades (1096-1271) miserably failed to quench the Ancient Egyptian's definition of The aw and regain lands conquered by the nomads, accordingly, resorted to ecumenism. Prior to Napoleonic conquest of Egypt, the Leibniz's Egypt plan (1671-2) was formulated either as a holy war with identifiable political, economic and religious benefits to persuade Louis 14th to invade Egypt or a distraction strategy to abort wars among European states. According to Ian Almond, Egypt's plan involved a rather cynical use of Christianity as a slightly superficial decoration to an essentially politically motivated invasion of Egypt. That is a holy war would be more palatable to France's allies and enemies. Leibniz believed that the execution of the plan would lead to the flowering of co-operation and brotherhood among Christians in a show of interdenominational koinonia, that is fellowship with other Christians in the participation of shared goals.

In synchrony with Leibniz's Egypt plan, Rome initiated a fervent drive to sway Coptic Alexandria to the Catholic definition of faith that is tainted with the Assyrian-Nestorianiam. Thus, an arabic version of a Latin document entitled "The Essence of the Chalcedonian Orthodox Council Regarding the Origins of the Eutychian Heresy" was penciled in 1694 to the Coptic Pope of Alexandria, document 3. The drive failed as architects of the scheme failed to comprehend in the first place the Church of Alexandria is imperatively a National Egyptian Church with 7000 years roots that is characteristically defined according to Menas Narmer.

One of the major impacts of the 1798-1801 Napoleonic invasion of Egypt was the implementation of the Leibniz plan. Napoleonic edict his solders reflects exceptional understanding of the Islamic theology which is a pointer to the Leibniz plan. In collaboration with the Ottomans in 1829, Rome was allowed to build their own churches in Egypt. In 1895, Leo $13^{\text {th }}$ of Rome appointed bishop Cyril Makarios as Cyril-II, the oriental-Catholic patriarch to Alexandria. Thus, the Oriental Catholics in Egypt will always be regarded by the National Copts - specially the Alexandrians - as a remnant reminder to the venomous chain of events which were schemed to quench the uniqueness of the Ancient Egyptian civilization and culture as early as the Asian Hyksos settlement in Avaris, Anthony and Cleopatra, Emperors Constantine and Marcian, the Mongols and the 2013-Mursi.

Fabric-wise, the yield was a similar set of thoughts with sharp edges proportional to environmental and intellectual aridness of the desert. Among many, the major victim of Retro-Akhenatenism was the fall of Byzantium 1453. However, was blemished with the evolution of sporadic pouches of aggression saturated with equal characteristics of mental aberrations, material dearth and psychological melancholies of the past elders. Recently, the 
dogmatic tribunal sentenced "stabbing" of the Canadian novelist, RW Roberts author of "Palace of Fears" [14], on the account of his irreverence of Islam. Most recently, in Paris, a French professor of history was decapitated by an 18y old Chechen immigre-militant on the account of teaching liberty and freedom of expression. That is absolutely inconceivable and pathetic. This Chechen $18 \mathrm{y}$ boy was in essence deprived of a happy childhood, too young to experience love and parenthood. What are the specifics of the hate-diet he was milked as a child to commit this ghastly crime at $18 \mathrm{y}$ old? This is for the professional sociologists and psychiatrists to digest and analyse to provide, if possible at all peaceful means to quench it prior to turning "Out of Control Dilemma". The US supported the dismantling of former Yugoslavia according to religious boundaries (Kosovans) in local war fields which were soaked with the blood of the innocents. Accordingly, Putin accusation of the US of having had direct dialogue with Chechen separatists, whom were likened to Osama Bin Laden, is credible, indeed. Indecently after a hostagetaking at a school in the North Ossetian town of Beslan that took place on Sept. 1-3, 2004, the notorious Chechen Wahhabi Shamil Basayev had claimed responsibility.

Currently, worldwide these variants of dogmatic militants embracing various pouches of aggression tailored according to the characteristics of their religious domain have incubated many crazy-glued petri-dishes in North America, Europe (specifically the New Mecca-Paris' Eiffel tower and the turbaned London), Russia and China. Presumably, to those who have ears to listen may entertain the inevitability of the WTC $9 / 11$ as a litmus indicator to the eclipse of the civility of the de novo re-Akhenatenized Western World according to Martin Luther.

A. Neurotic and un-proportional dealing with an imaginary threat posed by The peaceful Carpenter, Yeshua

At the time, the Israelites psyche was in captivity to the ruthless might of the Roman Empire. In effect, the religious elite/ the Sanhedrin failed utterly to foresee the fragility of their domain 3 days post the procedural dynamics of the law and order of the Roman Empire. To start with, they carried their intimate theological differences to a Roman court to settle it. Incidentally, the magistrate Pontius Pilate entertained a different set of believes! Worse, as lived in total isolation they did not expect the Roman justice would allow an accused Israeli National with a modest profession: carpentry, the latitude to defend Himself? In modern terms; shall we say; Pilate gave The Accused the benefit of doubts until He is proven guilty? Contrary to the aspiration of the emotionally entangled religious elite, the immediate outcome of the proceedings were 3 days of agitations and turmoil which were the overture to a Greekeducated fellow of their own ranks to baptize the long march to the $\boldsymbol{R} \boldsymbol{e}$-Akhenatenization of Rome. That is, the seed of a $\boldsymbol{R} \boldsymbol{e}$ Akhenatenism was sowed and polymerized free-radically to yield a solid texture of a rival setting. Concomitantly, the daily events of the period were blemished with violence, viz., one of their younger members, Stephanous, was found blasphemous on the account of harboring the doctrinal core of the Crucified Carpenter. Absolutely, the aggressive events crippled the heavily burdened populace. As were mentally tormented with the dealings post the Crucifixion, they opted for street justice and eventually showered Stephanous with stones to death. Thus, became the first martyr of the newly established Re-Akhenatenism. Furthermore, law and order of the Romans Empire saved the Greek-educated Rabbi Paul from entertaining the fate of the decent $30 \mathrm{y}$ old Carpenter. Paul was a Roman citizen which obliged standing trial in a Roman court. The irony is while waiting for trial at a Roman court, Paul managed to convert the working class and the dispossessed to the new theme of thoughts. This was an expected culmination to Cleopatra's tutoring the Roman court, e.g., Marcus Antonius et al., on the Ancient Egyptian Deities. In modern understanding; Paul organized the working-class in a coherent body where they can find solace to the degradation of their humanity in sporting arenas; against each other or wild beasts to appease the tyranny of the few fat-cats. Shall we say, the second communist body, the Church as an institution, which was a better establishment vis-à-vis the first hut founded by the emotive fisherman in Jerusalem, Peter. At this very point of time Nero put Rome in flames and Paul was executed as his threat to the political stability and religious harmony of Rome became evident. At this particular junction, we may entertain the positive contribution Pharaoh Akhenaten bestowed the modern world, briefly the advanced thoughts of sharing living in a community village by the RN, todays communism. Said formulation defeated Isis/ Da'aesh as Ra-mosa defeated their Syrian ancestors in Kadesh. In brief, basics of Akhenatenism which were entertained by many progressive-intellectuals invoked the red scare 1947-1960 which masterminded the US-assasination of its intellectual figures, lynching of Korea, Vietnam, Cuba and Chile and engineering Sadat, Suharto and African destabilizing coups and the assassination of Indira Gandhi. We may entertain the query; how different the world today would be should Akhenaten's clergy remained in Egypt and the child Pharaoh Tutankhaten was not assassinated?

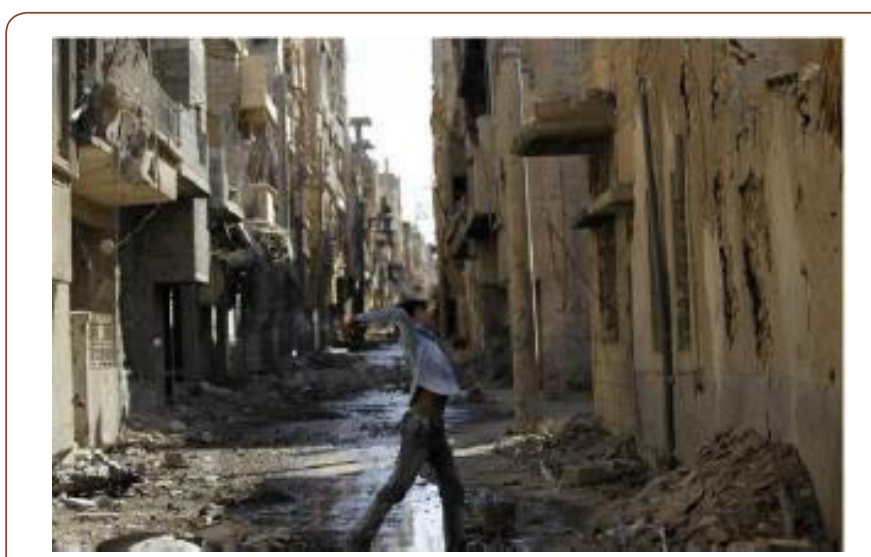

Figure 3a: Dogmatic KKK's looting of war-tattered Syria 


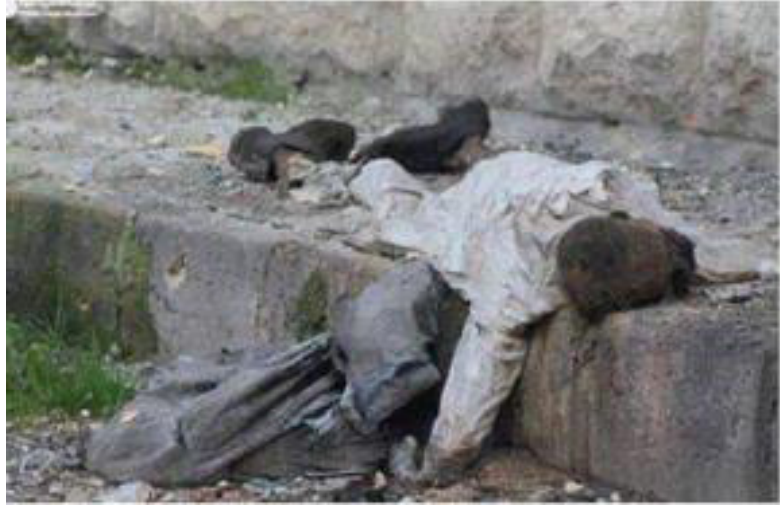

Figure 3b: A decomposing remains of a Syrian child of the very many victims who fell to Haj-Obama's dogmatic Erdoganization.

At this particular point we may safely conclude: the Decent Carpenter was cognizant of the magnitude of the heavy burden the common Israelites were carrying while the few rich, e.g., Herod Antipas, tax collectors and the likes, are harvesting the leisurely life and comfort of their association to the Romans. Mindful of the expected retaliatory risks associated with an open revolt against the Romans, viz., the defeat of Spartacus and the slaughter of children and women which marked the third Servile war, He opted for a pacifying strategy to absorb the anguish of His people. According to available Manuscripts, He was always in the company of the working class. That is, the poor, the sick, the destitute who for survival opted for adultery, despised individuals who were characterized as sinners, etc., to give them solace to vent their energy to the peaceful Akhenatenized heavens. Thus, He monetarily managed to steer the rage of the destitute into peaceful sublimations vis-àvis unfavorable societal turmoil. Shall we call Yeshua, the spiritual Spartacus? His drive unsettled the religious elite especially, at the gates of Jerusalem, He was hailed as the Savior. However, politically the Decent Carpenter was no match to the well-organized religious court as shrewdly, they managed to portray Him to the Israelites mass as trying to obliterate the traditions of the elders and to Pontius Pilate as a perilous dreamer who crowned Himself "The King of the Israelites" in lieu of Roman Emperor. Thus, distanced themselves from the societal misery of the common Israelites and successfully channeled the rage and the dissatisfaction of the destitute into hysteric shouting and sadistic cheering in the arena of His physical abuse by the Romans prior to His crucifixion.

Above would highlight the following two vital parameters which should be considered by the current Egyptian religious hierarchies that are solely consumed with the "sinful" versus the "blessed" acts of a believer to the Almighty and the extrapolating ridicule of: does applying a necessary nasal droplets medication break the fast and equally preposterous: does eating a tiny piece of cheese or adding milk to coffee would contradict fasting?

- $\quad$ at the time, although dominated by the Romans, the religious elite typically mastered the ultimate authority and the Pinocchionization of the masses. On the account of preserving the faith of the elders, the misery of the mases burdened with the load of poverty and lack of education were managed to disfavor the same very Person calling for their salvation; Yeshua. The Sanhedrim palpated and quenched the commoners' dark corners. Thus, availed the joy of the free gathering to witness the spilling blood of the weak in the gladiators' arenas of violence, and

- $\quad$ it is easier to excel in an environment void of stern religious dictates, viz., the ease of seeding the fall of the tyranny of the Roman Empire to Paul's passive tackling of the sentiments of the dispossessed vis-à-vis the failure of the Decent Carpenter in a Jerusalem - suffocated by an unyielding ring of a reactionary clerical elite.

Same street justice of a 3000y old Ancient Egyptian village which claimed the life of Pharaoh Tutankhamun reverberated in 1947-1960 US Congressional edicts. These edicts were the assassination of three gentlemen and scholars, JF Kennedy, ML King and RF Kennedy and the overture to the current intellectual malaise of the US political establishment. Worse, was the pioneering call of a notorious Austrian monk for the supremacy of the Arians on whose account the shame of 1939-45 genocide, i.e., the massacre of mutilated 6 million innocents, is irreversibly glued to humanity, viz., Hitler Stole my Ideas, by Adolf Josef Lanz (1874-1945 [15]), and

B. They never learned from the blunder committed by their grandfathers 600 years earlier. In zeal to dilute it, they tailored for their distant cousin, a nomadic dressed theme of RetroAkhenatenization. At this particular time, hypothetically if Arabia was strictly ruled by the law and order of the Roman Empire, it is most probable; the Retro-Akhenatenization coup would have either failed at birth or molded with different arrangements. The probable arrangements could have labored a hypothetical nomadic Messiah and a pardoned Barabbas. Literally, Retro-Akhenatenization was labored in a hostile environment among aggressive tribes. Tribal belligerency forced the early believers to seek refuge in Yemen and Ethiopia until better circumstance allowed their return. After this sabbatical, the believers returned to their habitant fully-fledged in strength to combat and subjugate nearby tribes at the time and currently many scattered and isolated pockets In Europe, North America, Russia and China. As litmus to maximal aggression, the power struggle of Retro-Akhenatenization, a well vortexed theme with its environment, at its incipience was: three of the first four Kalifates were assassinated by opponent tribes. The major outcome was the elimination of the Israelites of Arabia altogether, Banu Al Horayth, Banu Nadir, Banu Qaynuqa, Banu Qurayza, etc. In effect, history of human ethics will always be pregnant with the shame of the very many Holocausts, the 600, 1915, 1939-1945 and 2015. With certainty, the general decline of the refined ethics and spirit of Golda Meir's motherly magic touch was evident: "We do not rejoice in victories. We rejoice when a new kind of cotton in grown and when strawberries bloom in Israel [16]" and "We can forgive the Arabs for killing our children. We cannot forgive them for forcing us to kill their children. We will only have peace with the Arabs when they love their children more than they hate us [17]". 


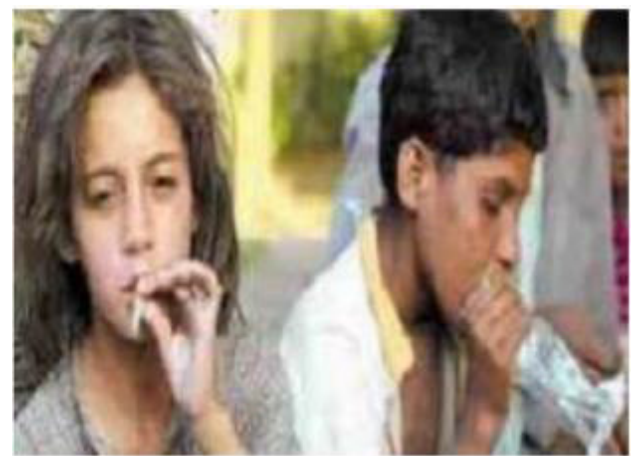

Figure 4a: Societal accumulates of Mursi.

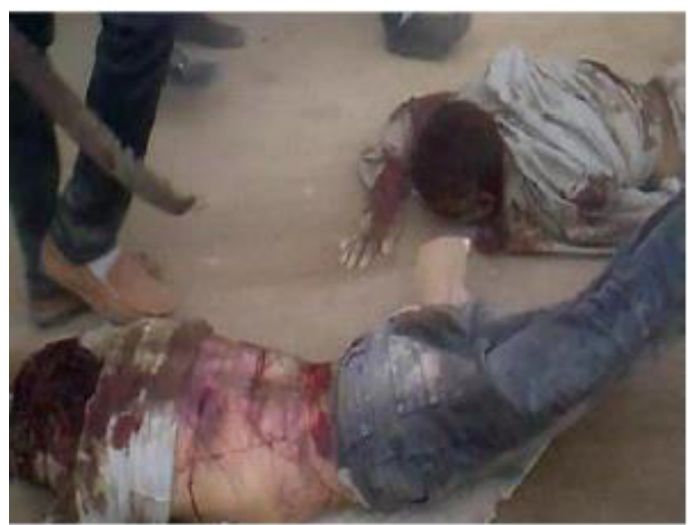

Figure 4b: 2012 Lynching of a Shiite in Egypt

To our contention; it could be concluded, while appreciating the different political circumstance at the time, events (A) and (B) above best describe a common disastrous consequence to members of an emotionally fatigued minority in cohabitation with a hostile majority. Concomitantly both are bound to different sets of religious wave lengths laid down by environmentally constructed different variances of the same and one Omnipotent! In conclusion; the main features of the world and working dynamics of peace would have been different if above plunders (A) and (B) were not committed, e.g., owners of oil fields would have carried different inclinations. Thus, (i) would not allow the sprout of radical dogmatism and (ii) placed both TE Lawrence, Gertrude ML Bell and others on the unemployment list of the British Empire.

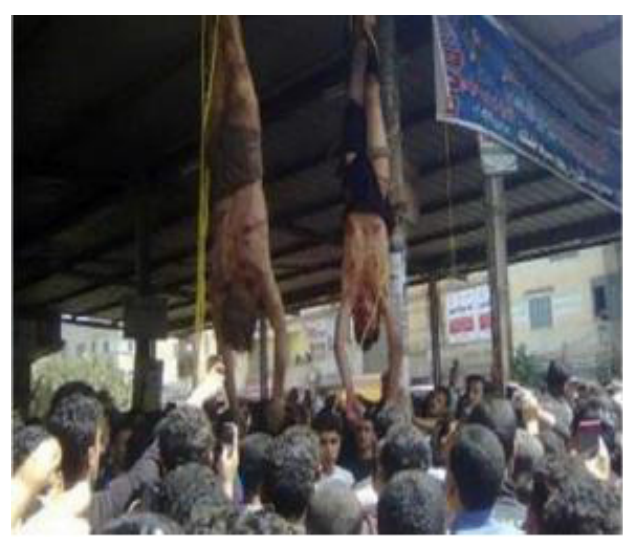

Figure 4C: Egyptian Victims of Mursi's thugs.

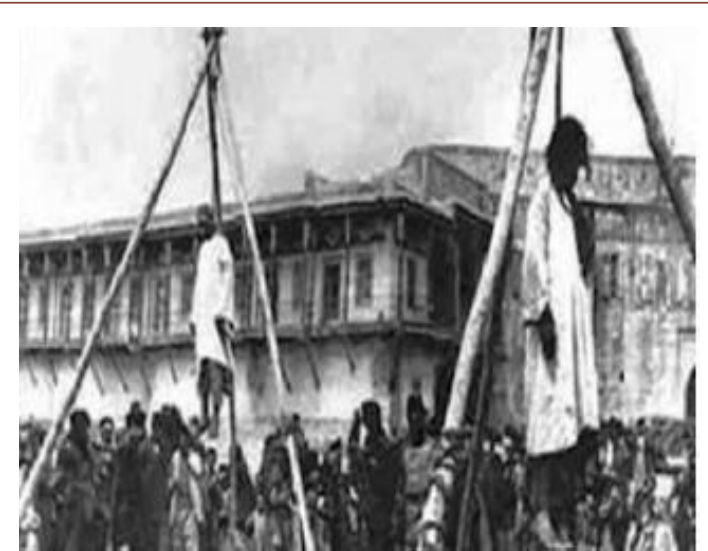

Figure 4d: Armenian victims of Turkish Holocaust.

Dogma-induced mental aberrations and environmental devastations

Here below are two examples of recent events:

- In the city center of Kabul, Afghanistan the police arrested an Afghani suicide bomber while attempting to blow up himself inside a crowded mall to maximize injuries among women and children. He declined sacrificing himself and was arrested. While thoroughly searching the pious terrorist, to the surprise of the police officers, they found his penis enclosed within a thick cylinder made of titanium-resistant to explosion. When officers inquired about the wisdom behind configuring his penis in a titanium tube? the absurd response of the mentally comatose jihadi was; to have it intact of possible injuries. This is to take maximal advantage of the promised mating with the ever-lasting boys and the seventy-two nymphs in heaven in case of death while waging jihad (Data, Figure 1a)!

The pertinent question here is: how a shallow educated Afghani knew of the titanium-alloy characteristics of resistance to explosion? And availability of titanium tubes resistant to explosions in a land ravished with $20 \mathrm{y}$ of war? This is indicative of the facile tailoring of the ignorant bedouins' psyche to wholly embrace radical dogmatism. It may be time consuming, however elevating awareness of these particular individuals to the utopian parallel of respect, sanctifying of human's life and learning from opposing second thoughts and ideals is absolutely much cheaper than military interventions and ceaseless rocket's bombardment. Education will chiefly (i) save on experimentally new weaponriesinducing environmental necrosis at distant locations, (ii) minimize on loss of lives and casualties on all sides, (iii) reduce societal burden of accommodating desert-wars returnees plagued with physical injuries and infectious psychological aberrations, genetically modified bacterial and viral organism and (iv) eliminates racial profiling and dogmatic characterization. The posture of the Pontiff leaning, kissing the boots of the feuding war lords and imploring them to cease killing of innocent civilians should light the tunnel of Post 1963-68's political anomaly. 
- In the year $2 K+12$ a Ph.D. learned mufti, Dr. Abdul Majeed El Zandani claimed (Data, Figure 1b)! the beard beard of pious Sunnis is a protective filter against coronavirus. His bizarre rational is the said virus is heavier than air; the beard would then protect the pious Sunni against invasion of the coronavirus to the respiratory system! and

Although toilets with running water are available, the nomads are bound to wiping their rear with sand or stone after defecation, etc. This is a rich recipe to effectuate plagues of lethal viral and bacterial diseases - Black Death - in their arid environment. These diseases are freely exported to adjacent local cities and Europe on the account of cheap air travels. A recent UN health agency report on ten polio cases, among toddlers is a confirmation to the health volatility of the Middle East <news.yahoo.com/syrian-foreignjihadis-said-responsible-polio- 200905732.html>. Poverty-induced (i) local environmental necrosis in Egypt and (ii) exportation of Western refuse to Indonesia would hasten the free transmittance, infestation of tropical disease and psychological aberrations to Europe [18] and other parts of the world. In this regard, considering the advanced knowledge of polymeric and micro-plastic-induced intoxication, diseases and environmental necrosis, the option of the facile discharge of plastic refuse to the underdeveloped nations - in lieu of dedicated recycling, cleaning oceans of the enormous debris of floating plastics, and micro-plastics - is a premeditated crime against these abandoned communities. We dare say, this a large scale human slaying with consent, that is not less than tthe Nazi Gas Chambers. Thus, the chemists' moral obligation is to disregard the I-in-C's bombast marketing pertaining to the genesis of environmental erosion and covid-19 exponential infestation according to its weight of salt. That is to boldly decide on worldwide mechanisms of strict and unyielding control/ ban on daily singleuse of plastic products as of shopping centers' plastic bags, fast food restaurants' coffee cups, soft drinks' containers, etc. This particular ethical failure of Western politicians is synonymous with the Mongols' crime at siege of Caffa (spreading bubonic plagues 1347) and the early settlers (proving Indians with smallpox blankets 1763 Pontiac's Rebellion). Viz., Elisabeth Rosenthal, Smuggling Europe's Waste to Poorer Countries, The New York Times, Sept. 26, 2009.

\section{On the genesis of dogmatic-induced environmental erosion}

Most recently, on the account of the expiry of the dogmatic Führer Mursi, the US and Western political establishment televised their typical provoking claims. These bombasts are calculated blunders to evoke political instability in Egypt. These blunders are ultimately leaked to incite Egyptians' Jihadists to sharpen their machetes for a protracted internal strife that is beneficial to Western fat cats. Gleefully, Westerners are generously watering the seeds of lethal dogmatism which were sowed by an earlier generation of British scholars. Indeed, expiry of Mursi was a political feat to the political fools who are never cognizant of the long-range damage done by Mr. Hempher, GM Bell [19] and TE Lawrence [20] to worldwide tranquility. Positively, the toil of these scholars contributed to fall of the evil-empire, Turkey. Prior to Hempher, Bell and Lawrence, the genius Egyptians launched the first drive to mitigate the causticity of the Turco-Mongols threat. That is the Ottoman-Egyptian War (1831-33 [21]). The Egyptian forces occupied the city of Konya in central Anatolia, within striking distance of the capital, Constantinople. The Western gene of self-destruction motivated an Anglo-French measure against the Egyptians, Convention of Kütahya (May 1833 [22]). Same Western self-destructive genes frustrated the inevitability of the liberation of Constantinople, the Greek-Turkish war (1919-22 [23]). Endless do loop of Western foolishness! For example, Lord Mountbatten's unequivocal support to Ali Jinnah to fragment the Indian subcontinent, the creation and US-assisted nuclearization of the Sunni-theocratic Pakistan, lending support to Adnan Menderes against Nasser (1955-1957), handover of Cyprus to Turkey (1974), the (2001) creation of a bestial culture in Turkey subsisting on the recessed psychic of the illiterates, e.g., the AKP party in Turkey, etc.

\section{In this context; Let us consider some phonetical litmus:}

*When Byzantium was subjugated, Mongols inserted their warrior genes into DNA strands of the Greek populace. Previously, these warrior's genes manifested the 656 AD surge of violent characteristics of the corrupt third Kalifate, Uthman ben Affan which were the prelude to the foundation of the Shiite sect and the assassins. Early Mongols used to feed their babies on Airag Айраг, а 2\% alcoholic mare's milk, for better well-built warriors and savageries in duels and battles. Currently, Airag (phonetically synonymous with Arkhi) is Turkey's favorite drink. Arkhi is available in Turkic stores and previous satellites, Egypt, Syria, Lebanon, Iraq, etc. According to the works of the Iranian historian Rashid al-Din (1247-1318), the Mongols killed more than 700,000 people in Merv and more than a million in Nishapur. To confirm environmental devastation, the Mongols left the bodies of $\sim 40$ million slaughtered individuals to putrefaction in jihad's fields of exterminations.

The disgrace is the mongrel psychology of human's natural disposition to commit scandalous crimes against humanity has matured according to ripeness of conscious. The mass eradication of the native Indians took place earlier to the 1939-45 of the Jews. To decimate the Indian population of North America, the early settlers purposely provided the Indian tribes with smallpox- contaminated blankets [24]. Similarly, in preparation to purge the Iraqis, a Hollywood's fabricated lamentation, challenged the UN members with a vial of anthrax rather than smallpox-contaminated blankets a as a finger print to Sadam's weapons of mass destruction!

Contrary to the rancid theme of many speakers/ guest speakers at the Oxford Union, with great certainty it is safe to assume should Sophia Palaiologina and Ivan III (1440-1505) failed to lay the foundations of the Russian state and renovate the Moscow Kremlin post defeating the Mongols/ the Turkicized khanate of the Golden Horde, Europe and the USA would have been the same as 
the Middle Eastern scattered countries and remained the forestry of the Mississippi respectively with their flags carrying the same notations à la the nomads. Similarly, for the second time, Russia (1940-1945) managed to defeat Hitler's-Kosovan-Wahhabis alliance, thus saved decorating the European and USA flags with Nazi Swastikas and the Syrians of entertaining the fate of the Armenians (Data, Figure 2a). For the third time, Russia debilitated the tyranny of the USA- supported Middle Eastern dogmatic militants. Optimally interrupted the dislocation of Middle Eastern refugees, thus momentarily halted the spread of a wide spectrum of second-generation diseases, environmental intoxication and caustic-deranged dogmatism. In recognition to his heroism while the Russian were engaged in fierce neutralization of the USsupported ISIS' militia, the Italian Association of Parachutists dedicated its $161^{\circ}$ course to a fallen Russian officer in Syria (2016); Alexander Prokhorenko (Data, Figure 2b).

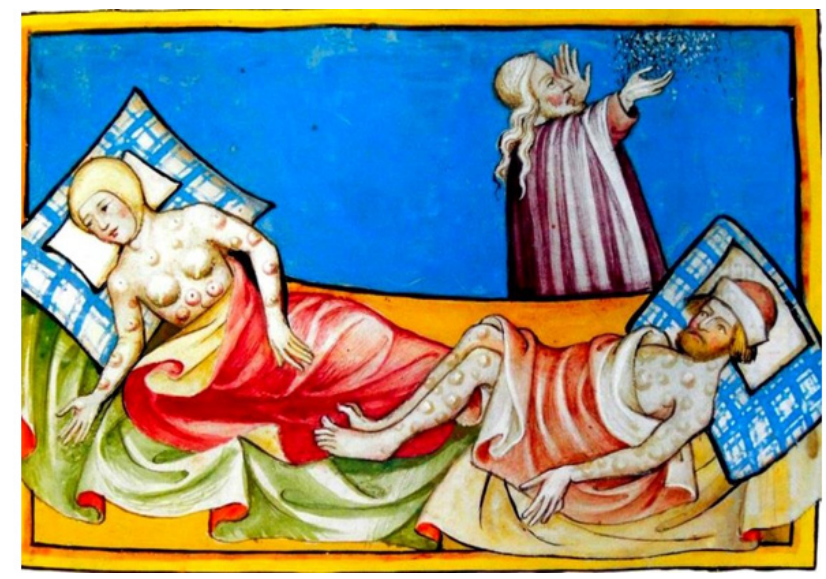

*In Arabic, the name Racep Tayyib Erdoganis اردوخان طيب رجب or اردوغان طيب رجب that is phonetically synonymous with which upon translation to English would yield the Racep Tayyib Arabkhana. The implication is; his elders were attending coffee and other characteristic necessities of the time to clienteles of an Arab coffee shop. The fat cats in control of the Western political establishments ought to wise up to reconsider their supporting modalities to the Middle Eastern Wahhabis before the world-wide environmental necrosis and dogmatic mental aberration (decapitation of the French teacher) turns into last stage malignancy. Thus, a serious life-threatening force to the mere existence of humanity. Consider the event described in 1954 Egyptian newspaper below (al-Ahram Newspaper Extract, Data Figure 2c) to realize the do-loop blunders of the US Sisyphus as of Eisenhower, Carter, Reagan, Clinton, Bush the spoke, Bush the war president, H Obama, the Maître d'hôtel, it is an endless SASGF.

Putin, with ultimate precision understood, accordingly quantitated and shrewdly manipulated the Uthmanic tendencies of Erdogan. Erdogan, the political imbecile, was allowed to bask in a transient glory of a lunatic revitalization of the Kalifates of Uthman by syphoning the nomadic militants from the Russian zone of interest in Syria to be the target of the European-Egyptian coalition in the Libyan wasteland. Shall we say the Vietnamization of Libya which would ultimately excise the Turkish threat to civilization? That was a superbly intelligent Putin-free vacuum cleaning by proxy. Typically, Erdogan crowned his gullibility by converting the Agi $\alpha$ Sofi $\alpha$ to a Mosque as much as Sadat was reveling in the sermons of Sheikh Sha'arawi to the constituency of the religious comatose. Most likely, Erdogan did not gauge the consequences of his endeavor as Sadat's ill- gamble on Sheikh Sha'arawi did optimize his demise; the Greek drama of October 6, 1981.

The qualification of the character picked by the US establishment to manage the revival of the Turkic empire is almost a mirror image to the British hand-picked Hassan El Banna to revive the nomadic Kalifates! Thus, with ample certainty it is analytically conceivable to settle to the conclusion: as always; it has been very few fat-cats who reaped the most of the arranged dogmatic conflicts while the disadvantaged nationals harvested the long range repercussion of the British and the US lunatic revitalization of the nomadic and Uthmanic Kalifates respectively. [visualize: On December 16, 2011, leaked H Clinton's emails revealed a secret sessions held by M Badie and his advisers, including Mursi along with a number of US officials to inform them of the group's future plans in Egypt. Badie and close advisors were developing plans to run the Egyptian state after adopting a new constitution for the country and electing a new government in 2012, with the new Egypt being an Islamic state along the lines of the Turkish model.] The glaring examples are the Holocaust of the Armenians (1915-17), the execution of M Daniel and KM Saeed in Egypt proper and the Egyptians in Libya, slaughter of a Shiite imam by Sunni Ku Klux Klan in Giza and environmental devastation in Syria. In brief, atrocities said above are indicative of these dogmatic warrior are carrying (Nazi) genes. Let the blood of M Daniel, KM Saeed, Egyptians slaughtered in Libya, Kerdasa and Rabaa Al Adaweyah be of the head of Obama and H Clinton and their children (Mathew 27:25).

Nonetheless, for the sake of the total monopoly of the everpolluting crude oil fields, the ravenousness of the MIC-food industry and pharmaceutical conglomerates, bayoneted the Arab Spring in the Middle East. Thus, a clownish Wahhabi-Frankenstein was 
created. As it turned out, the election of Mursi to lead the wolves' pact was not necessarily a well calculated option. Although Obama's intent was to whirlwind Middle Eastern countries in Mursi's orbit to resurrect the nomadic Kalifates, the Egyptian ladies pre-empted his aspiration. Thus, momentarily worldwide peace was safe guarded of impending Wahhabis terror and violence and ensuing ecological disasters. Prior to his expiry, Führer Mursi managed for many refugees with all shades of de novo genotypes of diseases and mental aberrations to settle in the lands of his Western masters. As we see it; the conclusion of Obama's Arab Spring remained an aching disastrous event that is shattering the integrity of the USA.

Yet, the mentally incapacitating ridicule of the neo-J Goebbels' Western media was pertaining to the death of the so-called democratically elected dogmatic Führer, Mursi! Most recently, said Goebbels' media has claimed the Wahhabi-Führer's death was a "fullfledged murder" which requires an international inquiry. This is a well-organized US profitable conspiracy suggestion to destabilize secular Egypt. To start with (i) the dogmatic Führer's election was Clinton-doctored in his favor, and (ii) it is more amenable to assume the abrupt collapse of the disease consumed $\sim 70 \mathrm{y}$ old Mursi (as was of tender age in active contract with HCV- $4 \mathrm{~b}$ and Schistosoma on the account of his filthy milieu) was the expected outcome to his (i) previous brain surgery to remove a tumor and (ii) kidney failure and chronic diabetes. As for the trumpeted Western media circulation "Mursi had been mistreated and tortured in jail" has no justification whatsoever. It would have been logical to consider the well-publicized human abuse in "2004 Abu-Ghraib [18]", “Operation Ranch Hand 1961-1971 [27]", etc., prior to welltailored rumoring the martyrdom of Mursi. It negates the simple back of an envelope calculation; a consumed human body of $70 \mathrm{y}$ old Mursi which was stricken with HCV4-b, diabetes, kidney failure and used to dreadfully consume atrocious quantities of specially ordered food would withstand 7y of torture in jail. Narcissistically, the clownish Khedewvi-Erdogan: while lamenting the departure of Führer Mursi, he opted not only for a total denial of the 1.5 million Armenians holocaust but also, in total silence of the Western world, whole heartedly engaged in Endlösung der Armenians in NagomoKarabakh.

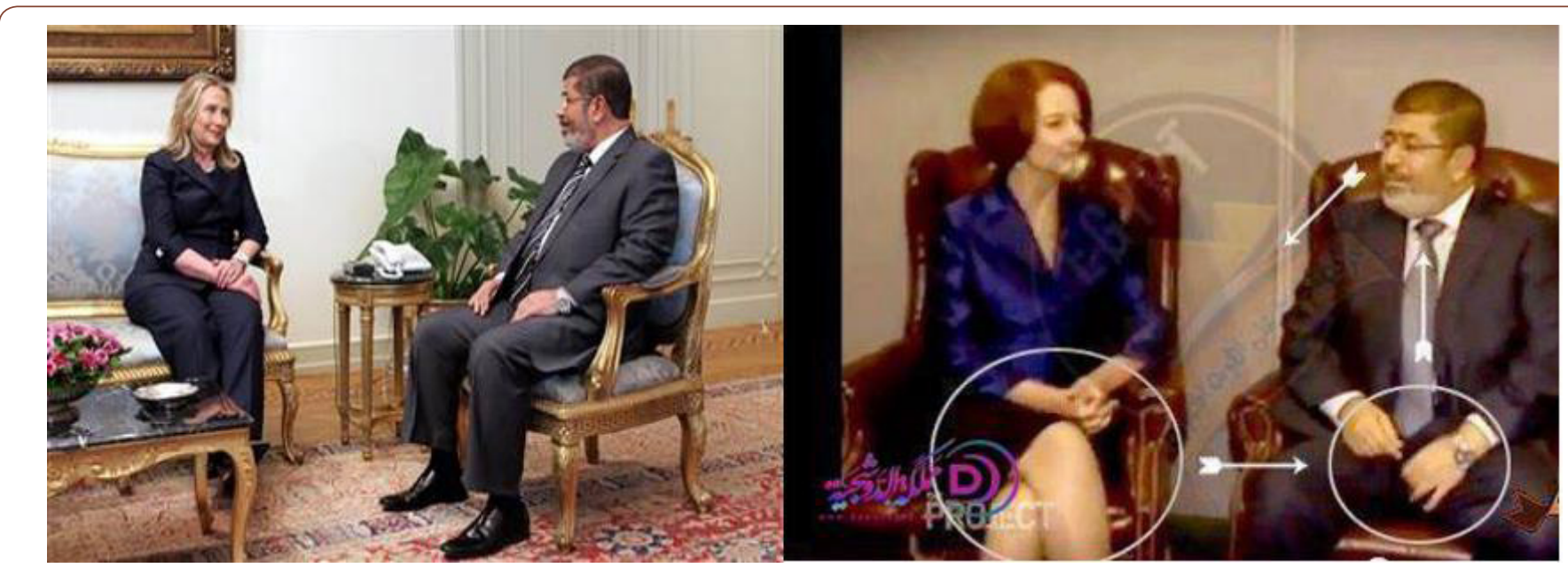

H Clinton's awareness of Mursi's dogmatism made her well covered and on guards while meeting him.

\section{Discussion}

\section{The cultural clash and the discontent of civilization}

The 641 nomads and 1437 Mongols have primarily instigated the clash of civilization. While shrouding in an odd blend of a selfagonizing inferiority and better than thou attitude, they burned the library of Alexandria as arrogantly claimed we do not need these books as we have all in our manuscript. Thus, the cultural records of more than $8000 \mathrm{y}$ of civilization were smothered in favor of the metaphysics. This catastrophe did waste and deprive the Western world of bout $8000 \mathrm{y}$ of human's knowledge, wisdom and mental toil. The world of science, medicine, arts, social values and spiritualism would have been in exponentially elevated standards should Westerners have initiated their scientific pursuit at the gates of the library of Alexandria. For example, at that distant time, the Ancient Egyptians knew the details of human anatomy when Europeans were punished by death if alleged of examining a cadaver; the dark ages. At that distant time, the dogmatic verbal greeting of the burning of the Library of Alexandria were the very same ones which expressed joy to the recent destruction of the Buddha monument / Bamiyan valley, the 9/11, the dismemberment of Yugoslavia, Iraq and Afghanistan wars, failed attempt on Syrian sovereignty, the 2015 beheading of 21 Egyptians in Sirte Libya, etc. Below depictions are indicative of an acute Western mental fatigue. Alarmingly, according to suckling at Indonesian Madrasa, it is no coincidence Haj-Obama has deliberately rather than naïvely appointed many Wahhabis to top posts in Washington DC, i.e., Homeland Security, the Army and Intelligence. In effect these, appointments are the Wahhabi catalyst to free radically multiply zealotry aberrations within the USA proper. Why not? The suitably rich incubation media was freely provided by oil dollars. This is to guard their interest as of Hitler to present day figures who claim ethical superiority according to the rancid definitions of human rights' and democracy of the fatcats? Ultimately, they multiplied to occupy the White House, came very close to the British Monarchy, bankrupted the US treasury in desert wars, claimed the lives of thousands of US youth and inflected chronic aberrations on the psychological state of mind 
of returning troops. It is rather expensive and time demanding to untie the societal inflected damage to close family members. The desert war-computer returnees are plagued with perplexed ethics and personalities which culminate to self-injuries or peers abuse, suicide, and heinous domestic crimes. The young generalNapoleon Bonaparte pioneered the palpitation of the urgent details of the Middle Eastern historical past while preparing his campaign in Egypt, viz., 1671, Leibniz's Egypt plan. He correctly identified the putrefying Turkish Kalifates as hegemony of a theocratic dictatorship to a populace of a culturally distinct and superior milieu, however riddled Egypt. In this context, it is plausible to conclude the intelligent culture of Bonaparte, viz., his first proclamation to the people of Egypt while his forces were in route to Alexandria, is urgently required to combat environmental ruin. By comparison, the inexperienced US-politicians engineered the 1952-Wahhabi coup in Egypt which turned the Middle East into an environmental refuse and the prime exporter of second generation bacterial and viral insults and convoluted dogmatic militancy to Europe. According to the same yardstick, a recent cultural-political divide pertaining to the Iranian enrichment dilemma, Macron's political professionalism versus the Maître d'hôtel has irrevocably manifested itself.

\section{The clash of advancement and know-how}

The most valued heritage, the sacredness of human value was lost in a maze of GPS and computer games. In modern fields of death, humans became dots to trace on the computers' screen to delete? It is the psychology of modern cowboys who became computer operators: rather than attaining the satisfaction of itching names and numbers of laid victim on their belts, the computer operators would momentarily dart into the climax and euphoria of deletion of many lives of helpless opposing individuals that were minimized to computer's dots. This euphoria would camouflage differently into his /her subconscious. It is the routine at this worthless sandy spot 1000s of miles away from home, when cowboy combatants get together in an isolated underground well-guarded kitchen, over beer and smoking cigars, they proudly would count and compare number of deleted human spots! Scrutinising this attitude, it is a sublimation of an innate fear of possible imminent attack which could claim their lives. Nevertheless, this euphoria of deleting opponents will turn to haunt him. This embedded violence would transmit the wrong signals to younger generation and would temporarily create superiority complex and status' miniaturization of others until, assuming news media's reporting has some integrity, a dramatic event as WTC tackles his/ her conscience. Claiming efficiency, saving on time and providing better service; advances in computers' technology has hatched the characterization of the lay humans' intent and emotion, as well fast orders in restaurants and shopping centers to order meals and groceries respectively. Thus, faster money cycling in trade is expected which would work in favor of the few fat-cats. We organic chemists see it differently: on the long run an array of psychological drifts is anticipated to plague the laypersons as human contacts are restricted to computers' key boards, i.e., self-imposed social evisceration of human proximity, synthetic withdrawal and selective autism. That is almost a state legalized violence in the name of patriotic monopoly of energy and agricultural resources.

A review of recent topics published in the periodical Popular Science, 2019 [31] pertaining to The New Artificial Intelligence; one may realize the peak of the chronically disadvantaged nomads who are fiercely debating advantages of drinking camel's urine and/ or prayers versus the scientific Western advancements. While, topics of Popular Science, 2019 debated the titles: How Can We Teach Morals to Robots By Telling Them Stories?, Algorithm Binge-Watches TV to Predict Human Behavior; The Curiosity Rover and Other Spacecraft Are Beginning to Think for Themselves, How to Create Super intelligent Machines That Won't Kill Us, etc., at noon-time the mutawa (religious police) are discharging to enjoining the good and forbidding the wrong, the least is to oblige circulating laymen to attend prayers. In conclusion, they were willingly taken hostage to the saying of their elders. While interwoven into the sayings of their elders, they are unaware of the expected sophistication in computers' management of a human computer in response to the widespread male impotence. That is, the:

\section{The reproductive computer}

In view of the exponential innovations in computer rheostat of biological functions, it is very plausible to suggest a protocol of controlled in-vitro insemination; a sperm of choice - elected from a pool of available frozen sperm aliquots - of specifically selected ova contained in an isolated perfused uterus. Periodic DNA assessment of amniotic fluid will be carried out to monitor the viability of both the motor functions and mental faculties of the embryo until delivery. Should DNA analyses indicate embryonic deformation(s) an expedient medical repair, surgical or otherwise, or in-vitro abortion could be carried out? Truly, it is a scientific counter to males' infertility and females' diseased uterus; nonetheless, it is rather an invasive procedure to the saneness of human emotions. However, we have to wake up to the reality; the past decades of ladies and gentlemen, viz., JF Kennedy, P Trudeau, L LB Pearson, R Lévesque, Indira Gandhi, Golda Meir, B Bhutto, etc., are kaput all together except for very few individuals are remaining; el-Sissi, Tzipi Livni, V Putin, X Jinping and E Macron, fat-cats will suffocate human faculties and impede reaching the heights of intellectualism.

According to shared values of a hereditary disdain to sanctity of human uniqueness, passionately mufti Amin Al Husseini did recruit the Kosovans/ Albanians and the likes to the service of the Nazi apparatus. Together with Nazi forces, these recruits went into a common Jihad against the Russians. According to Hitler's yardstick, Eisenhower closed ranks with the Egyptian Brotherhood in support of the 1952-coup Wahhabi officers and Khedewvi Adnan Menderes, The US-Wahhabis pact destabilized the Middle East, sparked three Egyptian-Israeli wars, devastated Iraq, Syria, Lebanon and Libya 
into internal strife which claimed the lives of millions, breakup of families' unit, environmental necrosis, outbursts of lethal mental cirrhosis which brought organic and spiritual misery of refugees and death into world's major cities, the Iranian nuclear ambition, etc. The same dogmatic schizophrenia together with all the dark vacuoles of his psyche, Sadat the Nazi-predator happily reciprocated to Carter's mongoloid Camp David's peace accord. Enthusiastically, à la Mufti Al Husseini's immaculate model, he dispatched Egyptian Jihadists to the support of US/ Afghani pact against the Russians.

The mentally unripe US-political establishment failed to gauge the devastating repercussions of similar past ventures. For example, as major US industries horridly stood in attentive support of Hitler's Nazi-coup post the 1933-Reichstag fire, the infamous 1952-coup in Egypt was similarly contrived to materialize within 6 months of $\boldsymbol{M B}$-US engineered July 26 blaze of Cairo's Jewish stores. The $\boldsymbol{M B}$ perpetuators were well shielded by their implant within the Wafd liberal party, the Wahhabi minister of interior Fouad Siraj Eldin. As of that time, the 1952-Wahhabis grew fervently in strength to claim the 9/11-WTC. Most recently with devastatingly negative repercussions, the US strategized for the Arab Spring which was poorly delivered by Haj-Obama. As Sadat was; Haj-Obama is a Noble Prize Laureate with unhidden flare of flattering the core of Wahhabism, viz., 2016 religious-adolescent remarks to the Islamic Society of Baltimore. Nonetheless, as much as Sadat and Hitler, his parental histology mystified his political aspirations hence were well calculated for a brief dominance on world's platform. His particular amalgam and the CFS prompted the poor deliverance of the Arab Spring as the societal rhyme of 2011-2013/ Egypt was different from the $\boldsymbol{M B}-1952$ coup colonels, indeed. It is our contention: Haj-Obama - the pale copy of Sadat - and H Clinton's grade would be at best a mentally anemic copy of TE Lawrence and an intellectual dwarf of Gertrude Bell respectively.


Environmental pollution, applications of pesticides, herbicides, food additives and chemical weapons

It is an absolute waste of breath to entertain any of the bombastic ridicule of the ignoramus I-in-C regarding the current life-threatening environmental malaise and necrosis that turned chronic and is almost irreversible. It is rather advantageous to nature and humanity to highlight scientific means of renewing the already depleted natural resources vis-à-vis the absurdity of "it is a Chinese conspiracy". To make things worse, the title factors are behind the exponentially elevated proportion of newly born babies with debilitating physical patterns together with cerebral insufficiency and general environmental ruin. Reviewing wealth of published data pertaining to humanitarian and environmental 
causalities perpetuated by the USA, this presentation is an urgent call to physical organic chemists to take the mandatory task of priming nature to its original format, if possible, at all. Most recently, in a 10 y time span, 1961-1971, the USA showered Vietnam with $\sim 72$ million litres of herbicides, $\sim 60 \%$ agent orange among others. By all accounts this is more damaging and toxic than Ho Chi Minh's communism! Besides the estimate of 1.6 millions' human causalities; estimated 20 million square meters of commercial timber destroyed; 135,000 hectares of rubber plantations; 124,000 hectares of tropical shrubs were extensively obliterated in terms of soils and nutrients' erosion, concomitant losses populace's nutrients and freshwater fish, as a result of water's intoxication, lipophilic dioxin contaminants in mothers' milk precipitated physical and neurological deformations in suckling infants and high incidents of miscarriages, contracting cancers, etc. Besides water and soil pollution, livestock and wildlife are among the serious causalities. The damage was not the accidental by-product of war, but part of the attrition strategy which deliberately aimed to drive the peasants into the cities in order to deprive the National Liberation Front of a population and food base, and safe jungle havens [28]. The Middle Eastern reckless adventures of the USA is leading to the chronic intoxication of nature and the uncompassionate dislodging of the occupants, denoted refuges, from their milieu to a totally different environment of discrimination and refusal. In effect, erratic and forced dislodging of these occupants are the carrying vehicles to second-generation pathogens resistant to known remedies and disfigured dogmatism ready to soak the arid psyche of occupants of the new environments with interpretations of murderous melancholies.

\section{Deliberate damage of nation's infra structure}

Heavy seasonal rains of 2017-18 overwhelmed Egypt to create havoc and restiveness among the populace, indeed. That was an opportune circumstance to the $\boldsymbol{M B}$ to rejuvenate their rancid call for a theocratic state. First, they had to flare a general state of resentment towards the secular government, best on the account failure to manage the flooding rains and consequences therefrom. Unhesitatingly, $\boldsymbol{K} \boldsymbol{K} \boldsymbol{K}$ thugs jammed the public drainage and sanitary pipe works with cement powder. Thus, municipalities' sewer water ways were indubitably jammed to have filth overflowing all over streets and alleys of major cities. This $\boldsymbol{M B}$ sadistic maneuvering led to many health dilemmas and high mortality rate among the children; as pathogens resistant to known remedies were released together with disfigured bombasts of rancid dogmatism. This was primarily schemed to soak the arid psyche of occupants with interpretations of murderous melancholies.

Besides the many 1000s of individuals were brought to early death, sadism of the $\boldsymbol{M} \boldsymbol{B}$ thugs knew no boundaries. For example, on July 5, 2013, in their blind support of the popularly deposed Mursi, they cruelly echoed their frustration by shoving a boy off a $7^{\text {th }}$ floor building to his death at the street level. Proportionally, substantial ecological damage took place in major cities, Upper Egypt villages and the Delta communities, as well. Typically, the right wing Wahhabi supremacists inflicted arsons on public and personal properties (the Notre Dame Paris, New York historic Church in
Manhattan that is home to the New York Liberty Bell, etc.). The most notorious was Rabaa Al Adaweyah which the Egyptian army amazingly contained in few days with minimal loss in human lives on all sides.

\section{Toxic munitions cause of baby deaths and deformities in Fallujah}

In December 2009, 170 children were born at Fallujah General Hospital, 24 per cent of whom died within seven days. Threequarters of these exhibited deformities, including "children born with two heads, no heads, a single eye in their foreheads, or missing limbs". As a reference, data for August 2002 records 530 births, of whom six died and only one of whom was deformed [31].

A French national birth-defect registry and biological menace of the Gulf war confirmed 250 tons remnants of ricked DUM continue to release depleted uranium to contaminate the soil of the Gulf war's fields. The incendiary ruin to the environment and humans post this reckless war [32] is expected to last for decades with preposterous damage to the wildlife, ecosystem and DNA-integrity of the newly born [38]. Recently, clusters of children born with malformed limbs in three rural areas in France [33] were identified. Each cluster has three to eight children with malformations which include children with missing or deformed arms and hands. It has been proposed; limb malformations could result from exposure to environmental pollutants and toxins, i.e., pesticides and herbicides that are used on nearby farms.

\section{Hypothesis and Interpretations of The Data}

The Arab Spring plot was primarily weaved to whirlwind (a) the dogmatically intoxicated Middle East, (b) the importation of the Taliban to catalyze the disintegration of Yugoslavia (c) expedite the down fall of the Libyan clown, (d) inaugurating the Dogmatic-Führer Mursi as the president of Egypt and (e) arranging for the Egyptian Wahhabis' cluster of Rab'a al-Adawiya slums/ Cairo to abort the Egyptian-ladies' cultural revolution, 2012-2013. With the least possible violence 2013 revolution has shortened Mursi's presidency to 9 months and riddled Obama's Arab Spring. In desperation, he contracted an ex-pow JS McCain to harvest peer's sympathy while visiting the detained Mursi and other Wahhabi thugs for purposely committing crimes against the State of Egypt. By comparison, a similar war of contrasting ideologies, that is the 1861-1865 US Civil War conflict left 620,000-750,000 soldiers dead and the yield of its current fermentation is the southern supremacists, etc. Most recently, the 51 days federal and Texas law enforcement siege of the Branch Davidians, Waco, resulted in death of 76 Branch Davidians including David Koresh himself [42]. In brief, the 8000y civilized Egyptian Ladies trimmed Haj-Obama's weight to its original value vis-à-vis the elimination of the Roman general, Gnaeus Pompeius Magnus [34] at the gates of Rakoda (Alexandria), 48 BC.

A blatant example of exaggerated variances of environmental dictates on the psyche of related populace is the thin passage of the English Channel that is separating two nations each with distinct heritage but driven by fundamentally different societal agendas; the 
UK versus France. Undoubtedly, the first wasted Oliver Cromwell's toil (1599 - 1658 [35]) whose exceptional impact did not last his expiry and the second nation bestowed the world with Liberty, Equality and the Fraternity of Napoleon Bonaparte (1769 - 1821).

Although, the current thesis of "Post Freudian Moses and Monotheism. The Eclipse of the Dawn of Conscience Egypt, the 1928 implant of Dogmatic Aberrations, Environmental Necrosis and Mutation of Tropical Diseases" is as many of our manuscripts were articulated much earlier, we lacked the drive to circulate it. It was (i) bare of the supporting scientific data, (ii) visualized as a pipe dream at a time the world was US-molded to stand in attentive Hosannas to the Camp David's mongoloid peace drama and bestowing the Noble Prize Laureate to a confirmed Nazi-Wahhabi, Sadat, and (iii) considering Hollywood's ghastly Hosannas, it was a total futility to reveal Sadat's true dogmatic intentions naked to the anesthetized West. In effect, it was obvious to Egyptians familiar with the mutilated and despicable psyche of Sadat's miserable childhood, his manipulation and placement of extremes, i.e., obdurate Begin and naïve-liberal Carter, as the Midwives in aid to his world-wide Long-Range delivery of $\boldsymbol{d e}$ novo Kalifates. At this point of time, we found it appropriate to submit it for publication as (i) Wahhabis left their characteristic "blood- stained" trade mark in many corners of the world and (ii) it was possible to build up a supporting wealth of date regarding the mental and medical integrity of occupants of the two most notorious ghettos in Egypt, Zabbalein and the Necropolis [18].

Therefore, we are publishing an alternative interpretation relevant to the contribution of the social failure, injustice, characterization, increased illiteracy and DMC to environmental erosion and evolution of de-novo genotypes of diseases. The apex of societal injustice and characterization manifested itself when government officials and internal news media busied themselves to spin a favorable interpretation to the infamous Cairo's crime committed on October 2011. According to item 6, WikiLeaks [36] a knowledgeable individual relayed, Badie and other leaders of $\boldsymbol{M B}$ are extremely concerned over the growing violence in Cairo. They note that during recent attacks against Coptic Christian community in Egypt, the $\boldsymbol{M B}$ and SCAF worked discreetly to ensure that the military and security forces did not intervene forcefully to protect the Copts. Furthermore; Subhi Salah, a lawyer and former Member of Parliament pointed out that discussions between $\boldsymbol{M B}$ and SCAf regarding the Copts was relatively simple, because "both sides were not concerned about the fate of Christian Copts".Specifically dealing with Maspero's massacre, the Egyptian $\mathbf{M B}$-offiocials displayed absolute disdain to the minimally accepted norms of civility and ethics. On October 2011, in response to a staged peaceful sit-in protestation against social injustice and characterization in front of the Maspero television complex, the army officers intentionally drove their personnel carriers to crush protesting civilians. Thus, their bodies were flattened to street's asphalt. Instantly 28 were massacred and more than 212 were injured. Most absurd, US officials who habitually sermon and lecture foreign leaders on specificities of human rights and freedom, Hallelujahed the 1989 Tiananmen Square and mourn the lost civil liberties of Tibetans, Haj-Obama called on the Egyptian civilian and tank-driven junta generals, to show restraints for the sake of Egypt! Moreover, in a lukewarm communique, timidly Haj-Obama hardly raised a rebuking comment on the 2015 massacre of 21 Egyptian by Libyan Wahhabis. Albeit, his early education in Indonesian madrassas may justify his muteness and vague stand, academic queries were prompted to rationalize his suspicious silence [37]. May be it was a mute silent support to the Taliban proxy fighters in Libya. Not very Surprising, the US ambassador to Libya was massacred without moaning or tears vis-à-vis the non-stop reporting on the Lockerbie event. The three incidents are absolutely unacceptable heinous crimes. Nonetheless, by all means the three monstrous incidents are the expected ferment for the hidden-adulterous love affair of the Westerners and Wahhabis. With some inevitability, this never ending political rationalism on the genesis of militant Wahhabism in Libya which called for these three heinous crimes point to the stepparents complexity, H Clinton and Haj-Obama. Most pertinent, is the (i) plenty of time the US-buoyed Wahhabi executioners had, in the heat of the Libyan sandy desert, to dress in spotless clean dark outfits and dress the victims in equally well ironed orange dresses and (ii) source and who supplied the executioners with these ironpressed - dry-cleaned - outfits and modern US-armory for this rare Hollywood opportunity (Data, Figures 5e-f)?
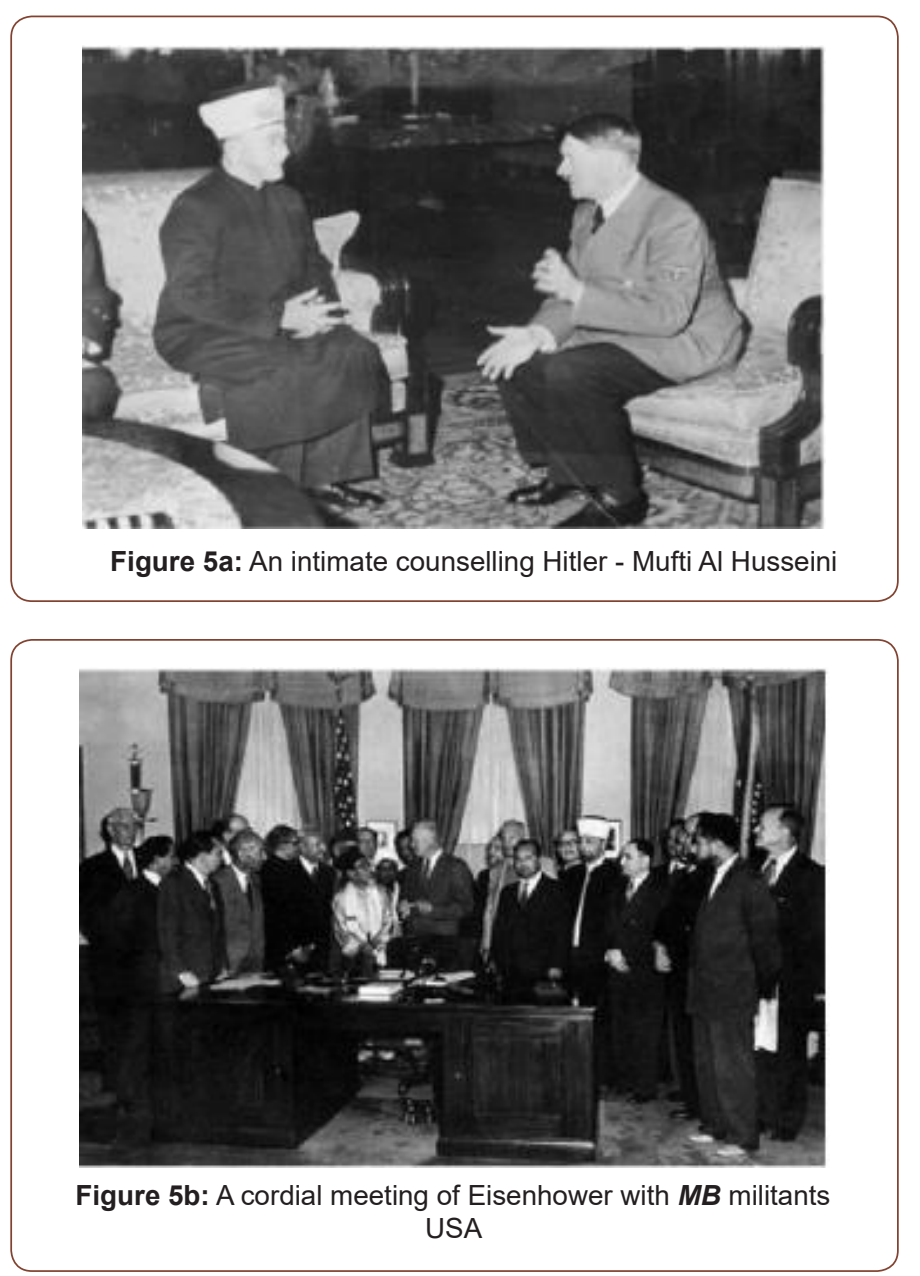


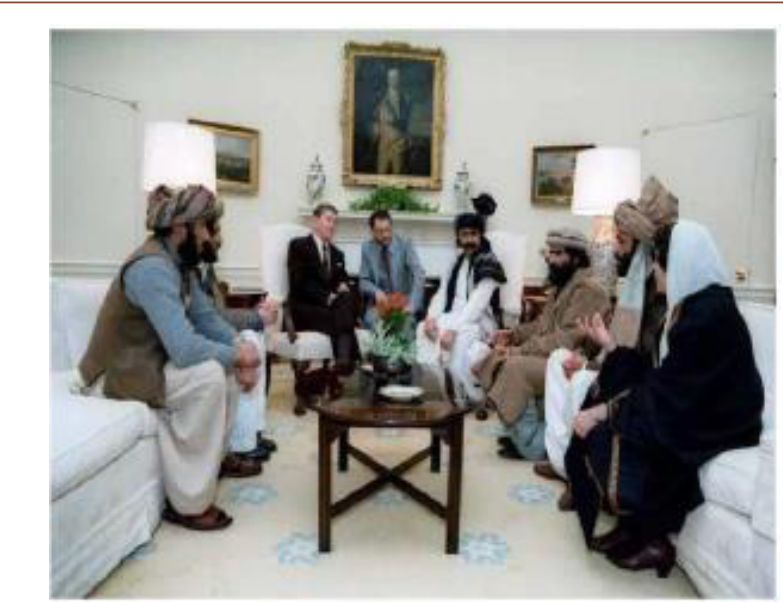

Figure 5c: Taliban counselling Reagan at Oval Office

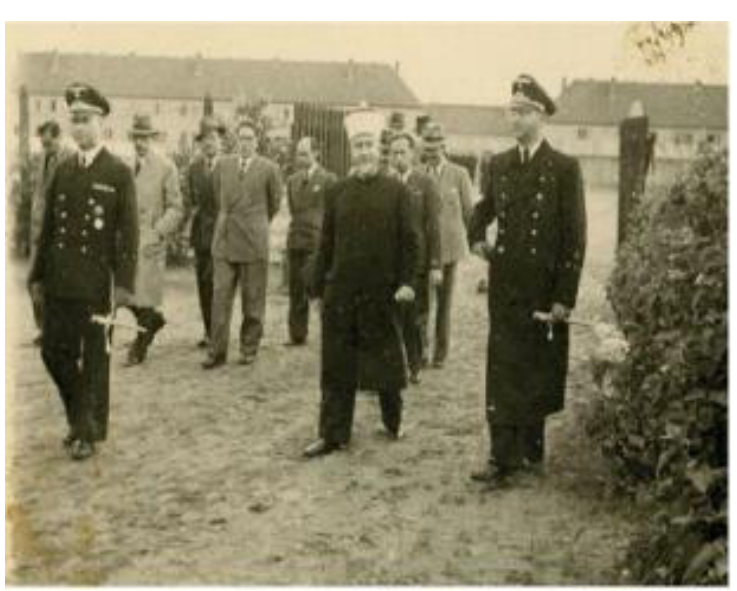

Figure 5d: Mufti Al Husseini inspecting Nazi troops

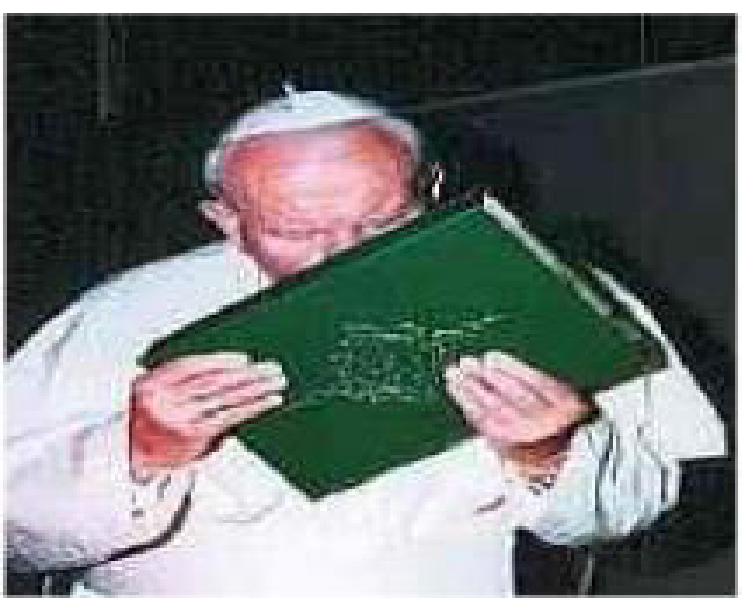

Figure 5e: The Reagan's pontiff showing respect

Incidentally, Eisenhower's incubation of the dogmatic extremism did coincide with the general malaise of the prevailing societal ethics and values of the Western nations. Briefly, the 1939 Nazism - the unapologetic reincarnate of the $622 \mathrm{AD}$ original format - was perfected into the 1953's McCarthyism-Hooverism's inquisitions [37]. Although polished and thinly lacquered by democratic procedures, the 1953 dark-ages remained a street-justice which (I) evoked the true protocol for the 2001 Supreme Court Coup, Post 1963-68, which blatantly ovulated the 2001 political labyrinth of the WTC. It is safe to speculate that these three intellectuals would have spoken in favor of human rights for all regardless of extracting political gains, dogmatic-maneuvering of the oil-rich tribes to stage local wars, Iraq, Kuwait, Iran, Syria, Afghanistan, etc., for the ultimate monopoly of energy resources, etc. The Oval Office assignments of Jihadists were extrapolated to nonsensical exaggeration. Human values were prostituted when Reagan not only labeled the Taliban's as freedom fighters but worse was his theatrical dedication of the most refined scientific technology, the 1982 space shuttle Columbia, to their caustic aspirations and dark corners, viz., Taliban's lashing, stoning, and decapitating females in public. At the White House, he confirmed absolute naivety and political myopia of his one-trackminded fixation. Melodramatically, called Mullah Omar and his bearded comrades: "These gentlemen are the moral equivalent to the USA founding fathers [38]!" In effect he equated the brilliance of John Adams - the modern equal to his Roman predecessor Marcus Aurelius - to Mullah Omar? In this framework, we find it absolutely biased to compare the genius of the Ancient Egyptians who tailored a prosthetic feet replacement to Egyptian labor who may had his/ her feet amputated while building the pyramids (Data, Figure 6a) to the Hollywood's cuddling of Bonzo (Data, Figure 6b). In summary, it is a pointer to the current declining of the Western World's intellect while precarious events are swarming every continent. By comparison in 1798-1801, the young General N Bonaparte, understood the mental malaise of the Middle Easterners and should he had the opportunity at the time, he could have positively terminated the threat of the Turkish Kalifate to save the world of the extra mental anguish over the Turkish's mass massacre of the Armenian.

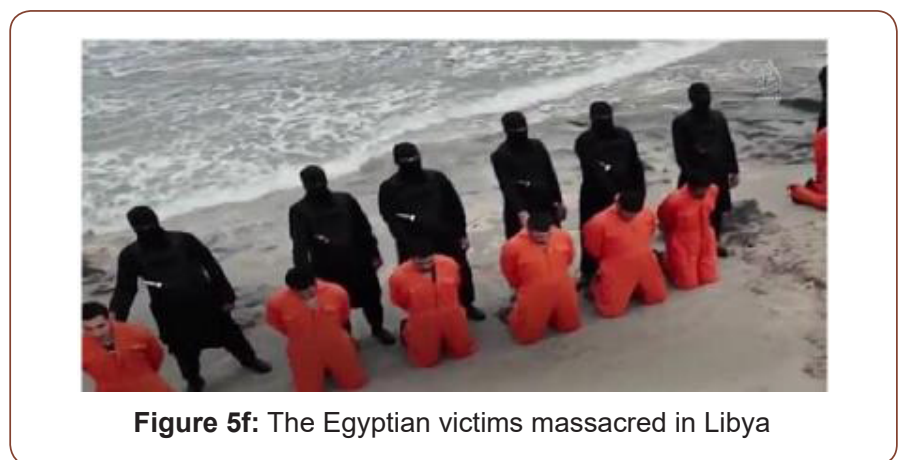

Assuming accurate and correct media analysis and reporting, the very same gentlemen "Reagan's freedom fighters" demolished the WTC. Regardless of the many circulating conspiracy theories, Sadat had his priorities hidden in his dark corners when collaborated with a well US-orchestrated surge of Wahhabism within the arid milieu of Afghanistan. To the US, recruitments of Jihadists in Afghanistan was a justification to (a) the same post WW-II broken record of military deployments closer to the Russian boundaries and (b) the extraction of the Afghani's natural wealth as previously mapped by the Russians. However, to Sadat, it was an opportunity to internationalize his version of Nazi-militaristic dogmatism. Ironically, (i) Clinton imported the Afghani Taliban to aid the dissemination of Yugoslavia according to religious boundaries (39), Similarly, the Taliban were marshaled into Libya 
to support the local dogmatic- $\boldsymbol{K} \boldsymbol{K} \boldsymbol{K}$ to topple the clownish empire of Gadhafi (39). Later on $9 / 11$ the same very militant Wahhabis demolished the WTC with substantial causalities. US Wahhabism metastasized to occupy many second ranking offices in Washington DC during the presidency of Haj-Obama and (ii). This is reminiscent to the UK at the top of the worlds' pyramid of power believing the sun will always shine the Empire. To secure the Empire's highway to Indian trade, the Turkish Kalifates of Uthman ought to be dismantled from within. Therefore, the trio, Mr. Hempher, Gertrude Bell and TE Lawrence were prompted to tailor the Middle Eastern political milieu in favor of a radical synthesis Wahhabism. The British Empire finale was the 1956 war and its fate was sealed by the same very militant Wahhabism. Currently, London became Mecca of Europe as Wahhabis reduced it to an isolated island. To make things worse, they knocked the door of one of Buckingham main bedrooms. Similarly, Hitler entertained 1000 years for his Nazi establishment. However within 6 years of a parallel trade of doctrinal melancholy, Germany was eviscerated to many plots. With the rise of Middle Eastern Wahhabism, the civil liberties of women and leading secular figures were compromised in Egypt and Tunisia. In this absurd political predicament and uncertainty chemists have all the providential right to query the political dwarfs: why charming US youth and Western ethics into utter misallocation of funds in protracted wars against previously US-tailored al-Qa'aeda of Iraq and the Taliban of Afghanistan? rather than allocating these tax-payer funds to provide free medical care for U S children and the elderly, free education for the youth, humane shelters for the homeless, etc. Funds are wasted in the Hollywood theater- wars of the Liberation of Kuwait, desert storms and bribing the corrupt theocracy of Mursi, chieftains of Afghani tribes, supporting the Taliban in Libya, and plowing the Middle East to be the fertile crescent of fanaticism, etc.!

The intrinsic greed of the multinational conglomerates; pharmaceutical, food industry, oil companies and militaristic adventures had irrevocably intoxicated human's psyche and ruined natural resources. However, the Maître d'hôtel offered unpalatable rational: the issue of natures' intoxication and placing limitations of gas emissions is a Chinese conspiracy to halt the progress of the USA, as a prelude to rape whatever is left of world natural resources by the same very conglomerates. The MIC should carry the main bulk of environmental restoration as the main contributor to environmental necrosis through wars and destabilization masqueraded by flashy slogans as of The Falling Domino Principle of Eisenhower [40] and Obama's Arab Spring. The conglomerate of aggression opted differently. À la J Geobbles, Hollywood tailored episodes that were pregnant with sadistic apathy which ultimately precipitated an exaggerated ridicule of glorified violence, e.g., the Expendables 3, into the well perceptive psyche of 10-20y old youth. The optimal ridicule was the conclusion of the movie; without a scratch, few young and old well-built legionnaires, including one female defeated a well arrayed army of opponents. The bare reality is; according to Wikipedia, the US causalities in the Korean and Vietnamese wars were 54246 and 58209 respectively. The finale of this particular episode was a blatant justification for street-justice that is an absolute anti-thesis to the rancid saga of ethical supremacy, democracy and respect to the rule of law. The head mercenary took the helmet of an internationally elected Judge, thus claiming he is "The Hague" to justify executing his opponent. With available armories in the streets of USA, mentally imbalanced returnees of Iraqi, Syrian, Afghani wars and Abu Ghraib torture camp would justly claim the "The Hague" complex to execute opponents and/ or spray bullets, thus killing streets' passers-by and school's children. As a precautionary measure to circumvent probabilities of societal outbreak of violence, the (PTSD [41]), psychological management of the returnees is deemed essential vis-à-vis Hollywood's mass psychological sublimation, Expendables 3. Worse, the circulated portrays of interrogating the prisoners of Abu Ghraib were indicative of psychologically unripe guards and knowingly recruitment of individuals loaded with aggression and mental aberrations. We should apologize to the reader for referencing these aggressive portraits as a pointer to improper attainments of guards' sadistic satisfaction/ depraved libidos while physically mutilating prisoners' sex organs. These figures are a typical pointer to a Freudian model pertaining to the conjugation of sex and violence, viz., US-females sadistic abuse of male prisoners at gun point. Paradoxically, assailants are claiming moral superiority. This is indicative of (i) repressed sadism which may invite elaboration on possible domestic prevalence glorifying the culture of violence and aggression in the USA proper, (ii) veiled neo-Nazism, equal to males enacting veils on females in the name sanctity, (iii) synonymy with failure of ethics and zoophobia and (iv) prompting the vacuolization of ethically-cirrhotic and redundant fatty deposits into the psychological extracts of the North American youth. This observation may rationalize the current elevation of abhorrent crimes in US cities? Thus, dealing with daily dilemmas, it is obvious the youth are anointed with the grace of violence in lieu of reason and logic, i.e., manicured with patriotism and anaesthetized with false heroism and patriotism, à la lemming rodents; they were driven happily into mass suicide in the bottomless lagoon of dogmatic fundamentalism. Lemmings are small rodents known for periodic mass migrations that can end in drowning.

Abu Ghraib is a case study in absurdity. It was established by the US to house prisoners of their deserts' adventures. They were never questioned and readied for court trials as the Nazi leading figures à la Nuremberg, November 20th, 1945. Nonetheless, they were tortured to be portrayed later as victims to whims of sadistic male/female prison guards, officially described as bad apples! We may differ, as these officers are at best diagnosed as individuals with recognizable depraved sexual inclinations. How feasible is it to commit this blunder at the "National Security" level? It is not feasible to account for the behavior of some of these guards on possible contraction with PTSD. Individuals' harboring this particular syndrome portrays well-characterized symptoms which would disqualify them from their posts at Abu Ghraib. PTSDindividual document irritable and aggressive behavior, reckless and self-destructive tendencies, exaggerated startle response, problems with concentration, persistent fear and anger or shame and guilt, all of which would not rationalize the committed physical 
and sexual violations against prisoners at Abu Ghraib. Shall we call then; Abu Ghraib saga is one of the many manifestations of the duel between the Re-Akhenatenization and Retro-Akhenatenization as of the Crusades? According to Yeshua, the ethical fabric of the Abou Ghraib's prison guards is qualitatively and quantitatively no different of Wahhabi prisoners. It is not too late for a mandatory UN scrutiny of Abou Ghraib's saga as the psychologically mutilated prison guards were abundantly harboring uncivilized traits and glaring ineptness of relating to societal imperatives as much as the militants of Isis and Da'aesh, nonetheless, barely of different names, color and dogmatic affiliations. By extrapolation, at all not different from the presumably UK-well-manicured-aristocracy who was Christie's auctioning robbed heritage [42], an ancient sculpture of King Tut. Said conclusion prompts two challenges

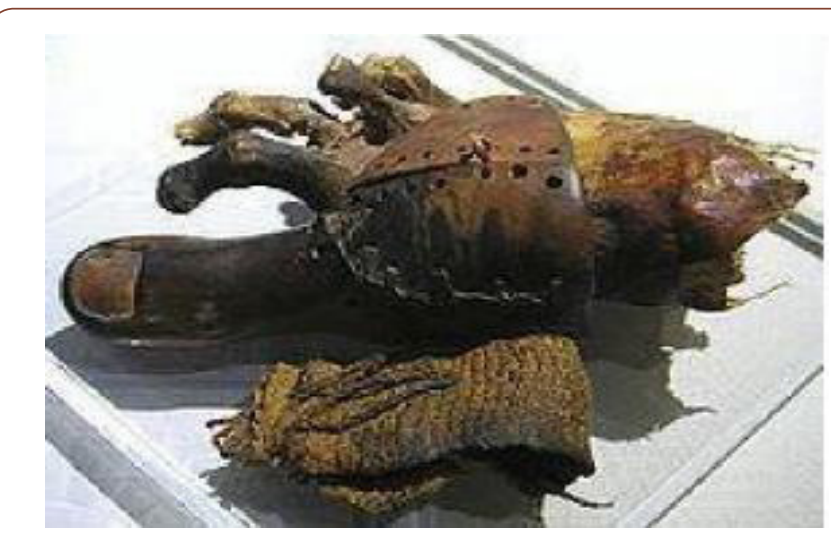

Figure 6a: An Ancient Egyptian artificial gadget for the amputees

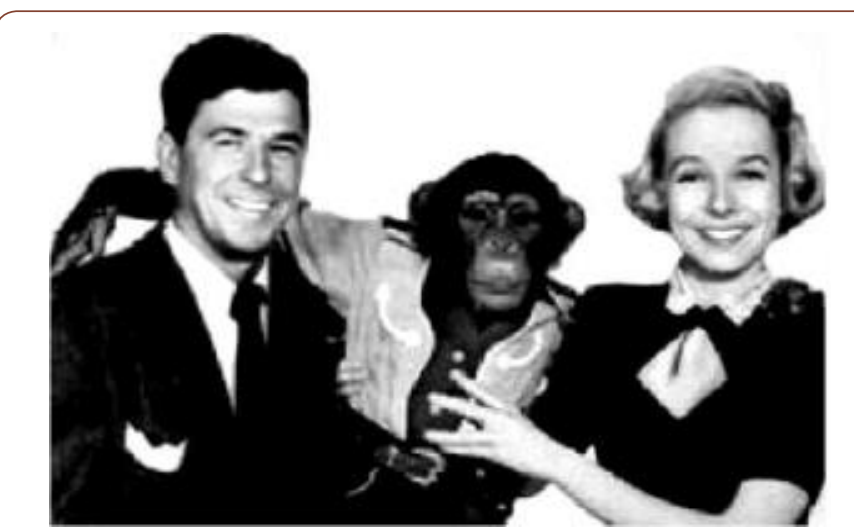

Figure 6b: Reagan and Bonzo.

A Plausible Rehabilitation of Environmental Necrosis induced by Retro-Akhenatenization? Environmental renewal is subject to scientific and unbiased non-political handling of causative factors which prompted the damage done of human's habitant [1] Considering the obdurate mentality of Isis and Da'aesh's Wahhabi militants is void of the slightest understanding the causative mechanisms of environmental ruin and procedures of renewal of the ethics of liberal-humanitarianism, a well-defined secular thesis of understanding authored by experts' psychologists, sociologists, MDs and scientists is deemed an urgent versus superfluous shedding hypes of Lucile Malandain's contributions [43]. Said contributions are anticipated to negate the political absurdity which soaked the Western world's fabric Post the plague of MacCarthyism and 196368 events. In an effort to debunk stereotyping of characteristically featured individuals as harbouring caustic dogmatic inclinations, L Malandain issued an unripe and naïve circular. This naïve circular eviscerated the issue of radicalism of its true core by advancing the shallow questioning: could the length of a beard or frequent prayers be litmus to individual's inclination to violent extremism? Malandain's Arabic is doubtful to entertain neither a quantitative nor a qualitative appreciation of the radically variant interpretations pertaining to the same very verse uttered by the elders! Instinctively, variances in interpretations are proportional to the personal circumstance and intellect of the interpreter as well to the subtle tribal hostilities and vendetta of the arid dwellers of desert. We dare say the basics of Islam were embraced differently by the Egyptians, Persians, Syrians, the Penta Polis (currently Libya), etc., according to the corresponding intellect of the state at the time. This may rationalize the many Islamic sects as much as in the two Orthodox families, Catholicism and Protestantism in Christianity. In view of the recent decapitation of the French teacher of history, Malandain should restrain the urge of publishing these trifles. Otherwise, in doctrinal zeal, L Malandain may opt to perform ablution if decided on a zoophilic session or drink camel's urine in lieu of medications, necrophilia and fiddling with next door males' nipples under the pretext of brotherhood? Although, it is not in tune with the purpose of current presentation, we found it of some relevance to readers with specific interest in variant interpretations of the Retro-Akhenatenization's theological fabric?

Retro-Akhenatenization in Full Display, Egypt 1981 - 2013: It was the years of convenience between the governments' various bodies and the retro-Akhenatenized militants. To their credit, Wahhabis and Jihadists took full advantage of Mubarak's' period of presidential fragility and corruption to germinate in every possible square of the nation's mosaic. The outcome of the chronic infestation of religious hysteria, confer with right or left foot should a believer walks into a water closet, hence precipitated drastic ruin to the Egyptians' characteristic civility and tolerance. By 2012, the nation was segregated at its religious divide which in turn amplified rates of sectarian crimes, ultimately ripped the delivery of the essential and basic fundamentals of education, medical care, daily sustenance, etc., to the dispossessed. All hastened the nucleation of rings of settlements of poverty around major cities - ghettos where crimes of passion, incestuous sexual relations, necrophilia, zoophile, predators targeting male and female children for sexual ends, etc., were stimulated. As detailed above, this intricate spectacle is an optimization to the political devices of fermenting poverty and provocative dogmatism. Together with the scarcity of adequate medical care and education, it was beyond the intelligence of the corrupt political pillars and their meek mental faculties, if had any to dilute it. Thus, insanitary enclaves of the dispossessed mushroomed within big city limits and Upper Egypt.

Collectively and most efficiently, the Egyptian ladies went on a massive June-July 2013 civil disobedience $a$ la the 1919 revolution. Thus, the issue was settled. In effect, the expedited demise of Obama's Wahhabi Pinocchio; Führer Mursi, was the shortest nonviolent Cultural Revolution in modern history. For 
example, (i) it took 16 years for the Chinese to mature their Cultural Revolution which lasted for about 10y leaving many disillusioned about its worth and (ii) for $40 \mathrm{y}$, Persians are tamed to a given interpretational spectrum of mullahs' Retro-Akhenatenization. With total disregard to violence committed by Führer Mur- si's thugs, the Egyptian ladies imposed their characteristic print of secularism. Thus, subconsciously they were defending their heritage of Akhenatenism and together with JF Kennedy were chanting Alan Seeger's I have a Rendezvous with Death:

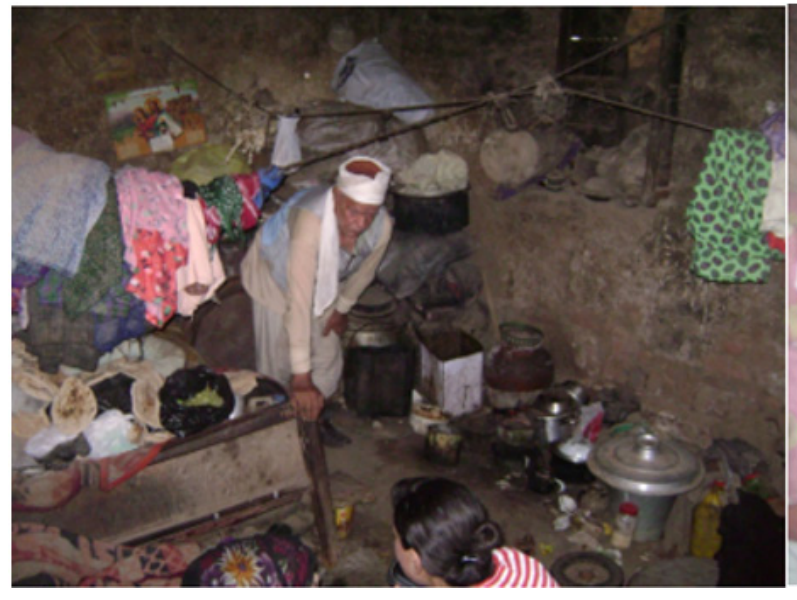

I have a rendezvous with Death At some disputed barricade, When Spring comes back with rustling shade And appleblossoms fill the air-

I have a rendezvous with Death

When Spring brings back blue days and fair.

It may be he shall take my hand And lead me into his dark land And close my eyes and quench my breath-It may be I shall pass him still.

I have a rendezvous with Death On some scarred slope of battered hill,

When Spring comes round again this year And the first meadow-flowers appear.

God knows 'twere better to be deep Pillowed in silk and scented down, Where Love throbs out in blissful sleep, Pulse nigh to pulse, and breath to breath, Where hushed awakenings are dear...

But I've a rendezvous with Death At midnight in some flaming town,

When Spring trips north again this year, And I to my pledged word am true,

\section{I shall not fail that rendezvous.}

Albeit Sissi his background is a strict military discipline, his wise approach of extensive dialogue with all shades of different thoughts rather than aggressive oratory (i) guaranteed intact and safe borders to Egypt, (ii) salvaged Egypt and its environment from a US-tailored internal strife and devastation respectively, $\grave{a}$ la the Iraqi, Syrian and Libyan models, (iii) appointed well qualified ladies to difficult ministerial jobs, (iv) opened a second water way to allow for opposite passing of ships round the Suez Canal less the 1956 war, (v) official tackling of societal dilemmas as the homeless of pocketed ghettos of miseries and environmental pollution and (vi) diplomatic unravelling of and alternatives to the RN water supply to Egypt and neighbor states versus Sadat's megalomaniac obsession of waving slogans of war with Ethiopia. All these achievements are

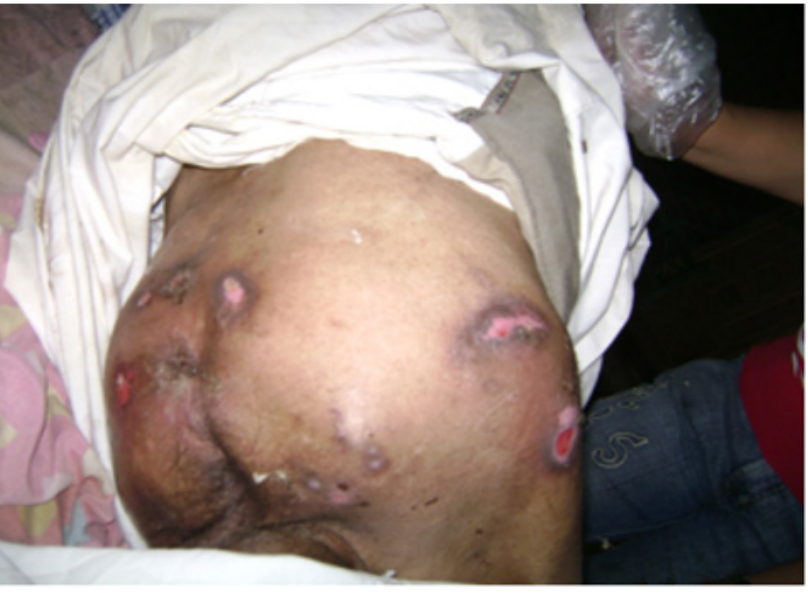

sparked by the triumph of the Egyptian Ladies' Cultural-Revolution against the ghoulish-trio "US-Turkey-Qatar."

In effect, without firing a bullet, the Egyptians shelved their deeply rooted dogmatic themes to surgically excise the 2012-US implant of Führer Mursi's cancerous' theocracy in the Egypt. Thus, peacefully: (i) frustrated one of the many drives of the US-PB which prompted the appointment of Haj-Obama to the Oval Office, and (ii) pointed to the disgrace of cataloguing him for the Noble Prize à la Tawakkol Karman, Sadat, Begin, Carter, El Baradei and most recently Abiy Ahmed. Ultimately, the 2013-Egyptian Cultural Revolution did pacify Wahhabis' radicalism in Egypt, Sudan and Libya, indeed. However, realistically religious trauma is far from absolute surgical excision of the national fabric. Accordingly, the total of fleeing refugees together with the negative penalties on health and societal standards of host European and North American laypersons was substantially reduced. The civilized world should be grateful to Egyptian ladies of 2013 to honor them with the Noble Prize vis-àvis Abiy Ahmed for stirring problems with the ever patient Sissi.

Haj-Obama travelled to Cairo to meet and win favor with the Wahhabi-tainted university students by reciting corresponding religious phrases as his fellow Sadat did earlier. Obama delivered a clumsy, crude and most boring 45-miutes of inhomogeneous' cut and paste phrases on June 4, 2009 entitled A New Beginning at Cairo's Al Azhar University [44]. Moreover, his body language and hand gestures during the lengthy speech at the Islamic Center of Detroit - Feb 2016 - was indicative of his desperation and chronic frustration of his 8y long failures to tame Wahhabism into the service of the MIC [45]. It is our contention, his colossal verbose, fat wordings and cheap oratories would yield at the best circumstance a rabies rats which do not deserve its weight of a cheap rodenticide. Altogether, as much as Sadat, a rational quest into his discourse is indicative of a tormented child who turned narcissistic to camouflage chronic juvenile delinquency. Both Sadat and Haj-Obama became presidents and first class pathological 
storytellers who were acutely incompetent to narrate truthfulness. Alas, rather than deserving calls for psychological attention, at critical points of time, Obama occupied the office of J Adams and JF Kennedy while earlier Sadat became the president of Egypt. Both shared the drive to promote international Wahhabism. The Egyptians patiently waited until 2013 to reveal their cognizance of Haj-Obama's Pinocchio-nose to daringly trim it (June 30, 2013) as their ancestors in Alexandria, Pompey 49 BC, and 451 AD of Leo's.

According to the CFS, à la his predecessors, Obama labored for the new masters (MIC) to purposely rescind his promise of withdrawing troops from Afghanistan and Iraq as claimed to materialize within the early two years of his first term. On the top of the rich natural resources of Afghanistan and Iraq, both countries are amenable basins to breed Wahhabism to the service of the fat-cats; namely, the magnates of MIC, GMO, food-pharmaceutical conglomerates and crude oil. Within a span of 8 years Haj-Obama inflamed more religious-feuding and conflicts of opposing religious and political sects rather than imbuing tranquility. According to his early indoctrination at the Indonesian madrassah, in a brokenlike record Obama parroted: "Islam" is synonymous with "Salam alaikum" that is "Peace be with you"! To start with an Arabic linguist with modest I.Q. knows it well: the word "Islam" does not connote "peace or Salam" but rather implies Submission to the latest monotheism; the Retro-Akhenatenization. On the other hand, the word "Salam" is a greeting call as in "Marhaba and/or Hello".

Most likely, the stunning failures of the militaristic adventures in Afghanistan, Iraq, Syria, Libya and Yemen catalyzed the notion of appointing a president with tight hybrid-cultural similarity to the nomads. Ultimately Haj-Obama was the ill-fated Democratic presidential choice to settle as possible "the monopoly of the nomadic oil resources in favor of the USA". That is to lure the most notoriously backward Middle Eastern nations to plummet deeper into the lagoon of retro-Akhenatenized dogmatism tailored by $\mathrm{Mr}$. Hempher, G Bell and TE Lawrence's. To appease his vanity, HajObama's modeled his pit of Wahhabi scorpions beneath a flashy banner; the "Arab Spring". Amazingly, Obama's Spring has left behind millions of cadavers, rivers of blood of the minorities, exodus of a multitude of women and children refuges, exponentiation of second-generation infestation diseases, environment's unsettling, etc. This Lawrence-like gamble was expected to yield new lucrative market spots for the sale of the stored and rusty second-hand US weaponries and save on soaking the nomadic desert with blood of US troops but failed.

What is next? Currently, it is deemed essential to circulate our thoughts and plead the clerics to distance themselves from Hempher's Wahhabism in a clear language and action. This is a due process as of 1798 general Napoleon's pierced the Ottoman's darkness in Egypt and Syria. Entertaining a positive hypothetical conclusion to the Napoleonic quest at that distant time, it would have limited many wars and conflicts, saved the Armenian and ultimately preserved the environment's integrity unscratched as possible. It is an urgent, however a peaceful overture to lay grounds for a non-profit round the table's in-depth discussions with worldwide $\boldsymbol{R e}$-Akhenatenized authorities of different dominations. Proceedings of the proposed round table's brain storming must adhere immaculately to the notion: How to confer the available treasure of humans' spectrum of pious thoughts which were paved according to specificities of contrasting environment to the maximal benefits and better life for all. The ultimate yield would be peace, common understanding, tolerance, appreciating divergences of religious thoughts and open channels of common respect to the current wide range spectrum of individualities with characteristic aspirations, human rights and freedom of expressions. As well, it is an urgent issue to irrefutably settle the definition to the most controversial and provocative notations, e.g., Jihad, Dhimmis, Mushrikoun of Dar ul-Harb versus believers of Dar ul-Islam. It is imperative to redefine of the Wahhabis' ridicule of denoting the USA aid to Egypt as "a long overdue "obligatory Jizyah" to be paid by Western Crusades to the believers", as well. Incidentally, Westerners and Christians in general are of the belittled status: "the Infidel worshipers of the Cross!" Provided positive outcome, we are suggesting a round table dialogue between different proponents to (i) minimize probabilities of wide-spread plagues of religious venomous hatred, dogmatic neuroticism and destructive anxieties, and (ii) maximize on fair streaming of crude oil without bias to all nations. An example is the non-stop mass media and daily periodicals' vocalization of religious melancholies over an Egyptian court delivering the death sentence against perpetuators of a silly and no-class movie "Innocence of Muslims". One of the victims who dived freely in the nostalgia of denouncing the "Innocence of Muslims" was Mursi, the theocrat. This particular event was a heavenly sent option to Mursi to confirm his withdrawal into the safe and tight Wahhabis cocoon. Alas, while reveling at the US-arranged theatrical-UN hosanna; both his body language and immature reactions betrayed the excruciating experience of his years of imprisonments in the Mubarak's era. Again, the question is: why should the USA, a country leading in the analytical psychology of PTSD-individuals, post long years of imprisonment as POWs in Korea, Vietnam and the Middle East, strive to have a mentally incapacitated individual, Mursi, to occupy the seat of the Egyptian presidency? This arrangement would make it possible for the American ambassador in Cairo to fill the presidential shoes while Mursi et al were busy devouring rich meals at kitchen's floor of the presidential palace. His utter mockery and feverish sermon in the love of the Prophet at the UN's supposedly clique of the politicalknowledgeable, expedited his disgraceful demise. On his departure, Mursi's Au revoir Cadeau to the Egyptians was Kerdasah and Rabaa Al Adaweyah!!!

This Dark Age Middle Eastern's dogmatic mosaic was remotely manipulated by US-political novices whose main concern was to rally the Nazi dogmatic clan to the support of their besieged dogmatic Führer-Mursi against all shades of Egyptian secular intelligentsias, minorities, liberals, socialists, communists, etc. By comparison, at $2 \mathrm{~K}+12$, the Obama-H Clinton clique showed to distinctly score lower I.Q. grades vis-à-vis the elders of RetroAkhenatenized militarism, in terms of an early invocations turned wild according to mental aridity of the environment together 
with an aggressive pace of life which was dictated by shortages of daily supplements. Currently, the Westerners are not immune of the consequences of their triggered technological advances. In brief, affordably cheap and efficient transportation of humans and thoughts in-between various continents made the world a little village. That is the desertification of Western cultures, erosion of environment and evolution of second-generation genotypes of bacterial and viral diseases are more feasible.

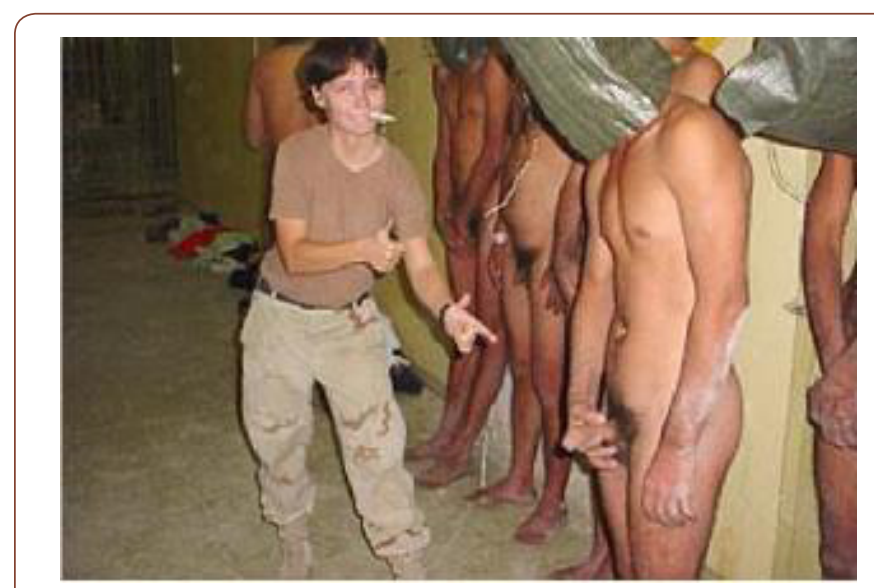

Figure 7a: The disgrace of the USA at Abou Ghraib

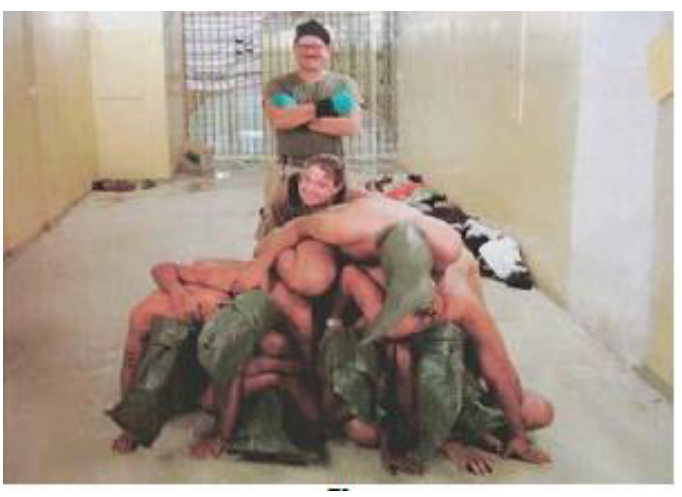

Figure 7b: The disgrace of the USA at Abou Ghraib

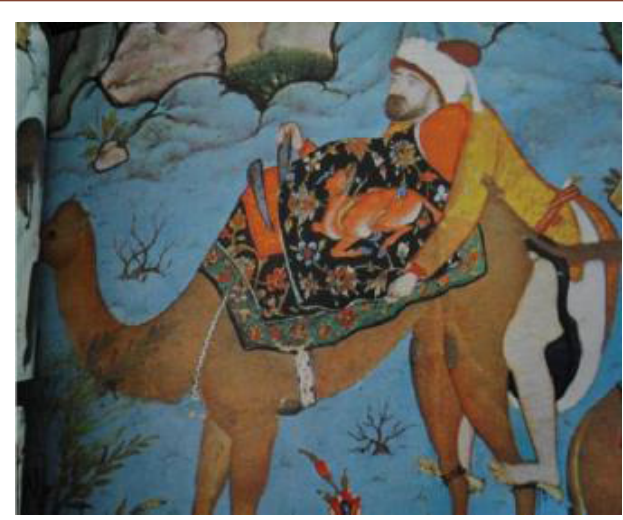

Figure 7c: Persian Art depicting mating with camel

The Expected Cultural Decadence of the Western Civilization: Currently, 15-18 million Egyptians are with different dogmatic preference. The revolutionary council of the 1952-US-Wahhabi coup reaped their sustenance by agitating the populace according to dogmatic preferences. As deliberately envisaged, the Egyptian minority was marginalized at all levels. Thus, an internal dissention was ploughed to guarantee de-novo US hegemony of the area. The subject of the present search is a thorny one, indeed. However, the abundant tolerance of this scientific media made it appropriate to print the epitome of the Egyptian decline from the heights of the most refined Pharaonic/ Pharaonic-Hellenic cultures to the present state of irreversible decadence. Scrutinizing details of the Egyptian model may help Western scientists' formulations of a viable mechanism to salvage what is left of their culture? provided tilting closer to mechanisms of societal justice of JF and RF Kennedy.

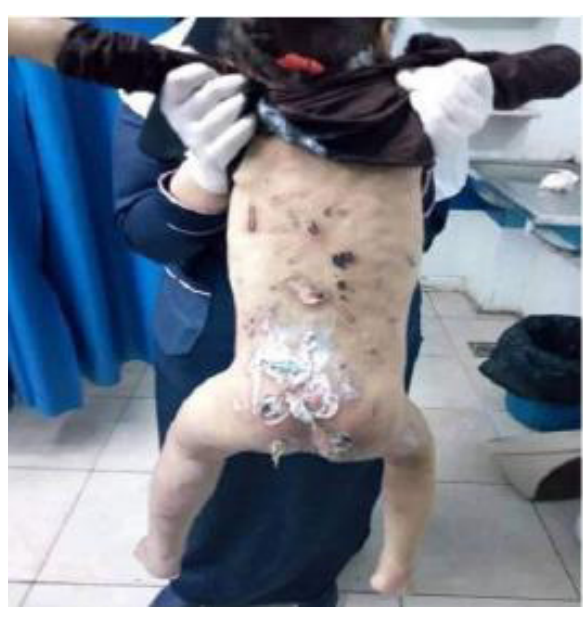

Figure 7d: Abused female baby Egypt

The dominance of militaristic dogmatism over scientific rational, e.g., a cleric suggested against liver transplant as it delays the pre-arranged time of the diseased encounter with the Creator (www.youtube.com/watch?v=B623afH7zfI). Furthermore, in a hand written $\boldsymbol{M B}$ communique; electricity was claimed to be from the devil, it is healthier to urinate and/ or defecate in a desert open space as the elders did and education is a redundancy as believers have all in the Book, Others commended against artificial insemination as sinful (www.kaheel7.com). These persuasions left $\sim 80$ and 25 percent of Egyptians plagued with illiteracy and HCV-4b respectively and infestation of a wide range spectrum of tropical diseases and males' feminization. Albeit the initiation of femininity, i.e., spermatogenic arrest is rationalized in terms of genetic factors, we found it proportional to environmental intoxication with pesticides and herbicides [18]. Due to the spermatogenic arrest, $8-12 \%$ of newly married couples, men failed to impregnate females. The outcome is male/ female erroneous addiction to sildenafil or cheaply prepared local analogues and a wide array of societal dilemmas, specifically physical mutilations of women and abuse of children cascaded within a male-dominated schizophrenia of religious piety. To top it, Egypt is on the verge of topping the world's crucible that is fermenting second-generation de novo bacterial and virally mutated diseases resistant to known medications. Albeit Egypt is characterized by the HCV-4b genotype, recent observations are strongly suggesting the mutation of HCV$4 \mathrm{~b}$ to a new genotype [18].

Recent and distant historical records of AD 641-nomadics outbursts of theirpredictablecultural holocaustare well documented beyond negation. This is best illustrated by scrutinizing, the burning of 7000y of Egyptian culture - the library of Alexandria - purge of the Assyrian, Persian, Byzantine cultures; and the devolution of the 
jewel of Hellenism - the Pentapolis - to Gadhafi's Libya. The most recent incidents were (i) the 2001 demolition of the world's oldest Buddha statues in Bamiyan, Afghanistan. Demolition was done for the pious purpose of cleansing the country of Hindu's heresies? Did these militants entertain the thought: why should Allah in all of His Endless Wisdom grant His creatures the capabilities to excel and shine in artistic visualizations, e.g., the pyramids, obelisks, the Bamiyan Buddha treasures, etc., to Contradict it later as realized how these objects would soil His Fidelity? In effect, He precipitated international dilemmas and wasted the believers' breath calling for the demolition of the products of humans' ingenuity? Worse, on March 1979, a beautiful monument of 800y old Egyptian past, the church of Qasriyyat al-Rihan/ Cairo's old quarters was burnt. Nonetheless, USA-fat cats opted to negate these obvious litmus indications as were addicted to sniffing nomadic crude oil. In their utter wisdom; pillars of the US-PB were incognizant of the tequeyah's gesture of their collected-notorious Wahhabis; Wassel, al-Qaradawi, al-Raawi and a delegation of the Organization of Islamic Conference to dissuade the Afghanis of their threat to demolish a 1700y historical Buddha's monument, March 10, 2001. In good faith, if the top US advisors to the president have any relevant education at all rather than availing "All What You Can Eat for 5 \$" they should have considered the causative factor for the earlier defeat of the USSR in Afghanistan. That is the USSR troops who combated the Afghan Wahhabis, were drafted from the neighboring Asiatic regions closer to Afghanistan, have laid down their arms in favor of Afghani brothers. Thus, this appointed blend of Wahhabi imams issued an appeasing communique to the effect of repudiating the destruction of the Buddha monument. This communique momentarily rescued the US from taking the difficult stand of international teaming in favor of protecting a world's cultural heritage. However, we see it differently: The $18^{\text {th }}$ century and current Westerners practiced the same timidity and cultural disgrace that is basically equal to the demolition of the Bamiyan Buddha treasure and burning of the Library of Alexandria. Worse, the US and European upper middle class of the 1830 practiced the witchcraft of drinking a homogenates of ground mummy's powder in liquor for therapeutic treatments of various ailments. Mummies unwrapping were a social event, as well. Giovanni Belzoni robbed Egyptian mummies and artifacts on behalf of the British Council to Egypt, Henry Salt, later stolen mummies were burnt in the wintertime to provide heat to their lodgings! In summation, it is the holocaust of Egyptian heritage. Two examples of the very many; (i) the monastery of Sultan in Jerusalem was bayonets-sieged by those who never owned it and was given to those who never deserve it. Significantly, in the Middle Eastern dogmatic blaze, the Jewish state managed peaceful accords with Sudan, Morocco and United Arab Emirates. Humbly; the optimal maintenance of these peace accords and toiling for same with other neighbours is more urgent vis-à-vis carrying the unnecessary burden of a dispute among two Orthodox families. Specially, in civil disputes between private citizens, it is usually the courts which will referee ownerships not the political baseball bat of the state with harmless monks; and (ii) with all of the typical arrogance of the finger manicured British aristocracy; in an auction of the Turbaned-London; Christie has sold a stolen property of the Egyptians; a 3000y old statue of Pharaoh Tutankhamon. Although, lacquered differently as one is denoted "the terrorists" while the opposing side is "the cultured Westerners", both shares the common dark corner of "better than thou" of Mufti Wassel. Whilst (i) Wassel condemned the destruction of the Bamiyan statue; his favorite topic is the endless "reiteration of the disembodiment Egypt" of its valuable heritage on the account of sinful stone manifestations of the Almighty, (ii) not only the UKfat cats sold the stolen $3000 y$ old Egyptian heritage for $\sim 6$ million $\$$, but were also selling UK newspapers to the nomads. In the first place, it is most appropriate should these characters who are unceasingly weaving the rancid accusations of the dictatorship of Chairman M Zedong/ President V Putin consider: thrice the Russians saved the West, from the Mongols of Asia, the Nazis and US-synthetic Wahhabis. By all means, the socialistic dictatorships of Chairman M Zedong/ President V Putin are more humane than the dictatorships of the military-industrial complex-pharmaceuticalsfood industry multinationals.

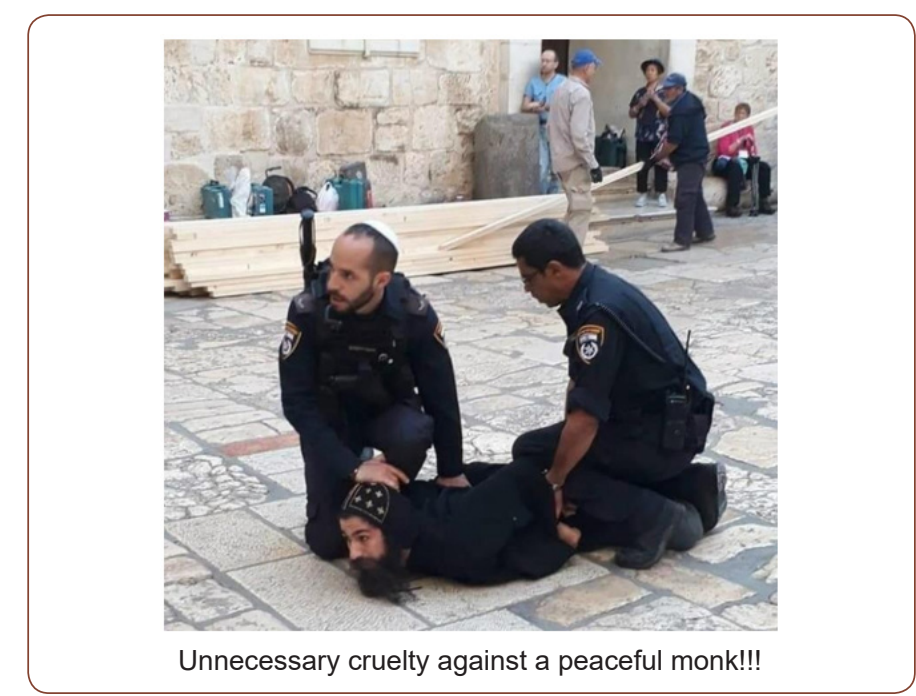

Intentionally, Western laypersons are kept void of comprehending the intricate consequences of drafting the nomads' dormant-dogmatism into the service of the fat-cats as of Eisenhower's MIC to Haj-Obama's tackling's of emotions of specific teenagers by twisting and polishing quotes which soaked his Indonesian psyche. However, Westerners laypersons woke up too late to acknowledge the hard reality: those who destroyed old monuments, such as a Buddhist treasure, $4^{\text {th }}$ century Egyptian Churches, etc., would not hesitate to demolish the WTC, burn the Notre Dame Cathedral/ Paris, etc. Thus, long range damage, in response to protracted militaristic adventures in Afghanistan, Iraq, Syria, Libya, etc., was negatively inflected on the already deteriorating US economy and the rusty societal cohesion of remnants of a narcotic-consumed nation, in terms of exponential increase in homelessness, unemployment, intellectual-poverty, etc. The driving force that is shunting the Taliban's to behead women in public arenas, aberrations of males to mate with a goat <documentingreality.com > forum > army-camera-catches-afghan..> is of the same energy pool which incited the Nazi-Wahhabi thugs in Upper Egypt (2013) to shout victoriously "Allah w Akbar" while sexually assaulting kidnapped females. Absolutely, Western females 
would entertain the same fate when the right circumstance avails itself. The pertinent question is: What is the wisdom of exalting Allah the great and Akbar for the lawlessness of males' act of sexual rape of a helpless female of different thoughts? The Tiananmen Square incident was the prime manifestation to the political Dr. Jekyll and Mr. Hyde. The incident is stretched to fit every occasion and all public events and political gathering, viz., Intelligence 2 presentation: China Friend or Foe? Possibly, a long-range design that is expected to disintegrate China based on religious dissentions à la Yugoslavia? If materialized with consequent environmental necrosis, collapse of air quality, multiplied events of breakup of ailments, etc., it is most likely the outcome of the short sidedness of the black/white cat approach of D XiaoPing (1961). Consequences of implementing the white/ black cat economics; the irretrievable damage done to the Chinese environment and populace which is solely the responsibility of the US fat cats abuse of low salary Chinese working force with total disregard to environmental pollution and human health. The pertinent observation is when these cats, regardless of color, turned fat of eating too many mice; its next preys were the Chinese populace and their ancient societal values. The current Maître d'hôtel-Chinese dilemma is one of the very many malaises of the white/ black cat strategy. In other words, the impact of the current US-Chinese cold war is a devastating environmental ruin and the collapse societal ethics.
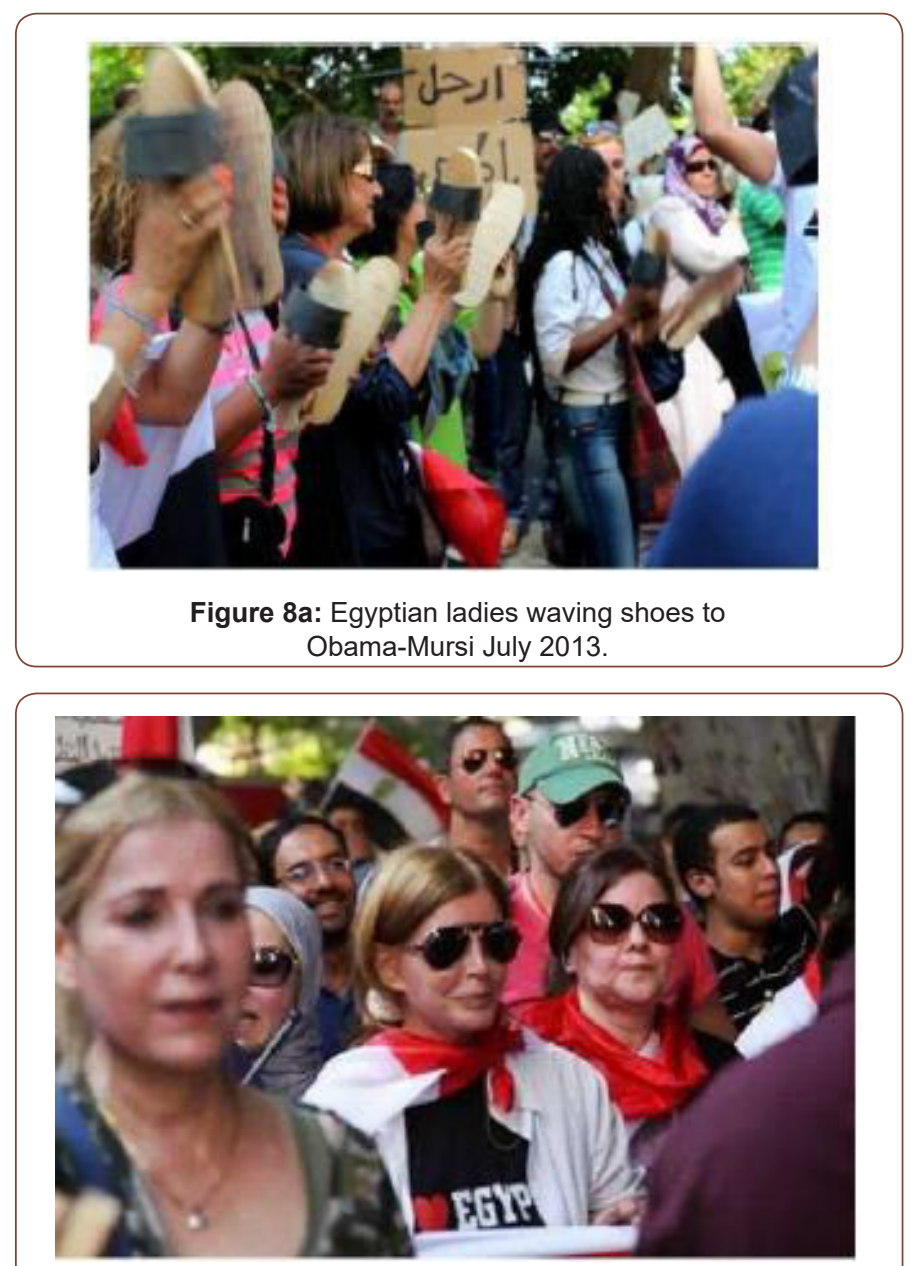

Figure 8b: All Egyptian ladies marched against Obama-Mursi.

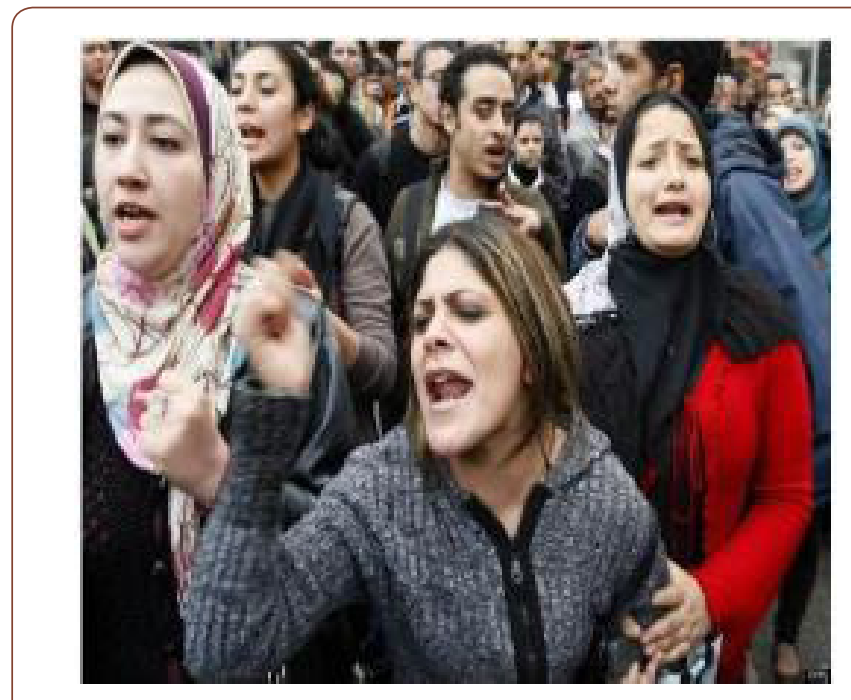

Figure 8c: June-July 2013 civil disobedience.

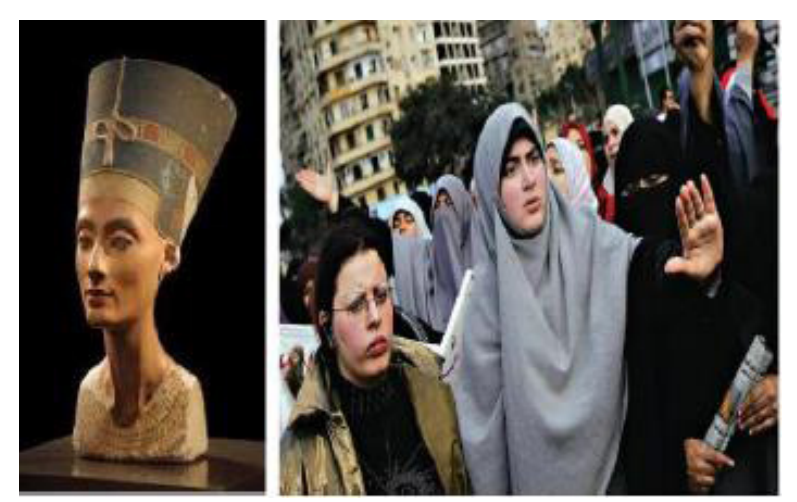

Figure 8d: The ladies of Egypt in memory of their Queen.

In contrast, Haj-Obamas' administration willingly failed to rebuke, with the least, if any protestation at all, the vicious acts of the Ku Klux Klan-Wahhabis' street justice (lynching of a Shiite Egypt 2010-13 Data, Figure 4b-d) as ignored the Armenian holocaust (Data, Figure 4d). That was Raba'a al Adawiya's Mississippi Burning and looting of Cairo's environment and assassinating opponents. With certainty, sheering Allah w Akbar while beheading and/ or dismembering individuals suspected of minor crimes and sexually assaulting females are indicative of the core ethics of their mentors' (Obama) fabric. Worse is; the readiness of the US-fat- cats to spell the blood of the underprivileged of other nationals to crystallize their crude-oil agenda. Thus, it is not difficult to envisage (i) the barbaric acts of 641-bedouins post metastasizing into conquered civilizations to cultivated nations and (ii) the bleak fate of Western -industrial nations should Nazi-Wahhabis assume control of their realms. Regardless of the perpetuators, victims are the by-products of crude oil greed. It could be summarized, laypersons of New York and the civilized world found remnants of the demolished WTC towers in their laps while humanity was busy internalizing the demolished sensations; many hands were busy wiping the tears of the victim of the fat-cats' greed. To manicure their claws, the fatcats embarked on long-term Hollywood's TV theatrical episodes with intimate allies; the $\boldsymbol{M B}$, Taliban, Isis and Da'aesh! 


\section{On the exponentiation of the environmental necrosis and intellectual cirrhosis}

In a typical response of an innocent void of comprehension of the intricate political-religious setting of the nomads and to reciprocate the favor to the MIC for his Supreme Court's appointment, the war president went into a poorly calculated venture of costly wars in Afghanistan and Iraq. The evil jinni who demolished the WTC and world heritages had his lamp rubbed by (except for JF Kennedy) the predecessors to evoke the Wahhabi-1952 coup in Egypt, the '56, '67, Hollywood's 73 wars, and the delivery of the mongoloid Camp David's peace. In effect, said mongoloid peace accord failed to deliver the least expected; that is an official declaration of normalizing relations between Israel and the surrounding nomadic tribes, in particular the Saudis that is supposedly the agreement stricken with the founder of the Saudi dynasty (Data, Figure 9a) The reality is: the number of Israeli civilians and soldiers killed after the enactment of the Carter's mongoloid peace far exceeds the totality of the Israelis' causalities in all of the Middle Eastern Conflict. This gave the fundamentalists free mental meals and the opportunity to flame their hatred and recruit worldwide secular Muslims and disenchanted Westerners. Thus, strengthened their resolve to a wholly protracted jihad and tantalized their sensations to a wide range of rewards bestowed onto the deceased jihadists in the afterlife. These rewards include: (i) the most sensuous daily mating virgins with a ravenous lust and an organ that is always erect and does not bend Dahman Dahman (sound of forceful penetration [45]), (ii) sodomy of everlasting boys, (iii) rivers of wine and milk, etc. This is to finalize the takeover of the neoWestern Byzantine Empire by Wahhabis as Constantinople was seized by their nomadic ancestors; the Turkmens. Eventually; the daily functions of the created universal dhimmi enclave of whatever is left of the Western civilization would be the obedient attendant to the Turkic Khedewvi. Why not? The major by-product of the '67 war was Sheikh MM Sha'arawi. As intimate comrades in the culture of hate, aware of Sha'arawi's radicalization of Algeria, Sadat repatriated the Sheikh to galvanize Wahhabism in Egypt, thus consolidate his presidency. Alas, dogmatic radicalization of the passive Egyptians paved the way to the assassination of the Carter's meticulously sculptured pipe smoking prince of peace, Sadat whose life's span was dramatically shortened (but was expected) post the exportation of el Zawahri and other evil knights to Afghanistan. The Wahhabis implant claimed the lives of many Russians and, later, Westerners. Thus, civil values of Martin Luther were steadily compromised. In this context, US arms support has religiously driven the tribal sentiments of the Taliban's Wahhabis against the leaning-secular Afghanis aided by the USSR. That was the Afghanistaniztion to possibly expedite the dissemination of the USSR? Politically, that was a dreadful and erroneous calculation whose by-products were rather costly; (i) demolishment of the WTC, (ii) drainage of US morals and economy in desert wars in Iraq and Afghanistan which exponentially exceed the euphoria of dismantling the USSR, (iii) degradation of the war-consumed societal-fabric of Western nations, etc. Within a time span of $30 \mathrm{y}$, the very same blunder but shaded differently, denoted as the "Arab
Spring", was synthesized to bloat the Middle East at a larger scale! To start with, the mechanism of permeating support to dictators for life, e.g., the Shah (Iran), Sadam (Iraq), Nasser, Sadat, and Mubarak (Egypt), was principally architected to abort remote possibilities of Soviets' penetration into the Middle East. This is to deny the Soviets of possible leverage on crude oil and secure its abundant flow to the USA; by definition the MIC. Incidentally, the half-life time span of Middle Eastern dictators approached expiry. Thus, their lingering to reign over decadent Sheikhdoms became an obvious embarrassment to the very same architect of the US foreign policy. Same naïve architects had to evoke the dormant religious sentiments of the populace, Arab Spring? to the inevitability of toppling and/ or assassinating the anointed dictators. For example, the Iraqi 1958 coup, the 1971, 1975 and 1981 assassination of Nasser, Faisal and Sadat respectively. Post the Islamic coup in Iran, leaving the Shah to fade, Sadam was consumed to disembowel Iran; later he was 1991 eviscerated in a Hollywood's saga "liberation of Kuwait" which sealed the disintegration of Iraq according to 661 AD religious divides. The ecological disaster of the "Liberation Kuwait" was the unprecedented birth defects that were most probably hastened by the US-newly developed, under trials, weaponries; DUM and radioactive contaminants. Most likely, humans' tendency to commit violence is within our DNA descriptions as of Cain and Abel. Earlier to Kissinger's "Control oil and you control nations; control food and you control the people", to bring their opponents to surrender, the Romans and Assyrians were cognizant of the essentiality of grain stocks of their adversaries. Thus, their commands practiced the first military herbicide techniques to pollute environmental resources. Both, sowed salt into the cropland of their foes, making the soil useless for farming.

In modernity, within a time span 1972-1990, millions of Vietnamese occupants and 1000s of US, Australian and New Zealand service men developed cancers and other health disorders due to exposure to dioxin and Agent Orange. Anti-personnel mine devastated the Vietnamese population with lethal physical inadequacies and reduced rice, the locals' prime ingredient of sustenance by $\sim 50 \%$ [46]. Furthermore, mines reduced agricultural yield in Afghanistan [47], Bosnia, Cambodia and Mozambique respectively. Wildlife and domesticated animals were substantially injured by land mines as well. Back of an envelope calculation would accurately envisage the magnitude of environmental waste coupled with the most recent 1 million Rwandans genocide [48]. Environmental issues in Ethiopia and links to the Ethiopian economy that is ravaged by long years of major powers instigating internal conflicts could be assessed as well [49]. Furthermore, TNT's contamination of vegetation resources has proved to be poisonous to mammals, aquatic microorganism and fish [50].

The politics of maneuvering religious sentiments in favor of a given political agenda had a long-term blurred vision, indeed. Although, on the very short term, oil companies procured massive financial gains; the stability of the Middle East as the major supplier of oil is marred with great uncertainty, viz., Isis- astronomical sales of syphoned crude oil for $50 \%$ discount! Over and above minor 
remnants of theological founders of early Christianity, the populace of the Middle East is radically polarized into two religious rival camps; the Sunni and Shiite sects, viz., the Jan 2016 sadistic murder of a high ranking Shiite cleric Nimr al Nimr by Saudis and the 2013 lynching of Shiites in Egypt. Evoking Sunni-Shiite rivalry could spell worldwide environmental devastation; especially the nuclear Pakistan is principally Sunni in absolute sympathy with the Sunni bedouins while Iran, a predominantly Shiite state, is trying to get nuclear. On the long run, A pointer to devastating consequences of a Sunni-Shiite duel is the disastrous fallouts of the short-term Mursi's Nazi-theocracy in Egypt (Figures 4a-c and7d). In this context, it is most appropriate to recite, with minor modification:

According to legend, a wise bird raised the young warrior Zal, in her nest atop the highest peak of Damavanad. When he came of age, she gave him a plume of her radiant feathers to burn if he was ever in desperate need, and she should come to his aid. Pity, you seem to be fresh out of feathers. Although, Wahhabis bankrupted the US in arid deserts, the Maître d'hôtel is eyeing to engage Iran!

We are calling on the United Nations to entertain an International Day to commemorate the Egyptian seculars, Dr. Farag Fouda, M Daniel, K M Saeed, and others who lost their lives, brutally mishandled while defending secular values and human rights for all Egyptians. Implicitly, they arrested Sadat's scheme of universal Kalifates (Data Figure 10b). This would help the drive to alleviate the accumulated stress of Middle Eastern religious characterization; that is the sole product of UK's 1881 successful synthetization of Wahhabis' radicalism, viz., Mr. Hempher et al., to Haj-Obama. By all means, the utter failure of the Arab Spring was an Annus Mirabilis. The democratic rise of general Sissi to the Egyptian presidency has minimized world-wide possibilities of costly international religious conflicts and expected exponentiation of environmental disasters. Judiciously, he managed the safety of the Egyptians and the borders of Egypt. By contrast an email drafted by general Petraeus, NATO commander in Kabul to the Associated Press September 7, 2010 best briefs the emotional volatility which could spell disasters in Afghanistan and worldwide for committing an irrational act within the USA proper. He begged for an urgent wisdom of an intellectual leadership, "An American church's threat to burn copies of the Muslim holy book could endanger US troops in the country and Americans worldwide. Images of the burning of a Koran would undoubtedly be used by extremists in Afghanistan and around the world to inflame public opinion and incite violence."

The unripe socio-economic fundamentals of the 1952 coup officers did galvanize the tailoring of the mentally cirrhotictheocratic state in Egypt as envisaged by al-Banna, the first UK appointed murshid. Most likely, the defeat of Egypt 56 and 67 wars and the drama of 73's victory which prompted the mongoloid peace agreement were no coincidences. Earlier, the intellectuallyhandicapped 1952-thugs, happily glued to the fundamentals of Wahhabism, declined the peaceful overtures of Sharett for just peace. Thus, the chances of evading the dreadful consequences of three unnecessary wars were wasted. Incidentally, Sharett regarded vengeful killing as an emotional response-barren of any morality. In brief, lost opportunities, specifically post 1967 had maximized the emotional and psychological disfigurement of the populace. Thus, the believers earnestly embraced Sha'arawis' call for Allah's scheme of salvation, i.e., combative dogmatism and mental stagnation at the sayings of the elders. At the time, Sadat came to realize the time was not ripe to the laying of Hitler's mirror image of universal. Kalifates of Uthman, therefor, aborted Sharett's peaceful overture. To a modest psychiatrist's understanding; Sadat's anguished the "Attachment and Loss" and "Maternal Deprivation Psychology" syndrome [51] drove him to sabotage the nonviolent approach of Sharett. In conclusion, the DNA engraved-hatred polymerized into three defeats to hurriedly establish his universal Kalifates and terror and pencil the Camp-David dwarf as suited his dogmatic tunes.

The outcome was not only the mental and environmental ruin of Egypt but also the irreversible propagation of a well-established polymeric network of terror; the Taliban and Mujahedeen [51]. This macabre net-wok has already damaged a sizable portion of the US and European inner fabric at the usher of the and sermons of sheikh 0 Abdel Rahman, M Ben Musa Al Nasr and Abu Hamza Al Masri of New Jersey, Montreal and London respectively. Post the enlightenment 1963-68 era, concurrent failure of Western intellectualism and acute famine of uprightness among Western politicians prevailed. One of the major consequences was the failure of integration which prompted many jihadi-localities in the USA and Europe to call for the strict application of Sharia's laws! The most pertinent question is: who authorized the permanent residency status for these individuals in the USA, Canada and UK respectively? MIC together with the radical-capitalism, sponsored the political necessity of radical-Wahhabis to guard the interest of the masters. This political milieu of gluttony did buffer the metastasizing $\boldsymbol{M B}$ nascent elements in every corner of the USA and Europe. Thus, the budding of L Malandains' syndrome did loom [43]. The prevailing climate; the facile computer sharing of knowledge with a click on computers' keyboard, ease of communications and transportation together with the acute famine of political morals and the popolarismo of cow-boying the US-democracy has eventuated the popular no-substance and political vulgarism of Bonzo and the I-in-C (Maître d'hôtel). To a nationalist Egyptian, most likely the MIC and the PB provided the DNA of fossilized Wahhabism with a buffered medium to free-radically multiply. The yield was a congregation of militant Wahhabism with close narcissistic and unyielding stigma with the MIC. That is espousing the denial of the working class of their fair share of extracted wealth according to the promise that the heaven is for the poor and meek, both adhere to the principle of holly skirmishes to attain the nirvana of sniffing the nomadic crude oil? and supremacy. Inevitably time wise, the rhythm of violent events is exponentially shortened, thus hastening the disintegration of what is left of the already disintegrated US and European states of culture and ethics.

Post the 1952-Wahhabi coup; Egyptians with different threads of thoughts did develop many negative characteristics which were engraved into their psyche [52]. Consequences were the loss of zeal 
to excel and the joy of hard work. Their elders have to envisage over and above the broken record sermons of "prayers and fasting" a persuasive, however a defeated theological rational to attenuate their misery. They happily submitted to the control of these defeated theologies whose main thesis is the misery of Jacob. Mentally, they became the living-dead who are incapable and seriously void of the enthusiasm to palpate positive alternatives. Thus, their main theme became to sacrifice all self and material possessions of the world, including the nation if necessary, for a better afterlife. Their tapestry became a unique shade of a continuum of the sadistic elders at the one extreme and at the other end; they masochistically squatted in endurance to the daily abuse by various thugs, the $\boldsymbol{M B}$ and governments' officials. Thus, adapted to the well documented events of physical abuse and characterization with the same very pleasure their ancestral martyrs endured to preserve the faith. Why not? It is a blessing to carry the burden of daily abuse for spiritual salvation! They knitted themselves into a protective cocoon that is resistant to outsourcing of different thoughts of progressive theologies. Worse, they fantasized miracles as a substitute to hard work. In brief, they are an interesting case, of a perfect Freudian's experimental-model pertaining to dogmatic-induced mass-failure of attaining secular accomplishments on the account of the clericals' dictatorship of monotheism.

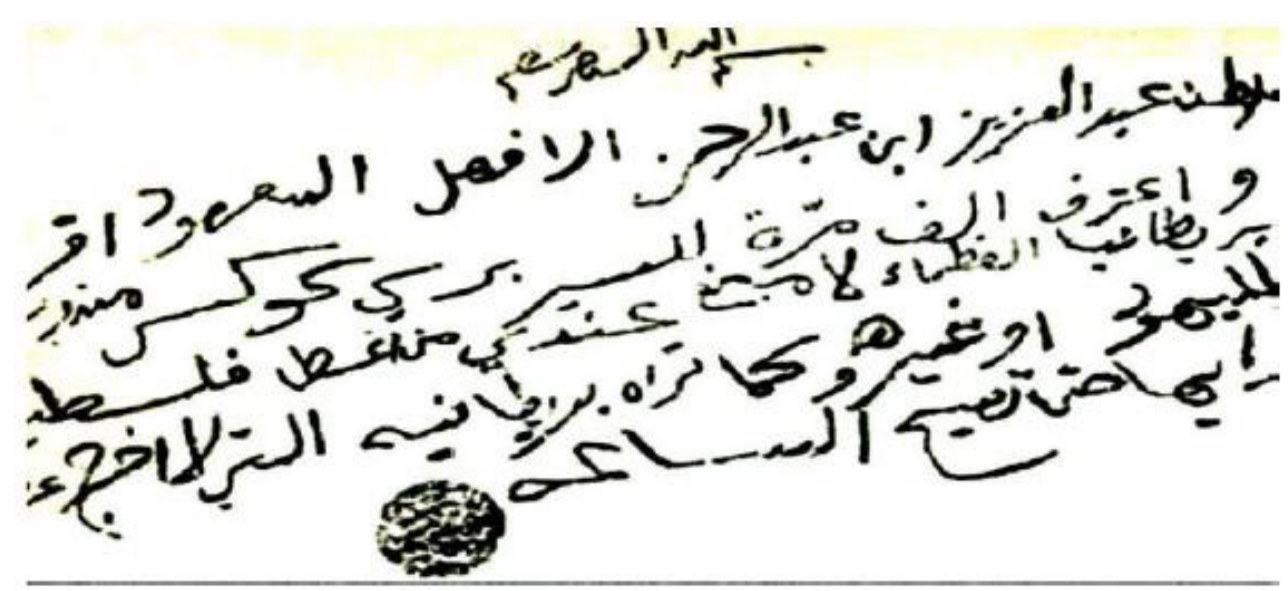

Figure 9a: A promise never materialized

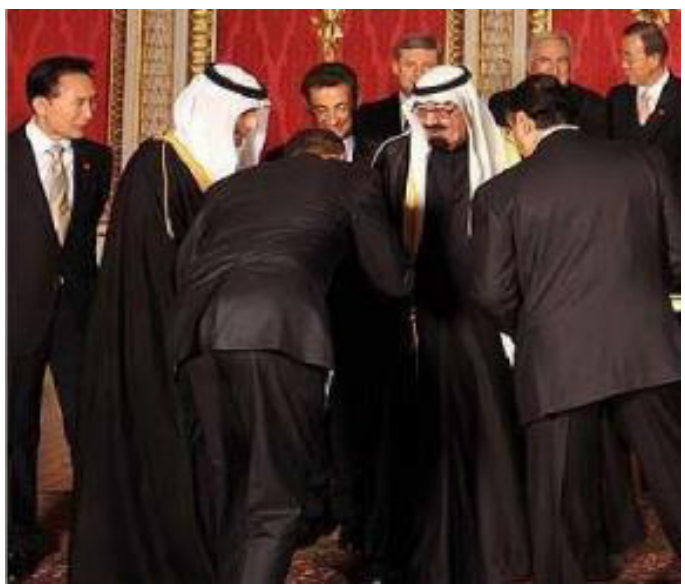

Figure 9b: Obama: Yes, we can bow.

\section{The political-dogmatic mental tapestry of the nomads}

Scrutinizing the available data of the Egyptian model post 641 $\mathrm{AD}$, a common nomadic pool of fascinating psychological dogmatic amalgam embracing violence, politics and sex, was recognized. This pool is best described as a sump that embraced the discharged pus of these infectious neurological aberrations and dogmatic militarism of the nomads. These accumulates were re-channeled to nearby unfortunate communities. Considering, the topography, genesis and oil-geopolitics of Mr. Hempher's Wahhabi dogmatism is a mandatory task. This is to evade further plagues of (i) dogmatic mental infections, viz., Paris September 25, 2020, Nice Oct 30, 2020 and Alexandria - Egypt December 11, 2020, and (ii) environmental erosion is subject to:

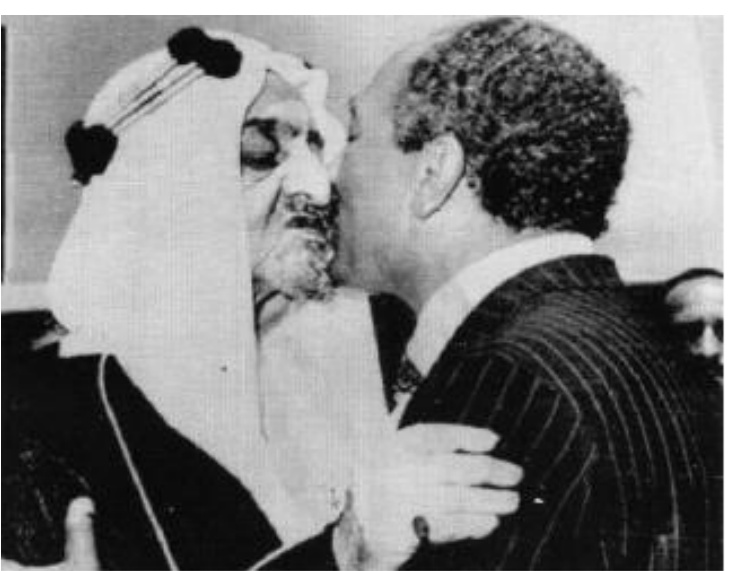

Figure 9c: Considering Obama 9b, Sadat was more dignified

- on site psychotherapy; medical disinfestation and psychological rehabilitation of the mental addicts to this pool, and

- $\quad$ deliberating rational responses to the lethal and biased trivialities of L Malandain [43]. It is mandatory to maximize the awareness of Western laypersons, at the scholar levels, of this pool's toxic ingredients. For example, adding this particular topic to universities' curriculum would ensure rational, positive dialogues and brainstorming among interested parties. 
We see it; mentally bankrupt nomadic-elders of said 641-pool are no different from the 2003-Western guards of Abu Ghraib. It is deemed essential to cognize the psychological and societal imbalance of Western victims and the underlying mechanisms prompting these Westerners to sacrifice their faculties to this dogmatic pool. Thus, their mental lucidity is eviscerated to the minimal possible. Concurrently, a special emphasis should be given to the cultural bankruptcy of Egypt, spread of tropical diseases; HCV-4b and poverty post the Wahhabi coup of 1952 colonels. The relevance here is; Egypt as it was in the past; the promotor of the Hellenic, Roman and by definition the Western civilization, is a valuable commodity whose safety should be the prime priority of the world's community. It is a fact: Sissi with great success is moving mountains of social rust to salvage Egypt of drowning into the lagoon of self-destructive accumulates of the past 60 years. Therefore, at the present circumstance of prevailing worldwide uncertainties, decency and abstemious calculated responses promote him to top posts as the UN chief.

As of the 1960's assassinations, the dominance of Bonzo's bedtime and the Maître d'hôtel et al., ultra-conservatism, obliged the withdrawal of the scholars of taking the leading role in advancing concrete societal collectivity as a primary defense against the preaching of Western nomadism. This is already subjecting the current population to the Hyksos-Turkic plague of the unethical manipulation of human genome. Naturally, the last two officers of the Wahhabi 1952-coup enjoyed close ties with the masters; Eisenhower, Nixon and carter. For example, prior to the expiry of his half-life time as a useful commodity, Sadat's image was a Hollywood TV-tailored pipe-smoking individual who toiled effortlessly to bring the bedouin-Israeli conflict to a peaceful conclusion. Similarly, his successor, Mubarak portrayed himself as the wise individual who is negating the fanatic Wahhabis and reluctant to get into war with the Israelis. These portrayals suited the US-PB for almost 30 years. However, the unexpected revival of Putin's Russia and the recognition of Mao's China as a super economic power drove the USPB to the crude oil's drawing board. In haste, a Sadat-like character, Haj-Obama was appointed to the Oval Office. Thus, a costly, however poorly schemed Arab Spring drama was implemented to signal the expiry of Mubarak. The Arab Spring conclusion was the falsified election of a mentally incapacitated dogmatic Führer, Mursi, to the presidency of Egypt. Mursi was in active contract with many diseases, e.g., diabetes, HCV-4b, range of tropical diseases, underwent brain surgery to remove a benign lump which plagued him with many side effects, e.g., speech stuttering, irrationality and PTSD. In the first place, these ailments should have disqualified him from running for the presidency of Egypt. Ultimately, the blunder of appointing Mursi as the US-Watch hound of crude oil fields to minimize on US militaristic involvements' in case of emergencies was synonymous with the 50y old blunder of the Vietnamization of the war in Vietnam. Both failed, however, the stunning failure in the Middle East has numerous unforeseen consequences to precipitate in later generations. It is rather possible to hypothesize; the following two steps mechanism
- $\quad$ in their wisdom, the US-PB came to the realization; the genesis of the current mass drive of Middle Eastern refugees into the USA and Europe is the climax of tuning the societal characterization and downgrading of others with different thesis within the 10 and 30y of Sadat's and Mubarak's presidencies, respectively, thus

- $\quad$ thus, opted for the dogmatic Führer's presidency to curb the migration and infestation of Wahhabism into the USA via cleansing the Middle East of minorities with different perspectives.

That was the second blunder of the Bonzos and Maître d'hôtels-likes as primarily failed to realize, (i) violence is neither a mutational nor a circumstantial event of modern day's political maneuverings but rather the antithesis of democratization in favor of dictatorships, and (ii) the abundance of the Nazi-gene within the biological matrix of the 641 foot soldiers is the norm that is impelled by the arid geopolitical tapestry of the barely habitable environment. The thermodynamics of this political-environmental equilibrium tipped the balance of anti-democratization in favor of the dictatorship of the Omnipotent-Kalifates.

Why not? As pertained above, the topography of the nomad's fabric was ingrained according to the aridity of an excessively hostile milieu. Thus, were denied the ease and comfort of life as opportunities of hard labour to extract necessities of daily life and natural resources, e.g., vegetation and animal husbandry as well. It is not surprising then; the notion of hard work was alien to them. Therefore, they were left infertile to communal life with characteristics abundant with dryness as the weeds of the desert soaked into the conceptual formulation of the Sumerian's Nazism. In the Ancient Egyptian mythologies these tendencies were depicted as promoted by the evil desert deity "Set". To them, humans are differentiated according to race, gender and fluency of the Assyrian-extract; Arabic language. Interestingly, according to Sumerian mythology, Nazi is a deity, one of the eight born to relieve the illness of Enki. He was the deity born from a god. Nazi was believed to be a man of crafts and mischief, of the ancient city of Eridu, what is now Tell Abu Shahrain, Thi-Qar Governorate of Iraq. He was the consort of the deity Nindar. Their lives were absorbed into animals of their milieu; camels and donkeys, i.e., they ate and closely intermingled with either. Accordingly, a spectral rituals were tailored, viz., Persian art portraying a human mating with a camel (Data, Figure 7c).

Most recently, the Middle Eastern political situation has exponentially deteriorated. It was baptized as a friendly promotion of the dogmatic mongrel Sadat to become Carter's assistant to export radical Wahhabis and remnants of Soviet's armory left in Egypt to aid the Taliban in duel with the Russians. Thus, Afghanistan was together anointed by a mongrel Wahhabi and a naïve preacher to ferment boundless webs of anti-Western sentiments and the premier importer of US war machinery and exporter of hate literature and violence to major North American, European, and Russian cities. In this context, a wise political scholar, Dr. Boutros Ghali, the ex-chief of the UN, was absolutely correct to call for a universal and worldwide toil to unravel the Somali's pivotal web of 
fundamentalism. Others differed as were already in preparations for the "Arab Spring" states. Thus, a novel multidisciplinary analysis, taking into consideration the dominance of the culturalethical factors of the political reality of the bedouins, is urgent. It is absolutely relevant to stress it again: the nomads are the product of the desert's heat and scarcity of water, food and serious education. Dominantly, in-depth re-education and psychological rehabilitation, is deemed essential to reformat their mentality that is fixated into the swamp of violence, sex and petrodollars to a more balanced version.

\section{The Common DNA Array of Violence; the Nomads, Nazis and abou Ghraib's Guards}

Although, the crude oil-\$ rich sheikhdoms are excessively rich, they are inflexibly congregated in various bigoted male-dominated clans and crazy-glued to the sayings of their elders. Thus, failed to realize on the account of nature's aridity, they were not only denied the: (i) pleasure of 'hard toil, say agronomics, animal husbandry, etc., for sustenance but also the (ii) lucidity of educated insights into the Freudian-nirvana pertaining the fair distribution of the extracted surplus of oil's wealth among the poverty stricken multitude [53]. To start with, they ought to humble themselves to the issue of learning from the Israeli's RO-technologies of fresh water supply. According to the literature $50 \%$ of Israel's fresh water supply is RO desalinated sea water which converted the sandy $84.75 \mathrm{Km}^{2}$ Eilat to a green paradise. The question remains: How feasible is it to rewrite nomadic males' DNA that is anciently optimized to the routine of scuffling to secure food supply (later denoted Jihad) and adapted a degrading attitude to females? At that distant time, the protocols of Jihad were a wise and an absolute necessity in synchrony with their arid enclaves. Rightly so, for protection; females were left behind during the Jihadi's scuffle of as femininity was a soft spot within the attacking or defending lines. As a reward, after long periods of skirmishes, wisely (a) males were permitted to mate with captive females of the crushed tribes but without impregnation and (b) return to their tents with a prior notification lest wives are caught in sexual intimacy. The $2 \mathrm{~K}+20$ most logical yields are (i) even though alien to the concept of social justice, nomadic generations as of 640 $\mathrm{AD}$ are tenaciously interwoven into the erroneous interpretation of elders' dogmatic melodies and (ii) most likely, the violence-sex amalgam is a common pillar with excellent matching receptors to the constitution of the nomads, the 1939-1945 Nazis and Abou Ghraib guards which upon stimulation would evoke comparable behavioral aggression? If correct; social imperatives of US- Goebbels' tailored adoration of violence and feigned political muscularity of the Maître d'hôtel and "cuddling Bonzo" ought to be recalibrated to the norm. Thus, it is scientifically demanding to identify the common factors which plagued this specific sector of Westerners to display the commonality of psychological aberrations with the nomads. Correctly, we are hypothesizing; it is very feasible the societal prevailing characteristics of dictatorships, incivility, loss of freedom of self-expression and rational criticism, melancholy of fear, and expected authoritarian reprisal etc., have created a nomadic milieu similar to that of 1939-1945 Nazi and Abou Ghraib's concentration camp! Nonetheless, the nomads' fabric is irreversibly soaked into these slums to manifest a unique devotion to the Freudian axis of sex and violence, say the 2013 deafening shouts "Allahu Akbar" of the victorious Wahhabi male thugs while sexually violating females in Upper Egypt. Any insights to why the Omnipotent should be over exalted for the rape of captive females by His believers"? Most recently, $5 y$ old baby girl, Jinny Mohamed Samir, was subjected to horrendous physical mutilation by her grandmother as burns, amputation of her foot, disfiguring of her vagina, etc., to cover up sexual predation of the child by her uncle.
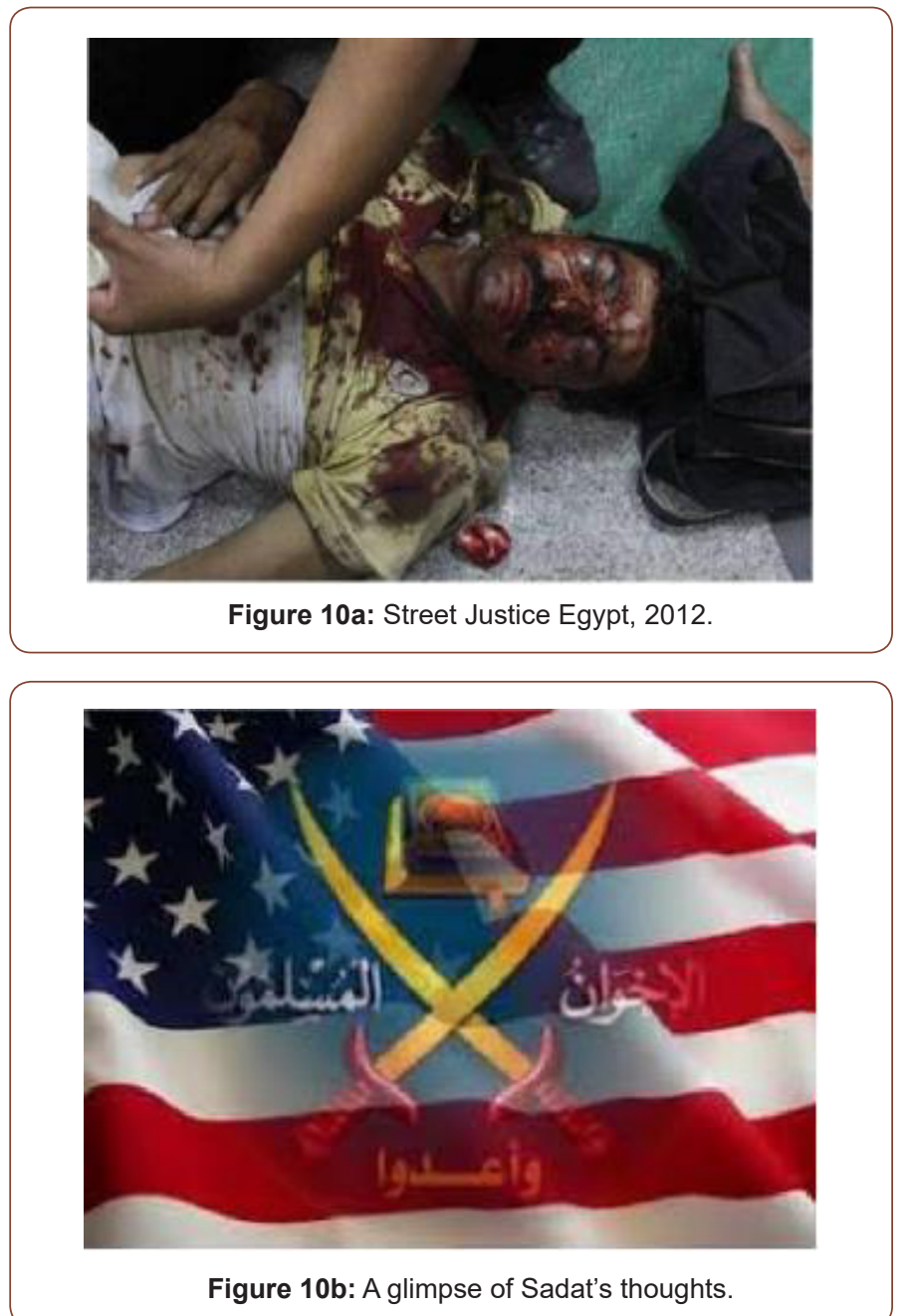

It could be stipulated: Wahhabis are willingly yielding their faculties to an intricate complex of a narrow dogmaticpolitical vision stipulated by the elders. Nonetheless, with all modern research facilities, available published literature and documentaries in libraries, they miserably failed to palpate the obvious; the enormous amalgamation of their threads with various plagiarized texts of other dogmas and mythologies of children's bed time chats of Aladdin, Scheherazade, Ali Baba and the forty thieves, etc. The most obvious impact of said inheritance is they became frozen in time and helplessly impotent to scan the possibly conflicting rational to the obviously fossilized psyche of the nomads as of 641. This is mandatory to untie their inhibitions at adopt Martin Luther conceptualization's of democracy as a humane substitute 
to their lusty and costly entanglement in the hate-killing fields of the liberation of Kuwait, wars in Afghanistan, Iraq, Libya, Syria. All these conflicts necessitated the US-expensive hatching of Isis and Da'aesh yielding the refugees' dilemma, the killing fields of whoever harbors different themes, sale of $50 \%$ cheaper crude oil and the psychological ruins of Abou Ghraib. Politically unbiased scientific inquiry into Abou Ghraib's saga is most beneficial as nomads own most of the essential commodity of the fat-cats and MIC addiction; crude oil.

Bernard Lewis accurately documented in a series of publications; the essentiality of dogmatic believes in the daily life of the political world of the nomads. Theme of his publications agrees with the thesis of current manuscript. For example, "the unquestionable obedience" to The Omnipotent and the Prophet is the priority of the faithful, as well. Thus, it was essential to elaborate on the details of this particular Retro-Akhenatenized pool of energy that is limiting the routine details of the faithful's daily life to the extreme of waging wars against the infidels. This pool of energy is rather different from the earlier Ancient Egyptian drive which led Pharaoh Amenhotep IV to formulate the first monotheistic doctrine glorifying The One Deity Aten - Akhenatenism -, King Gilgamesh of Uruk in Mesopotamia to build the ark, the Egyptians of Rakoda to formulate the creed of the re-Akhenatenized faith, the genius of Cyril and Dioscorus to non-violently preserve the distinctness of Egypt versus the occupants; the Byzantine's Ephesus-II 449 AD and the Roman's Chalcedon 451 AD respectively.

The intricacy and complexity of delving into the origins and genesis of nomadic dogmatism has already intimidated many researchers. One key factor is nomadic recordings are formatted in a desert milieu impregnated by societal chaos, trickery, disorder, violent tribes targeting each other with envy and fiery exchange of most complex poetry to belittle members of the lesser fortune tribes. These tribal characteristics are best described and overseen by the well-articulated Egyptian Deity of the barren desert; the evil Seth. Currently 1400 y later said tribes, randomly-populated countries whose borders were fortuitously sand-penciled by G Bell and TE Lawrence, never abandoned the antiquity of their fossilized domains. Uniquely, their milieu is violence and vengeance without borders. That was ploughed and seeded with the mental riddles of the newly anointed dervish of Mr. Hempher; Muhammad ben Abdel Wahhab. Yet, the recent never-ending wars in Afghanistan, the Gulf area and possibly Iran going nuclear affirmed the wise Russian sober management of the cowboy's yahooing ethnic and religious wars in the Middle East; specifically Syria. That is Western seculars should be willing to conclude the Russian prudence is the most successful protocol to arrest consequences of the major chaotic eruptions in the Middle East. At this crucial point, the International community has to realize the Russian and the Chinese has limited energy to trail and wipe the US establishments' mental vomit wherever the fat-cats decides on a location of economic interest. In this regard, it is our contention Mr. Putin is the right Candidate to Noble Peace not Haj-Obama. At the moment, this dilemma may not be palatable to Westerners who are occupied with a severe economic recession and availing energy to parallel their excessive and meaningless comfort. These economic difficulties persuaded a specifically elected president to posture at a right angle - Yes, We Can Bow - while saluting his Amir, the king of Saudi Arabia; Sadat was absolutely more dignified.

With certainty, the Holocaust of the Egyptian, Mesopotamian, Assyrian, Persian Civilizations, etc., are an excellent yardstick to the causticity of the nomadic dogmatic-political tradition. Considering historical events and societal context, these nomadic attributes can be regarded as the authentic birthplace of Fascism and Nazism. The reader must be armed with necessary patience to realize the TV and media conclusions of Western swift toppling of corruptnomadic regimes would not yield a new energy-order in their favor. The back-of-an-envelope calculation of the so-called swift victory in Iraq and the morass of Afghanistan is expected to yield serious long-term side effects. The ridicule is, the US and Western nations were engaged in Afghanistan and Iraq to limit terrorism within these sandy enclaves. Nonetheless, Jihadists' philosophies were quantitatively transplanted into a new habitation, the US and Europe with the refugees. In few years, firm roots were established and had their representatives, with the crude oil-\$, elected within governments' institutions of the UK and the USA Oval Office. Worse is the expected yield to the US irresponsible setting of Shiite-Sunni duel. The current situation is a mirror image of the swift 1967 Israeli victory which propelled the whirlwind of Wahhabism seeded by Sheikh Sha'arawi to culminate into 9/11 New York, 2004 Beslan school siege Moscow, Sabotage of Beijing 2008 Olympics, Kerdasa 2013 and Raba'a al Adawiya Cairo Egypt 2013, a Canadian soldier was killed at the Parliament Hill 2014 Ottawa, Paris slaughter of a teacher 2020 by a Chechen refugee, etc. Logical. Logical extrapolation dictates: the swift victory in Iraq and in the morass of a teacher 2020 by a Chechen refugee, etc. Logical extrapolation dictates: the so-called swift victory in Iraq and the morass of Afghanistan would yield the nuclear terror of the nomads. To his credit and according to his refined education at the Sorbonne University Paris, the ex-chief of the UN, Dr. B Ghali understood and acted according to the intricate cultural details pertaining to the extremities of the societal inflammations of many spots. He was en-route to contain many of the US-stirred ethnic violence in many nations, e.g., Somalia, Rwanda, and the biased fragmentation of Yugoslavia according to religious affiliations, before any could turn into a global menace. Unfortunately, rather than incubating his wisdom of containing the fields of death in said spots, according to peaceful local agendas, his term was prematurely sacrificed.

In contrast to the unripe and gullible presentation of MGS Hodgson's "The Venture of Islam" and the pornographic portrayal of S. Rushdie's "The Satanic Verses", the current presentation is a scientific analysis to the available wealth of physical data pertaining to the cultural, dogmatic, and the social-economic fabric of the bedouins and its impact of environmental necrosis and mutations of bacterial and viral diseases. That is, the thesis of the present study is not, by all means, a criticism of the cultural thoughts of the nomads or the slightest critique of their treasured faith. The few referenced 
elaborations of the present assay are absolutely: (a) a "reminder in good faith" to the wide array of different interpretations to a given dogmatic event and (b) the brittleness of the cherished three derivatizations of Akhenaten's monotheistic thoughts to rational and scientific interpretations. In general, our thesis to the genesis of dogmatic thoughts, specifically nomadic monotheism, was drafted according to the same very sober logic and rational handling of thoughts according to Ahmed Osman in his "Christianity: An Ancient Egyptian Religion".

We concur; the Egyptians were the premier architects of monotheism as their outlining of the one supreme deity could be traced in human thoughts and response to unexplained phenomena without exception. For example, one of the Islamic staunch portrayals of the bold-headed snake grueling the deceased disbelievers' corpse as of the moment it is laid into graves is basically an Ancient Egyptian mythology. This is not the only Islamic rational which has its roots in Ancient Egyptian or Hellenic mythologies. The Ancient Egyptian bold headed-snake Apep (Data, Figure 11a) is the one who torments the sinful upon death. However, the environmental tailored good nature of the Egyptians allowed a salvation, i.e., human triumph over the snake of darkness, Apep (Data, Figure 11b). The Egyptian water snake "Apep" or Apepi, Apophis Атофıৎ in Greek or a light and truth. Apep was the deification of darkness and chaos (izft or Isfet in Hieroglyphic). The Ancient Egyptian izft or Isfet could be equivalent to the particular current Egyptian Arabic "zift" زَفت indicative of the profound influence of the Ancient Egyptian culture on modern Egyptians. Phonetically, most likely the Coptic Aphōph was further deformed into Arabic أفوف or that is a colloquial manifestation of disgust.

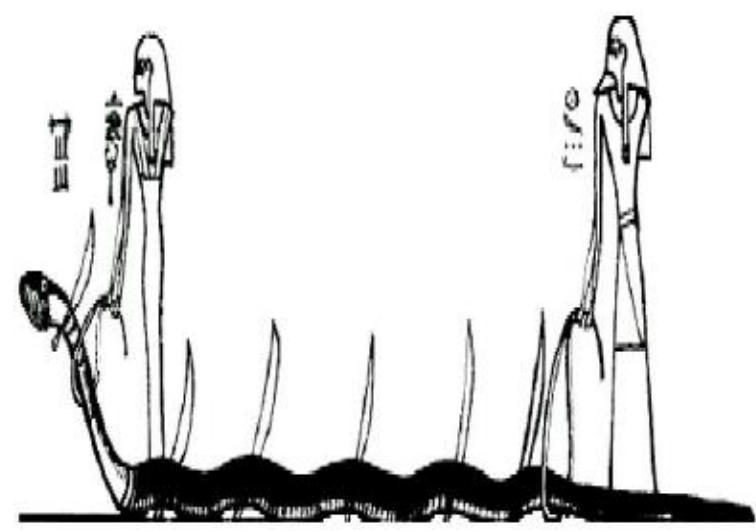

Figure 11a: The Ancient Egyptian Apep.

We are addressing the readers' understanding of our motive of reciting some of the same event under different titles. This measure was stipulated to present each topic as all-embracing critical events which styled the 641-decline of Egypt. As said earlier, the primary concern is to gain a better understanding of the basic fabric of the dogmatic-political culture of the bedouins. That is, to have a true insight into the current vortex of violence that is muddling urgent priorities. Once done, chances of a peaceful conclusion to the current Middle Eastern calamities could be maximized. Thus, the US-desperation to derail the purpose of our humanity, synthesize Isis, Da'aesh, the "Arab Spring" and ferment the Sunni-Shiite $1400 y$-conflicts into regional wars will be shelved. Eventually, chemists will have ample time to address environmental intoxication, disease-control, education, etc.

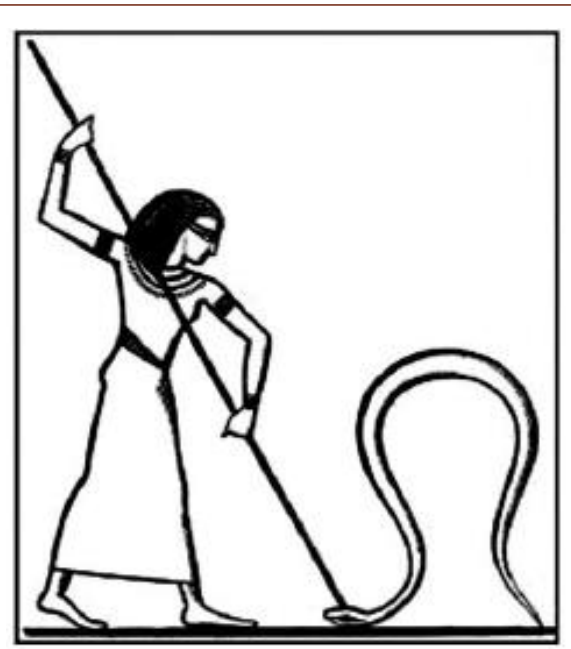

Figure 11b: Human triumph over Apep

According to the recently published statistics pertaining to nomadic sexual aberrations, in Saudi Arabia $60 \%$ of sexual assaults' victims are minors. It is not surprising the least; about one third of these pedophilic incidents are committed by family members. The issue of family violence was further confirmed and discussed at the Jeddah Chamber of Industry and Commerce. Ms. Ina'am Robai, chairperson of the Committee for Protecting Children's Rights at the Armed Forces Hospital, affirmed: child abuse in Saudi Arabia has become a very serious issue. She pointed out (i) $45 \%$ of Saudi children are mistreated during their daily lives, and (ii) $77 \%$ percent of child abusers are parents. If, as decreed, mujahedeen who died in battles while defending the traditions of the Supreme, will enjoy daily mating with unlimited number of virgins and young boys in heaven الغلمان بالجنة المخلدون with unquenched lust Dahman Dahman and always with erect penis, why not on earth too? According to recent sex-crimes in Egypt, in a short span of time, the following heinous incidents were reported:

- In Suhag city Upper Egypt, a mother worried about defamation and gossips, killed her $2 \mathrm{y}$ old daughter to cover up for the grandfather's anal rape of a 2y-old granddaughter. Postmortem inquiry analyses confirmed child's blood stain covering anal rupture,

- $\quad$ The police of the governorate of Qaliobiah found a cadaver of a young worker. His aunt and her husband killed him after his continual attempts to mate with his aunt, 
- Under the effect of narcotics, a jobless worker sexually assaulted his 13y old stepdaughter,

- In the city of Helwan/ Cairo, the police arrested a dumb male sexually assaulting a 10y old female in a mosque's bathroom,

- In the city of Nasr near Cairo, the police arrested two homosexuals aged 13-15y accused of mating with an autistic boy, and

- A woman killed a 9y old baby girl to rob her of a golden earring

With abundant certainty, cause of the above events is HajObama's inoculations of the Middle Eastern states, whose boundaries were drawn by G Bell, with the caustic Wahhabi fundamentalism of the Afghani importees into Syria, Iraq, Libya, Yemen, etc. Accordingly, the obvious effect is the disintegration of the societal values of Egypt which would require an extensive rehabilitation of the Egyptian society. Accordingly, in absolute fairness it is the legal right of the Egyptian government to:

(i) arbitrate, in an international court, their case against the US-political establishment to shoulder the costs of this expensive rehabilitation together with

(ii) repair of physical damages done to Egypt during the time span 2012-16 including costs of re-building damaged churches and renewal of the war devastated environmental, and

(iii) the establishment of an urgent case at the International Crime Court Hague the Netherlands against GW Bush, Haj-Obama and $\mathrm{H}$ Clinton for collaborating with the Nazi-Wahhabis to ruin the Middle East, estrangement of the natives of Syria and Iraq, abuse of refugees and Holocausting crimes against Christian and Yazidis minorities.

Worse, according to the statistics, the overwhelming majority of victims in domestic violence cases are girls (78\%) and boys (21.6\%). The back-of-an-envelope calculation of the statistics showing that 23 percent of Saudi University students were raped at an early age implies that 10 percent of adult Saudi males are homosexuals. A high $62 \%$, of these rape events were never reported mainly because victims were relatives of the male sex-predator.

Together with the negative consequences of militant dogmatism, male impotence is a major threatening factor to the societal integrity of Egypt. Below is a summary of our recent labor.

\section{Deteriorating Male's Fertility}

At this point of time, largely within major city boundaries and in Upper Egypt's villages, cases of male infertility are exponentially on the rise. In particular this is the case of the Egyptian ghettos where the dispossessed are cramped as in sardines' cans. The destitute inhabit filthy milieus that are maximally plagued with pesticides, herbicides and micro-plastics intoxicating basic food ingredients and potable water. Chronic poverty together with scarcity of affordable food products drove them to subsist on rubbish collected food remains and adulterated alternatives, e.g., animal's food, expired donkeys, cats and dogs' meat. They are addicted to swindlers' generic narcotics and Viagra. As current males' infertility is a major threatening issue to the future of the nation and whatever left of its societal cohesiveness, we found it most industrious to tackle this particular issue within these domains.

The management of male infertility in a male dominated society that is floating onto the riddles of dogmatic taboos is an intricate task, indeed. The causative factors of the dilemma are not solely medical but rather the cascaded repercussions of the deteriorating medical care, contraction of a wide spectrum of tropical disease, environmental necrosis and deeply rooted societal factors, e.g., stressful characterization.

Regardless of current economic difficulties, to contain the consequences of Covid-19, a curfew period was imposed and strict personal proximity was imposed during the curfew period. This is to evade as possible the importation of further mutated injuries, viz., the Multi-System Inflammatory Syndrome (incidentally of New York but not of Wuhan). The emotionally balanced political bureau has delegated the issue to the minister of Health (the iron-lady) and scientists. As well, a generous financial relief to 105 million was made feasible. Unfortunately, the populace who once exported the canons and high moralities of the Pharaonic civilization to the vast ends of our universe are happily living in a cocoon of ignorance. To the credit of the iron fist of the minister of health's toil to curb covid-19, the UNHCR acknowledged: within a day 11.5 tons of plastic debris were removed from the River Nile. Foolishly, collective measures of safety were stubbornly negated. In an absurd defiance, the illiterates took it to occupy spaces underneath bridges or gather in private apartments for tea services and sharing water pipes. Alas, both, the insanitary water pipes and scarcely washed teacups are the fertile media for Covid-19 to multiply, but the prevailing logic is let us have fun and "Khaliha alallah"!!!

Semen samples were collected from impoverished individuals found at different locations within large cities and villages of Upper Egypt. Diagnostics were performed according to standard procedures. Results of semen's diagnostics in terms of volume of the ejaculate, the average percentage of Still/Necrotic and morphologically deformed sperm (small, large, double tailed, doubled head) are briefed in Tables A-C below. We opted to examine individuals with the most common biological injuries. That is parties harboring kidney failure on the account of harmful microorganism polluting potable water, HCV-4b, diabetics and diabeticand Schistosoma- patients in contract with HCV-4b relative to disease-free subjects within the age range of each category. According to the range of aliments, to the experts', the data is selfexplanatory. Entries pertaining to the average distribution of still/ necrotic and morphologically deformed sperm and protein values of semen homogenate were reported relative corresponding semen characteristics of same age disease-free volunteers, as possible. Experimental protocols and detailed data together with itemized sperm-DNA fragmentation will be reported shortly. 

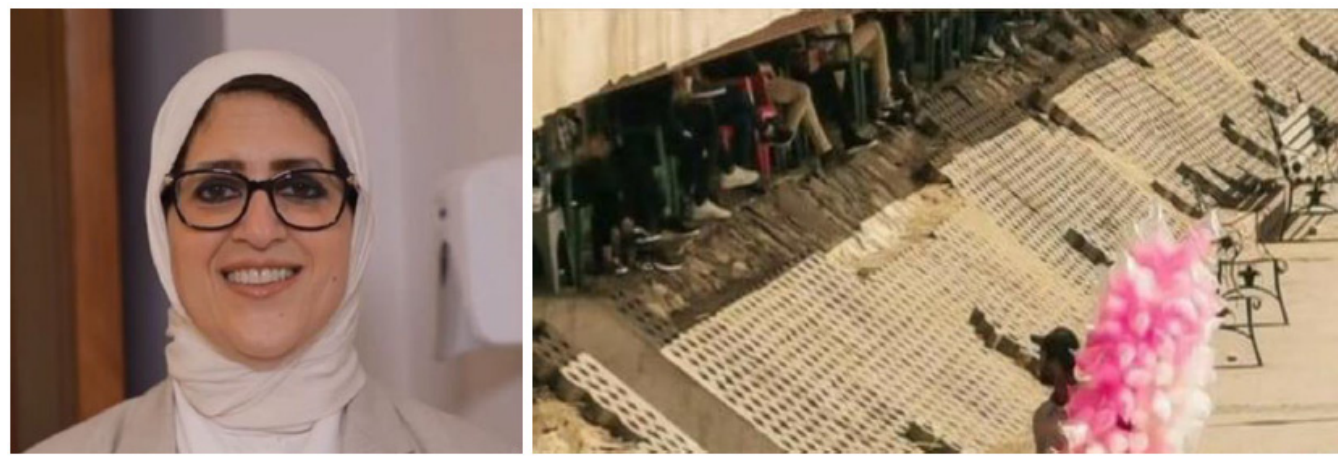

Health measures taken by the well-disciplined Egyptian minister of health are contradicted by the stubborn illiterates.

The most immediate concern is the observed diminutive volume of the semen ejaculates for male's age range, 15 - 60y. We established earlier; serum is in communication with semen fluid proteins. On the account of consumed liver functions, primarily regeneration, the biosynthesis of hepatic intracellular and APR plasma proteins; all assayed semen samples showed 50 - 96\% decrease in total protein of semen's homogenate relative to controls. Regardless of age, diabetics in contract with HCV-4b or liver cirrhotic patients on the account of carrying HCV-4b and Schistosoma scored the lowest in sperm count, normal motility and morphological integrity. Thus, concomitant abortive apoptosis, oxidative stress and morphological damage would precipitate sperm-DNA fragmentation, thus sporadic rates of pregnancy for $>20$ y individuals, if possible, at all.

This reporting is not inclusive as lacks quantitative specificities of hereditary and external factors, e.g., excessive stress, quality of general health, minimal caloric intake of diets, consumption of uncontrolled medications together with addition to low grade alcohols and narcotics. It is then entertained with certainty, under these biological factors of impaired spermatogenesis, rare male 20 - 60y actualization of pregnancies are expected to yield embryos plagued with physical and neurological deformities. Furthermore, by all means, the data is rather limited as diagnosis was performed on a minor scale of the populace, 105 million Egyptians. To manage the phenomenon of male infertility, large scale surveys are deemed essential which are beyond our finances and manpower.

Without advocating the dooms day, truly our mother land is in peril. Most recently, Armant Hospital Luxor reported the birth of a genetically deformed baby, below. This case would require a detailed DNA scrutiny of blood of parents to decide on the carrier of impaired gene. Should DNA inquisition of parents provide healthy results, most likely environmental intoxication would be the factor behind this anomaly. Accordingly, pertinent measures should be drafted to counter possibilities of recurrences (Figure 5) (Tables 1-3).

\section{Conclusion: A Daydream}

And even in our sleep pain that cannot forget falls drop by drop upon the heart, and in our own despair, against our will, comes wisdom to us by the awful grace of God.
Aeschylus (524-456 B.C.)

First, examine our attitude toward peace itself. Too many of us think it is impossible. Too many think it is unreal.

But that is a dangerous, defeatist belief. It leads to the conclusion that war is inevitable, that mankind is doomed, that we are gripped by forces we cannot control.

We need not accept that view. Our problems are manmade. Therefore, they can be solved by man. And man can be as big as he wants.

No problem of human destiny is beyond human beings.

Man's reason and spirit have often solved the seemingly unsolvable and we believe they can do it again, (JFK June 10, 1963)

Together with the River Nile, on the account of an immaculatehealthy environment, at that distant time, the Ancient Egyptians soaked the world with the basic ingredients of ethics and laws binding individuals' uprightness vis-à-vis members of collective community. This would rationalize their feverish and absolute obedience to the omnipotent in terms of poetic statement pertaining to the punishment and rewards in the After-Life. Naturally, these poetic statements were recited on mummified bodies of the deceased. In brief, minds and spirits of the world-wide faithful of the major spectrum of religious trends are captive and addicted to the Ancient Egyptians' early thesis and baked dough of monotheism respectively. Nevertheless, as of 641 they were denied the essence of peaceful survival. In general, Egyptians are passive farmers and slow to react to impending threats and only respond when perils are cancerously grown to shatter their subtle cohesion. For example, regardless of religious affiliations, the Egyptian ladies have instinctively acted against the morbid combination of HajObama-Clinton-Mursi in 2013.

Was it too late? It would have salvaged Egypt of the caustic consequences of the 1952-coup officers, bridled 3 wars, minimized the negative impacts of dogmatic radicalism and halted the dilution of Egypt into the morass of Arabism, if revolted 60y earlier. Although, delving into an inquisitive analysis of the Egyptians' DNA-passivity is of an overwhelming scientific interest, it is not 
the quest of this manuscript. At this point of time, the deafening gears of war, trumpeted by the greed of the very few, are absolutely rallying humans at its maximal pitch and replicating their thoughts according to the aggressive wavelength of crude oil-MIC. To make things worse, ethical values are dwindled as faculties of the besieged Westerners were contained into a well-tailored demoralizing enclave and were purposely soaked with the ethics of Hollywood's glorification of violence. The available option left for the helpless day dreamers of peace is to vent their harmless thoughts in anticipation of seeding the crystals of hope, peace and harmonious living with whatever available of different wavelengths of thoughts rather than digging the trenches in the fields of wars. Thus, dissipating the evil of human's dark corners with the light of the Logos (Figure 6).

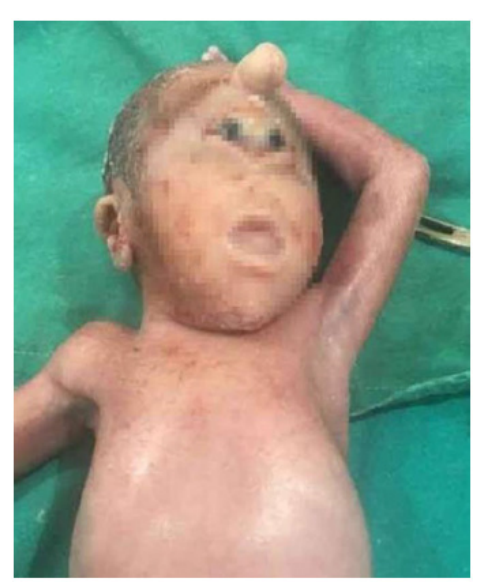

Genetically deformed baby delivered at Armant Hospital Luxor
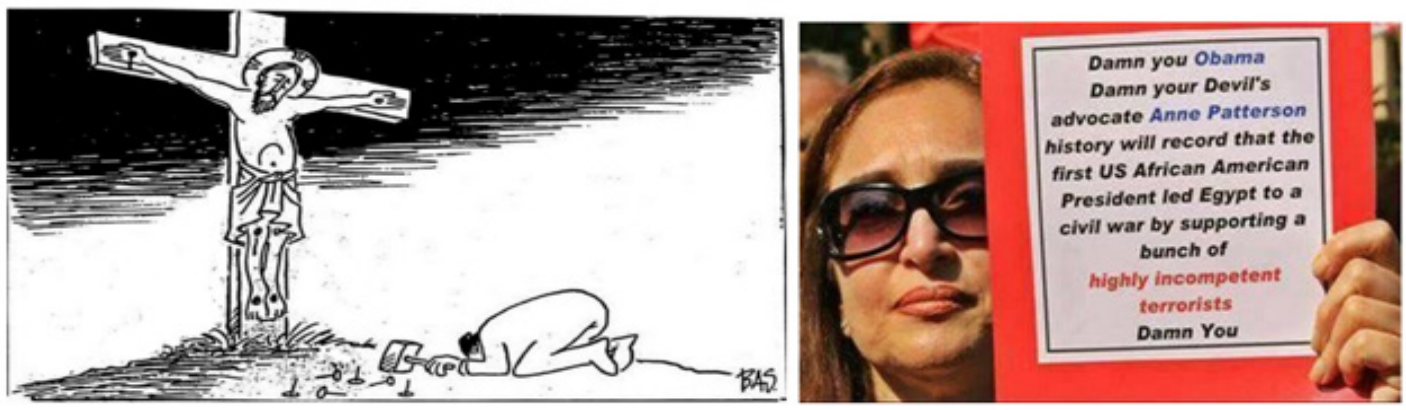

Haj-Obama's Duplicity, the Theater of Democracy, Equality and The Defeat of his "Arab Spring".

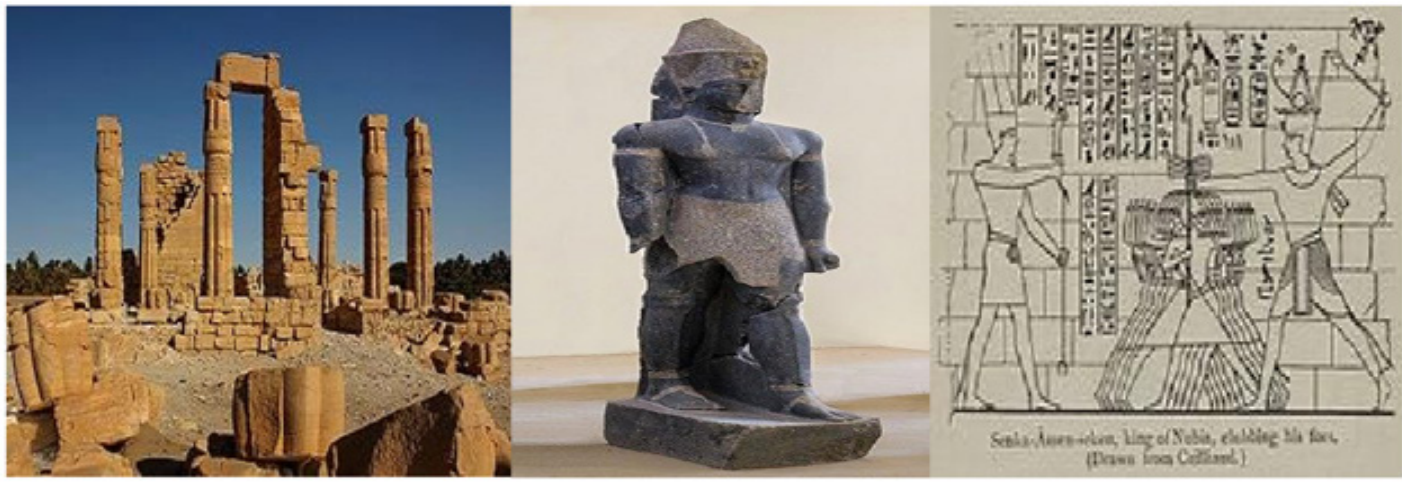

(Portraits 1-3): Extracted Smithsonian Magazine, September 2020
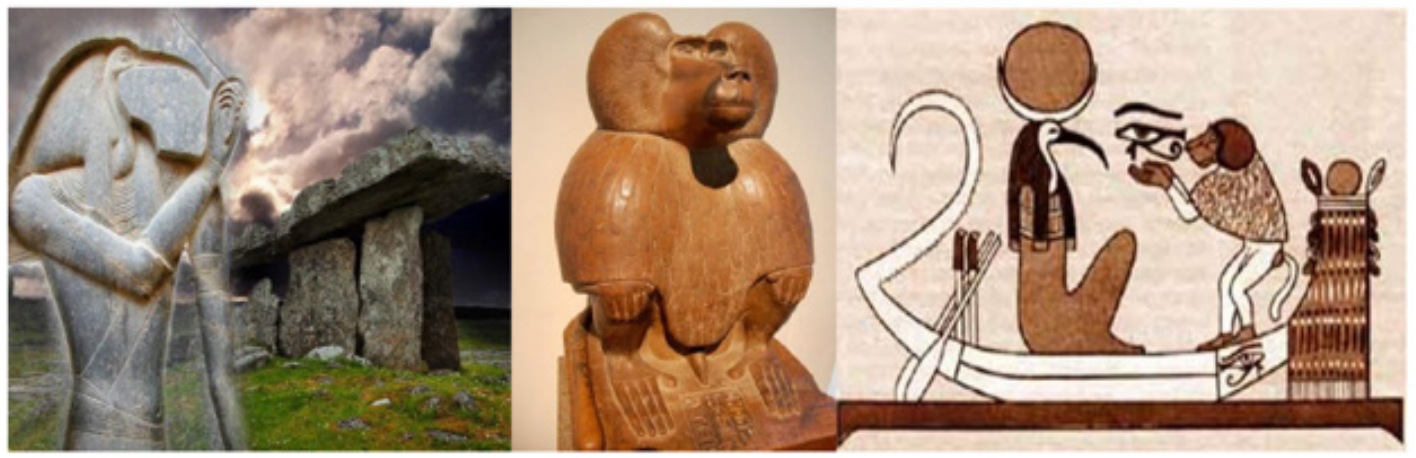

Figure 8: (Portrait 4) Ibis-headed Thoth and baboon primate in boat, remnants of a mummified ape found in Ireland, viz., D Halpin. Thoth's Storm: New Evidence for Ancient Egyptians in Ireland? Ancient Origins 16 January, 2016 - 21:27. 
We concur; the body of our dreams is torn in-between the US principals of the dictatorship of capitalism and the sandy/ arid nomadic terrain. Said terrain is abundant with the causative factors of hatred, wars and environmental necrosis. That is the crude oil. To make things worse, according to religious boundaries (viz., leaked emails of $\mathrm{H}$ Clinton pertaining to the management of external affairs with countries favored with Wahhabism) the ghoulish MIC has taken advantage of the nomadic dry intellectualism - void of rational dialogue - to the maximal ruin of nomadic societal cohesions. Mental labour of peaceful dialectics aimed at a long-term weeding of unnecessary political ambiguities and perils of war was irreversibly wiped and eviscerated when the 1960s leading USscholars were assassinated. The following quotations are indicative of the morbid different styles of the intellectuals versus the political dwarfs: "I dream things that never were and ask why not" and "Ich bin ein Berliner" versus "where is the beef", "Tear down this wall" and the recent chest beating "yes we can". The most plausible approximation is the hypothetical bleak outcome should the events of the Bay of Pigs and the 1962 Cuban Missile Crisis were handled by the macabre combinations; Reagan-Cheney/ the spoke-his son the war president versus JF Kennedy-RF Kennedy? Alas, 1600y past the societal failings of Retro-Akhenatenism, the US-GM never ceased biased marketing of differently manicured Wahhabism. Nonetheless with the same CFS-driven ardent hate and "better than thou" inclinations; Haj-Obama's avalanched the ill-fated Arab Spring. The US-GM blatantly supported the thematic melancholy of the Wahhabis that is the historical burning issue of denying Yeshua's third-day resurrection and His Divinity. Said support was formatted in a ridiculous, provocative and a pale reiteration of the 610-32 dialectique. For example, to flare the sensibilities of the dogmatically hate-pregnant Middle Easterners, the US-GM's provocateurs well camouflaged and diluted beneath the so-called: modernity of intellectual debates, unnecessarily chewed this topic on many occasions at the Cambridge Union Society and the likes. However, historical facts together with the well-established societal coordinates of the Roman civilization at the time denied, the flashy titled, debaters the fruits of forcibly shunting their predetermined conclusions into the throat of the viewers. For example: (i) the shallow argy-bargy "The Real Jesus Christ" and "Who killed Jesus Secrets of the Cross I \&2" [54], (ii) the most recent Netflix's attribution of Yeshua's passivity to homosexuality - in a previous cow-boy argumentations Pharaoh Akhenaten's passivity was rationalized as a homosexuality, (iii) worse are naïve conclusions of the "Sodom and Gomorrah" [54], based on sulphur deposits of specific location in in Jordan. The debater enthusiastically called for an irrefutable evidence of the event "Sodom and Gomorrah"? That is rather superfluous to a humbly educated physical organic chemist. There must be a set of substantial aftereffects to the burning of sulphur deposits. For example; topographical evidence for the natural corrosion and spoilage of the indicated terrain by the $\mathrm{SO}_{2}, \mathrm{SO}_{3}$ and $\mathrm{H}_{2} \mathrm{~S}$ generated by burning the natural deposits of sulphur by the elevated heat associated with the said mythology; "Sodom and Gomorrah". Is it possible: the occupants of the area at that time were burning some quantities of extracted sulphur for domestic or ritual purposes? This particular issue debated at the Timeline series [54] may be scientifically handled according to S Freud postulates of Moses and Monotheism and possible timewise evolution and devolution of Akhenaten's sets of thoughts. It is absolutely advantageous to soberly tackle the genesis and the urgent sociopolitical causative factors behind the catalysis of a de novo Retro-Akhenatenized set of formulation rather than perforating the pillars of earlier theologies drafted at this inquisitive time. Most likely, at this precarious time, said YouTube documentaries [54] are a deliberate and calculated gesture to appease the dogmatic nerve endings of Sheikhdoms rich in oil fields. Nonetheless, it would further hasten the collapse of the already rooting Roman Empire-II with the Maître d'hôtel at its helm. Similar, however fashionable, event of re-improvisation of historical facts is the ridicule of "Who built the Pyramids of Egypt". On the account of incompetence to appreciate Ancient Egyptian's fidelity of individual's thoughts and promptness to infinite toil to maximize its immaculate spiritualism into colossal buildings, say the pyramids, the sphinx, etc., some theorized; aliens must have built it, or at least instructed/ assisted in the building of the pyramids. If correct, it is feasible to assume the Great Wall of China, the 58 meters-statue of a revered general who became a deity of war - late Eastern Han dynasty - and the colossal Greek Temple of Hephaestus were built by aliens, as well.

Similarly, in this context, it is mandatory to entertain the Israelites claim of their share in building the pyramids. For example, Begin suggested Carter's mediation to conclude Camp David's accord to his ancestors' labor while building the pyramids! This habitual claim was critically and archeologically contradicted and refuted by the recent discoveries of the tombs of the Egyptians who immaculately built their pyramids. For example visualize the recent discoveries at Saqqara. We dare hypothesize, considering Freud's thesis of "Moses and Monotheism": the Israelites claim of participating in building the pyramids is an admissible rational. They are Egyptians. The Jews are Akhenaten's adherents who are soaked with the Ancient Egyptians culture. Although opted to flee Egypt to retain fidelity to Akhenaten's Monotheism, they remain the descendants of the Egyptian's race who toiled to build the obelisks, pyramids, the sphinx, etc. They retained the culture of the Ancient Egyptian-village collectivity as later shown by Peter the fisherman establishing the commune in Jerusalem, Paul in Rome, Karl Marx in Europe, Leon Trotsky in Russia and Shehata Haroun and Henry Curiel in Egypt. In this context, it is relevant to hypothesize the Jews were the past dwellers of Avaris, Tel el-Daba'a in the North Eastern region of the Nile's delta. If feasible, it may imply a DNAgenetic relation to the Hyksos of Asia. Hard core scientific approach is deemed essential to rationalize historical hypothesis related to opposing historical stands for the purpose of current peaceful coexistence vis-à-vis entertaining flimsy findings of insignificant pieces of clay (Avaris?).

Apart from establishing collective housing, the Egyptian Jews built special homes in the Jewish alley of old Cairo to accommodate the necessities of the disadvantaged, the elderly and the needy. That is on many occasions; the Jews show the fundamental puritanism of the young Jewish carpenter Yeshua more than the Christians. Rather 
than holding to their sophisticated values of collectivity, current Egyptians were diluted to the inhumane nomadic characteristics, viz., the sex-drive of the attached extracts of crimes. These crimes are the byproduct of Nasser's climax of dictatorship, flamboyantly denoted Arab-Socialism? Worse, in the name of piety and worldly sacrifice for better after life and Celestial's protection, a minority became captive to the loose appraisals of their reigning clergy. For example, with minimal disregard - if there is any - to the threat of facile contraction of Covid-19, the bishop of Assiut led the crowded bare-faced congregation into a massive festivity pertaining to Assumption of St. Mary without masks and social distancing! The Sunday collections of the poor are abused by a leading clergy to build first-class schools and hospitals with luxurious cubicles to accommodate the necessities of the few fat-cats, i.e., a clergy void of the refined ethics of Magda Shehata Haroun. Too bad, apart from 12 living in Alexandria where Philo Judaeus contributed worthy philosophical manuscripts, only 5 beautiful-female candles are left to light the darkness.

Rationally, the Jewish memories were unforgiving to the harsh discriminatory attitude of the Amon's clergy, viz., the gruesome lynching of Hypatia and the Shite cleric Shehata, Alexandria 415 and Giza 2013 respectively. The arid nature of the Sinai desert denied the Israelites, the Egyptian adherent to Aten according to S Freud, the possibilities of retaining their core culture to lead a similar way of life within the sandy habitat. According to the Old Testament, scarcity of sustenance precipitated a revolt against Moses! Except for the harsh handing by the Amon clergy, in time, the Israelites lost, and religiously estranged themselves of. their genetic memories to the Egyptians. Furthermore, Egyptian Pyramids are found in Greece and all over the world there are remains of ancient Pyramids dating to to antiquity, including those found in the Aegean and the Greek mainland and Mexico. Researchers have discovered pyramids near the village of Sougia in southern Crete, a pyramid on the island of Keros, another in the Greek mainland in Argos - known as the pyramid of Hellinikon and a Sphinx in China. In summary, the Egyptians and the Greeks were in communication prior to the Alexander 332 BC conquest of Rakodah (Rhakotis). Obviously these findings negate the ridicule of the aliens' visitation to Egypt to allure building these colossal monuments.

Amazingly to the same area currently embracing Israel, Lebanon, Syria, Yemen and Iraq, the Egyptian exported a de-novo blend of their devotion to deities, i.e., the Druze conceptualization: Kitab al-Hikma. A critical scrutiny of this latest exportation is indicative of a degenerative propensity to hatch novel philosophies as Ancient Egyptian fidelity was profoundly diluted with nomadic tenets. Kitab al-Hikma thoughts are at best an amalgamation of Melkite Orthodoxy and Fatimid's Islam. Most likely, this assumption is pertinent as the founder of the Druze, the 6th Fatimid ruler of Egypt and 16th Ismaili imam, 996-1021, al-Ḥākim bi-Amr Allāh's mother, al-Sayyida al-Aziziyya, was claimed a Melkite Orthodox. That is pivotal in understanding his referral to himself as "A'akal Al Kul", i.e., the Logos of All. Hakim displayed a meditative tendency to asceticism and withdrawal at the Mokattam hills outside Cairo which prompted his demise. Hakim left for one of his nights' withdrawals, and never returned. A search found only his donkey and bloodstained clothing. Historians claim his demise was engineered by his half-sister Sitt al-Mulk.

As of the macabre MIC-food-pharmaceuticals axis soared to hybridize with the petrodollars and the murder of the two intellectuals, JF and RF Kennedy; surreal entities dominated the political spectrum of the US-Oval Office, e.g., the Watergate, Bonzo, the war, the Haj and the I-in-C presidents. Most likely, this axis assisted the synthesis of a Noble Prize clique with a specific agenda. In brief, it is an immature and a ripe US-combination à la the UKmodel of Mr. Hempher-Abdullah bin Abd al-Wahbab. The clique was a unique collection of the most radical Middle Easterners Jihadists and US leaders, both are conceptually bent to the service of the MIC. It embraced: (i) the axis of Bible waving-Carter and the Wahhabis assassins Sadat and Arafat to deliver the peace dwarf of Kamp David, and (ii) Haj-Obama and H Clinton's engineering the Arab Spring to place their Pinocchio Mursi at the helm. Mursi in collaboration with Erdogan, radical Palestinians and the ignoramus Yemenite, Tawakkol Karman, the Arab Spring was intended to enlist the nomads regardless of nationalistic belonging in the kalifates of Da'aesh and Isis. Interestingly, post-2013, all supported the disgraced Führer Mursi and the most notorious Jihadi secessionist of Raba'a al Adawiya. Haj-Obama driven by a camouflaged dogmatic hatred (Indonesian Madrassa) did sponsor a former prisoner of war, senator J McCain, to visit the imprisoned Wahhabis including Führer-Mursi. Carter's protégé, Sadat the assassin, has his own agenda as cultured the impregnation of the Western/ Asian terrain with the fundamentals of the imams of Da'esh and Isis to pus Western and international Jihadists. One of the very many was Sadat's spiritual mate, the grand Imam Sheikh M Abdel Halim who soaked the Middle East with his hatred to individuals with different thoughts, according to his fattwa: they should be persecuted and evaded as they are like contagious disease"! Eventually, Dr. F Foda, K M Saeed and M Daniel were assassinated. The nightmare is; the very same individuals adorned with the Noble prize for possible peace are not sparing a nation of their jihadi hatred and vomits of dogmatic wars! The fundamental question is: How can an ever lasting peace between Israel and nomadic nations perforates centuries of thick layers of hatred? It is our expectation: regardless of the crust of diplomatic smiles and abolishing long due loans; the most recent Hollywood's trumpeted sales of Israeli-nomadic peace, expect for Morocco, would not last. It is rather a feasible extrapolation; should the Saudi substantiated their written 1940s promise (Figure 9a), the Middle Eastern populace would have escaped the humiliating defeats and human tragedies of 1948, 1956 and 1967. Alas it took 1973 to replace this barely legible document with Carter's mongoloid Camp David's peace accord.

Two goat heads will not differ on the devastating ruin of human morals; the loss of societal cohesion and the ensued environmental ruin post WWII. The irrevocable lesion committed against morality as lives of no less than 6 million Jews were harvested is a permanent stain of current daily life. All supplications and burning candles will fail to erase it. Equally preposterous, is the atom bombing of Hiroshima and Nagasaki which immediately wiped their targets and 
within 2-4 months, the aftereffects killed between 90,000-146,000 individuals in Hiroshima and 40000-80000 in Nagasaki. The absolute mockery the Allied generals and politicians in a synthetic fever of fidelity and pale expressions of innocence, all denounced the Nazi crimes against the Jews. The vast and most efficient British spy rings, shuttling between England, France and Germany had an obvious command over the minute details of the Nazi maneuvering, make this plastic innocence and the 1945 Nuremberg trials one of the most unpalatable event marketed by the allies. With certainty, it could be hypothesized with the rapidly advancing technologies of mechanizations, the fat cats of different denominations, i.e., the allies and the Nazis, differed on sharing the available international natural resources. Thus, rushed into WWII to settle issues. It took longer than anticipated. That is with the anointment of the waring lords on either side, the slaughter of more than 6 million Jews were a casualty of the necessity. With the collapsing ethics of the Westerners, the slaughter of six million Jews was a minor event which at the end of the duel would allow the victor to market the 20 century policies of governance; Nazism, Democratic liberalism versus Communism. Not only the Allies knew the minute details of the Nazi massacre of the Jews but were from the very beginning the collaborators who refused to admit a Jewish escapee of children into safe domains over flimsy issues. Consider, Roncalli, the patriarch of Venice, while in Turkey with his limited resources knew about it to save the lives of many Jewish children. In this context, rightly so without media trumpeting, Sissi took his pound of flesh for the slaughter of 25 Egyptians in Libya. Moreover, scrutiny of historical data reveals mind staggering topics. For example, many parties with vastly different political inclinations and agendas including the democratic-free USA did collaborate with the Nazis:

A. The US leading general of WWII who publicized the soul wrenching photography of the Jewish victims of Nazi camps did not hesitate, when elected president, to pose at his office with the British synthesis; the Egyptian leaders of $\boldsymbol{M B}$ (Data, Figure 5b) That is not surprising. From the very beginning, the core of the Western establishment was in bed with the Nazis! At the end of the WWII, documents pointed to a Nazi general Gehlen as a close CIA collaborator. His "Gehlen Organization" became the backbone of West Germany's Foreign Intelligence Organization, the BND.

B. As much for the sake of military bases close to the borders of the USSR, the US political establishment turned deaf ears to the Turkish-engineered 1914-23 genocides of the Armenians, Greeks and Copts and the current Erogan's holocausting the Armenians in Azerbaijan,

C. Israel was able to conclude its 6-day war against Egypt according to information provided to Mossad by an intelligence network of former Nazis, and

D. Omar Amin (born Johann Jakob von Leers) an Alter Kämpfer, an honorary Sturmbannführer in the Waffen SS in Nazi Germany, a pillar of the ideologues of the Third Reich and a professor known for his anti-Jewish polemics took the name Omar Amin and served in the Egyptian Information Department and an advisor to Nasser.
While striving to flee death running like a caged rat jammed into a boundless web, of wooden-supported trenches of the First World War, saturated with overpowering odour of putrefying human remains and echoes of shrieking souls, W Owen whimsically documented the dreadfulness and the unnecessary waste of life and blood in the few illuminating lines below:

So, Abram rose, and clave the wood, and went, And took the fire with him, and a knife.

And as they sojourned both of them together, Isaac the firstborn spake and said, My Father, Behold the preparations, fire and iron,

But where the lamb for this burnt-offering?

Then Abram bound the youth with belts and straps, and builded parapets and trenches there,

And stretched forth the knife to slay his son. When lo! an angel called him out of heaven, Saying, Lay not thy hand upon the lad, Neither do anything to him. Behold,

A ram, caught in a thicket by its horns; Offer the Ram of Pride instead of him.

\section{But the old man would not so, but slew his son, And half the} seed of Europe, one by one.

At this particular point of human wretchedness and irrationality, it is soul mending to assume Abram at his second rising will hail the precious blood of Menas Daniel and Khaled Saeed. Let us delve into a different stream of thoughts vis-à-vis the conformity of Abram, specifically it is contemplated according to our thesis above: one of its prime derivative is the kibbutzim as envisioned by the fisherman Peter and later Paul and Trotsky: Yield what you have to the community and Take only what you need. The reality is: the philosophy of Peter, Paul, Marx and Trotsky's pertaining to the collectiveness of the kibbutzim is ultimately the most appropriate substitute to the greed-worn out ultra-capitalism of the Western civilization.

According to traditions, Abram has slain the lamb in lieu of the beloved Isaac. Could it be, in vain? Centuries later, the Wahhabi cousins, with the generous aid of Western political establishments, have nested into many world-wide dark webs, which are tailored à la Retro-Akhenatenism. The cousins are already lynching many Isaacs as accused of deviance to the postulates of the correct path. Albeit, TV marketed as Haj-Obama's Arab Spring's dogmatic puritans / the Syrian "Rebels", they in a tsunamis-like irrational hate, ravaged the very many of the Middle Eastern minorities and preyed on females. To the dismay of Abram, the "Arab Spring" cohorts explicitly articulated sacred and unyielding intent of holocausting the seed of Abram and those whoever fail to bow to their specific brand of Retro-Akhenatenism. However, in $2 \mathrm{~K}+12$ the great father smiled as the Egyptian ladies proudly crippled beyond any repair Haj-Obama's scheme of "Arab Spring".

The unadorned reality is; we are politically infertile, that is our stream of thoughts is basically briefed in a daydream whose genesis is the Middles Eastern dilemma emanating from the predominant culture of hate and mythological delusions. In this context, we dare claim; the theistic monopoly of Pharaoh Akhenaten was the 
first baptism of the dictatorship of the "narcissistic monotheism" which coerced the purge of other deities. Although, this particular question is not in harmony with the portrayal of our dream, we find it essential to inquire: was Pharaoh Akhenaten a narcissist who transcended his chauvinism into an adoring monotheism of himself? Thus, with the advent of Monotheism, the freedom of the Ancient Egyptians to elect the deity most favorable to their whims and offerings to corresponding prelates were curbed and ran dry respectively. Not surprisingly, Aton's Monotheism expired with the death (assassination?) of Pharaoh Akhenaten. This event was a landmark of the first blood-stained religious revolt to reinstate the polytheism of Amon and other deities. At this point of discussion, it is harmless to assume; subject to the culture of a given congregation, the monotheistic thought of Aton occupied the soul and brains of humans but under different terminologies according to the necessities of given circumstance of corresponding environment and communal intellectuality of different milieus.

We are Egyptians, i.e., absolutely proud of the refined Pharaonic heritage of our motherland and under no circumstance will deny the color of our skin, the 7000y civilized Egypt. Nevertheless, regardless of the outcome, we are bound to yield to conclusions of a rational inquiry into a set of events provided done unbiasedly and in good faith. Here we are suggesting few fundamental landmarks, of the very many, which characterized the psyche of the populace of the Middle East:

A. Most likely, the dictatorial themes of monotheistic absolutism have masked the mental vision of the early Christians to realize: at that distant time, the crucifixion of the young rabbi; Yeshua was an inevitable and a justifiable finale to the Jewish dilemmas at that distant time. Nonetheless, it is the absolute right of His followers to believe in Yeshua's Divinity as the Logos/ the aw and that His Tribulation and Crucifixion absolved human's sins. At the might of the Roman imperial dominance, His passion to reconcile spirituality to the necessity of the time and His immense love bestowed unto the societal rejects - handicapped, sinners and tax collectors - may have epitomized a threat to the religious and political integrities of the Sanhedrin and the Rome respectively? Reading the Bible differently, on two occasions, serenely the Rabbinic establishment endeavored to communicate with Yeshua. They attempted to deliberate and exchange thoughts with Him on two occasions. Two particular issues pertaining to the lucidness of their religious fabric were tackled. However, according to present day measures of political correctness, the approach to Yeshua was confrontational rather than a rational quest to expound on common values. The dictator of monotheism! Openly, they tried to contradict His passivity on two prime and urgent issues. First, (i) they tackled the authenticity of His preaching vis-à-vis a sinner caught in "the act", Mary Magdalen, and challenged Him to stone her (ii) on a second occasion endeavored to trap Him; to whom should we pay taxes: Elohim or Caesar? This was primarily to portray Yeshua as a mutineer to the establishment of the faithful, and (iii) He was accused of violating the Sabbath while healing the handicapped of their misery. In all occasions, He deflected their motives; (i) he who is without sin, let him cast the first stone and (ii) give to Caesar what is to Caesar and the Lord what is to the Lord. At this very point of time, His threat to the intertwined civil and religious establishments became apparent. Shall we try to mentally digest the urgent motives behind said melodramatic, however clumsy questioning of Yeshua (i)-(iii)? The reality is; as it is in downtown NY, Chicago or other large cities, at that distant time for one reason or another, hardships of life impelled some Jewish females to liaise and/ or engage with the Romans and in absolute fairness, His response disavowed the intended religious dervishism to deliberate on the necessities of the daily dilemmas of the dispossessed. On Friday, the disadvantaged received His entry into Jerusalem waving palms chanting the "Hosanna". It was too late; elders of the Sanhedrin had to organize for His arrest as realized all means of communications with the Young Idealistic Rabbi were impenetrable and Jerusalem was on the verge of a revolution. Rightly so, for the sake of self-preservation and hegemony over the masses (which is the prime concern of any religious firm regardless its orientation), it was deemed for the Jewish elders to collaborate with Herod Antipas to have Pontius Pilate to crucify Yeshua over flimsy doctrinal issues of the least interest to a heathen Roman, Why not? Worse is the irrationality of the Jewish elders to entertain the gravity of the Sabbath breaking on the account of healing the handicapped or feeding the dispossessed concomitantly turning a blind eye to the womanizing of the Herod Antipas's effervescently yielding to his sex hormones was the tragic decapitation of John the Baptist.

Void of any scientific rational, it is our contention; various dogmatic thoughts are available to individuals to adopt according to his/ her cultural stand. Release of scientific inquiries into a given event is rather risky as it may yield opposing alternatives. For example, the 1646 BC plagues and the parting of the red sea could be the expected products of the Santorini volcanic eruption. There are overwhelming historical and scientific rationale to that volcanic eruption which has attracted hordes of locusts and induced erratic animal activity; largely due to the alteration of air pressure and weather conditions. Considering the many remnants of Ancient Egyptian found on site, it is very likely the Egyptians communicated with the Aegean populace. Thus, Africa is a fundamental building block of ancient Greece and the Western civilization; the Egyptians are in all of us:

In the Sudan; Ruins at the Temple of Soleb, were dedicated to the Egyptian sun god Amun-RA. The temple's patron pharaohs included Tutankhamen, who had his name inscribed on a red granite lion, below portraits 1-3,

In Ireland, portrait 4,

Initiating the Chinese dynasties and culture: A geochemist Prof. S Weidong lectured on several ancient Chinese classics at the University of Science and Technology in Hefei. He quoted the historian S Qian's regarding the topography of the Xia Empire dating from 2070 to 1600 BC. That is China's founding dynasty. S Weidong hypothesized the founders of Chinese civilization were not in any sense Chinese but actually migrants from Egypt, the Sphinx in China portraits 5. Prof. Sun further elaborated On China's Bronze Age technology; Sun argues it has gained an access by sea to 
China rather than the traditionally assumed prehistoric Silk Road. According to Sun, its bearers were the Hyksos, the Western Asian people who ruled parts of northern Egypt as foreigners between the $17^{\text {th }}$ and $16^{\text {th }}$ centuries $\mathrm{BC}$, until their eventual expulsion. He notes that the Hyksos possessed at an earlier date almost all the same remarkable technology - bronze metallurgy, chariots, literacy, domesticated plants and animals - that archaeologists discovered at the ancient city of Yin, the capital of China's second dynasty, the Shang, between 1300 and 1046 B.C. Since the Hyksos are known to have developed ships for war and trade that enabled them to sail the Red and Mediterranean seas, Sun speculates that a small population escaped their collapsing dynasty using seafaring technology that eventually brought them and their Bronze Age culture to the coast of China. A further support to Prof. Sun's argumentation is the sphinx was found with eight other carvings, including a warrior, lion, camel and horse in Guyuan City in the Ningxia Hui Autonomous Region. The sphinx stands 36 centimeters (14.2 inches) high (Figures 7,8).

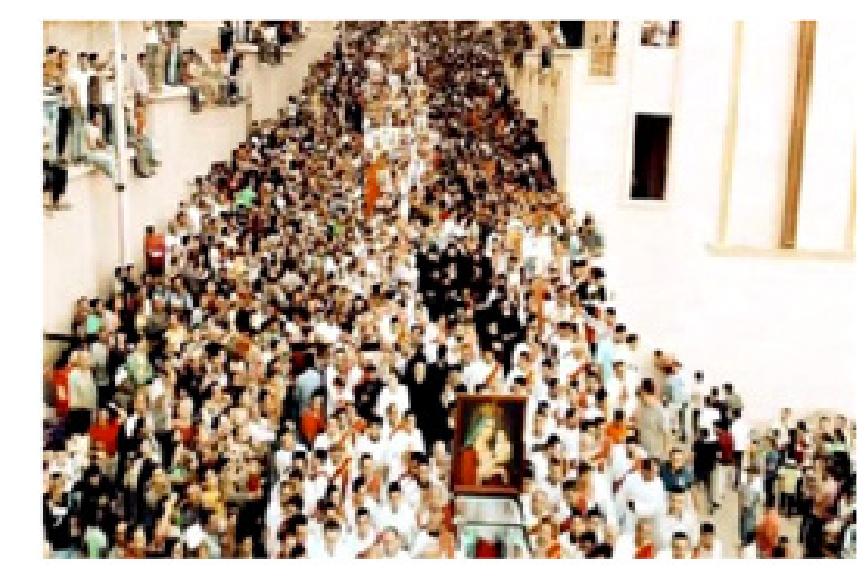

With the least regard to precautions to minimize the spread of Covid-19, Copts celebrated one of the occastons on 2020
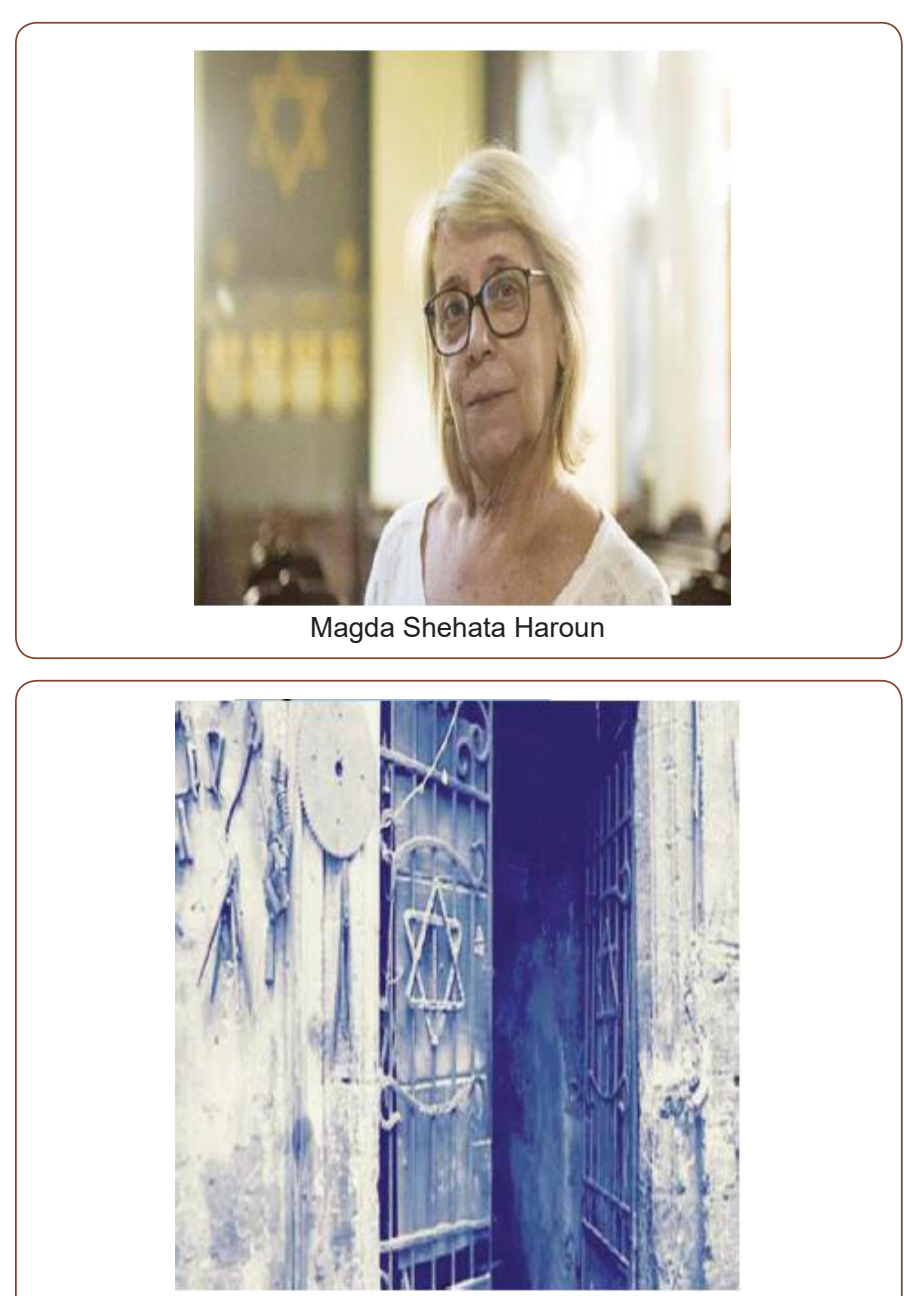

Jewish quarter in old Cairo

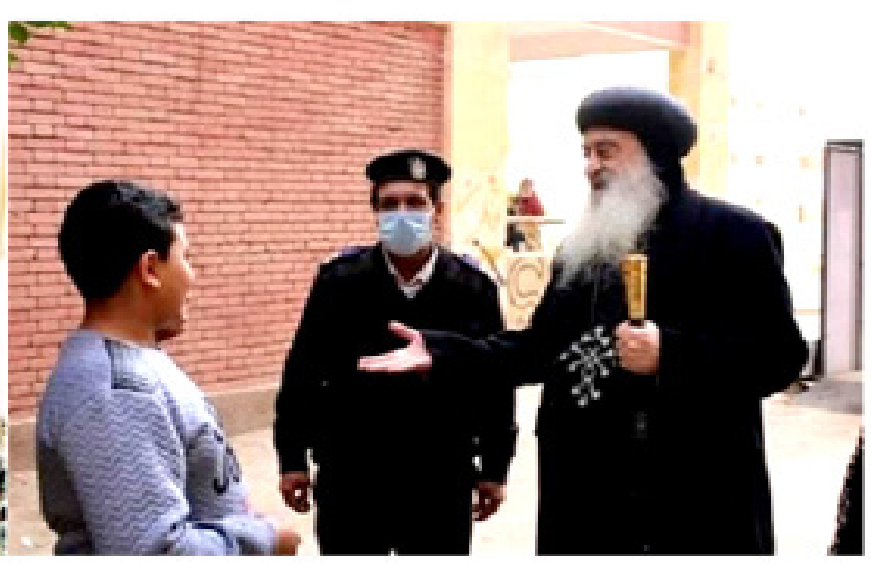

With the least regard to Covid-19's governments' regulations, a Coptic Bishop appeared in public without a mask

Ecclesiastically, the situation exponentially deteriorated as the Middle Eastern theologians of Alexandria, Antioch and Jerusalem, impregnated with stimulating ancient cultures, did not cease philosophical wrestling with the Greek counterparts of Constantinople (Ephesus-I and II) and Rome (Chalcedon). Undoubtedly the context of these debates, which was primarily focused on the Nature of Yeshua and events of Salvation at the cross, stirred and fueled anti-Jewish sentiments within the laities.

B. For the second time and for the sake of self-preservation, the Jewish elders had to politically deal with the concluding flames of hatred of these councils. The strength of the Jewish state at the time was proportionally disfavored to the might of the Byzantine Empire and its satellites. Primarily, they were deprived of the mediation of Pontius Pilate-Herod Antipas' axis as the Empire adopted the teaching of Yeshua. Thus, to contain the overblown antiJewish sentiments and to protect their community, at that distant time, disastrously they opted to engage behind the scene by proxy. Thus, synthesized a third monotheism to negate and consume the source of conflict from within, i.e., the crucifixion and resurrection of Yeshua. Logically, the most plausible location for this call of this third monotheism should be an inaccessible congregation to the Byzantine Empire law and order and fertile with excommunicated "heretics" tainted monks and bishops, e.g., the Nestorians of Syria and Iraq; the Chaldeans. It could be hypothesized with great certainty, the patriotic sentiments and bias to specificities of ancient cultures did plague the religious orientation of the early Christian councils and flared the Middle Eastern populace into schism. Thus, with plausible certainty, on a scale of $100 \%$ Greek Orthodoxy, 
Egyptian, Syrian, Ethiopian, Armenian, etc., should mark 98\%.

The most conspicuous example is the Syrian city Qadesh that is Q-D-S, meaning "Holy" Q-D-S قدس ?. The city Qadesh (Q- D-S) al-Quds القدس was culturally a Hittite which became a threat to the uniqueness of the Egyptians. This cultural threat prompted the Pharaohs of the 18th Dynasty of Egypt, e.g., Thutmose III, Amenophis II, and Haremehab, to quench it in favor of the Egyptian deities. That was an early bias of the state power to a given clerical trend. This trend of rivalries of divinities lasted to extrapolate into the Christian era. Nestorius the Patriarch of Constantinople (of a Syrian Origin was naturally tinted by the thesis of Gilgamesh's Dualism) was excommunicated by Patriarch Cyril the Egyptian (soaked with 5000 years of Usire's Indivisibility, the "Oбıрıs in Greek). This animosity surfaced in 1961 when a Syrian army coup terminated Nasser's dominance of the United Arab Republic.

The southern belly of the Byzantine Empire was a composite of different nations with contradicting cultures. Emperor Constantine failed miserably to safe-guard the political integrity of his nascent Empire. At Ephesus-I, prelates failed to contain the genetically inherited burning desire of theological wrangling to ascertain supremacy of a given set of thoughts as the Absolute Orthodoxy. Adherents to opposing theologies did migrate to shield their distinct believes. Thus, the dilemma of Jerusalem was thawed. Phonetically, it is very probable the Syrian city Qadesh is Q-D-S? That is an etymological name which does not necessarily imply the particular location of al-Quds is the current geographical location of Jerusalem? The ridicule is; not only are the nomads struggling for a city with unknown identity and location but for the 2000 years past, some tribes carried a hate DNA engraved crime against minorities. The major yield of this phonetical misunderstanding was 4 wars, evolution of second-generation bacterial and viral diseases, dogmatic aberrations and environmental necrosis? The prominent absurdity is although it is the yearly money-making season; on Friday Pascha, the Jews of the city have to maintain neutrality while a minority and visitors are supplicating to Yeshua's compassion and His Tribulations on the cross concomitantly the majority, on weekly Friday prayers, are entreating the conversion of the Jews to apes and pigs in the afterlife [55]! Thus, it is feasible to visualize; the Jews of the Holly City Jerusalem are more likely to develop variant depressions and psychological characteristics vis$\grave{a}$-vis the Jews of other cities within Israel? The urgent question is: is money making of yearly pilgrims' season worth all sides inflecting perpetual stress on the Israelis of Jerusalem? The optimal is peace agreements à la the elevated ethics of General Sissi and Moshe Sharett, viz., unpublished accounts of a prominent Quaker Wesley Elmore Jackson.

On the long run, the inflexibility and imprudent characterization and labeling of the Jews, on the account of arbitrating The Decent young rabbi Yeshua, led to (a) the Papal-disastrous and immoral, however mute, support of the Nazis' slaughter of six million Jews, and (b) the later day tailoring of a momentarily supporting monotheism turned not only to curse the Jews as pigs and promised their mutation to apes in the afterlife but also carried out the mass slaughter of the Qurayzans and the genocide of other arab-rich Jewish tribes.

\section{Visualize If the:}

- $\quad$ library of Alexandria with its valuable contents embracing the documentation of $7000 \mathrm{y}$ sophisticated culture and scientific advancement survived the 641 nomadic invasions of Egypt,

- Jewish population remained safe, toiled in peace in their ancient land, i.e., wishfully and miraculously erasing the evil of the slaughter of the Qurayzans and the 1939-1945 genocide from human calendar, i.e., placing every shekel and thoughts in scientific endeavors, agricultural research and elevating the general media with scholarly art, and

- If treasures and resources of crude oil are owned by the Jews, unquestionably according to the collective ethics of the Ancient Egyptian village and the kibbutzim's utopia of Yeshua, Paul, Peter, Karl Marx and Trotsky the world would be a much better residence to all enjoying the beauty of hard work and equally sharing the extract of nature's wealth. Thus:

- $\quad$ the dispossessed will have a guaranteed quality life; for example, gathered and rehabilitated in appropriate kibbutzim. This is to avail a range of opportune employments tenable to their rusty skills. This nirvana would help their claim of lost societal respect and individuality and erase the societal insult denoted "the homeless" from our midst, and

- children of the dispossessed, are socially guaranteed the appropriate policies confirming their heavenly given rights of free medication to all, education to the youngsters and non will agonizingly sleep on an empty stomach. This nirvana would allow them of their given rights to flourish and add plenty of positive toils to the societal network.

\section{The finale of this pipedream}

The first: The US-creation of Sunni Da'aesh was greatly facilitated as a response to the historical memorandum of atrocities and aggressive deeds of the Sunni-Shiite duel of Iraq, Lebanon, Iran. This is indicative of the superb memorization of the historical and blood-stained events which characterized the 1600 years SunniShiite conflicts by various nomadic tribes. Equally correct: how could the dogmatic Ku Klux Klan ask the Jews and the Serbs to forget their sacred cities, Jerusalem and Kosovo respectively, the Armenians to forget their victims massacred by the Ottomans, the Greeks to forget Constantinople and the Copts to forget the library of Alexandria, Deir es-Sultan, their language, identity and their victims exterminated by the 641 nomads? Deir es-Sultan is a Coptic Church property; accordingly, it is the property of the state of Egypt.

The second: considering $20 \%$ of the 850 individuals awarded the Nobel Prizes are Jews; how many Jews could have been the recipients of this most prestigious honour if our planet was spared the slaughter of the Qurayzans and the genocide of 1939-1945? 
Jews in general comprise less than $0.2 \%$ of the world's population. Remarkably, Jews have won a total of $41 \%$ of all the Nobel Prizes in economics, $28 \%$ of medicine, $26 \%$ of Physics, $19 \%$ of Chemistry, $13 \%$ of Literature and $9 \%$ of all peace awards.

The third: The axis Clinton-Obama conveyed the blessing to the Egyptian army generals, the police officers and the Muslim Brotherhood to halt supporting the rioting Copts. The culmination of these biased strategies was the Maspero massacred Copts. Thus with great certainty, it could be entertained: (a) how many millions of Jews were massacred by the Nazi SS-officers with the full knowledge of the US-PB, and (b) with the blessing of the axis Clinton-Obama-Albright together with the infield protection of the US army / imported Taliban; how many Serbian Orthodox were massacred by the Nazi Kosovans? This scheme necessitated quenching the arbitration and the removal of B Ghali from his UN post! As a cover-up, the Hollywood's produced the fabricated news of "killing the Kosovans"? In a typical Canadian obligation to justice and puritan morality, both Canadian Major-General Lewis MacKenzie and Canadian ambassador, James Byron Bissett contradicted the Hollywood fabricated US accounts of the war in Yugoslavia? and

The fourth: three Middle Eastern religious texts are supposedly readily available to freely adopt according to individualistic societal status, awareness of cultural standing and nationalistic sentiments. Interestingly, the three set of thoughts agreed on a given event. That is the parting of the red sea post inflecting major plagues on the Egyptians. However sober scientific inquiry shrouds this very event in a multitude of circumspections. It is our intention to discuss said event without any bias or preconceived thoughts. If two individuals, e.g., Sadat and Begin with radically different cultures were able, through the mediation of a Taliban arm-dealer Carter, to labour the Camp-David dwarf, chemists with their aptitude of scientific rationalism should be able conclude mechanisms of parting the red sea. To start with, it is a scientific anathema to forcibly coil observations in a tin of predetermined thoughts to conclude in favor to preconceived emotions, e.g., The Exodus Pattern of Evidence. A dynastic shift of hundreds of years of Ancient Egyptian kingdoms ((A) below) was taken to parallel historical events to the exodus. A plausible rational to account for the red sea parting and the plagues would be the immense cataclysmic consequences of the 1500 BC Santorini volcanic eruption which was almost equal to hundreds of the Hiroshima atom bomb. A detailed accounting of this event as per the Old Testament is recorded on Pharaoh Ahmosa I Stella ((B) below). Interestingly, Ahmosa I was the Pharaoh who rid Egypt of the Hyksos to become the current nomads domesticating the oilrich sands of Arabia. These sober considerations would not allow for flimsy assumptions based on assigning the finding a different garment ( $(\mathrm{C})$ below) among the heavily abundant treasures of the Ancient Egyptians as a variant dress to a different tribe lived in Egypt 1500 BC. This unbiased conclusion may help cementing peace among all of residents of the Middle East regardless color or religious preferences.

Obviously, the question is: How many James Rothman and Randy Schekman, Arieh Warshel, Michael Levitt and Martin Karplus,
François Englert, Walter Kohn, Otto Stern, Albert Einstein, Hans Krebs and Martin Karplus, Rita Levi-Montalcini, Herbert Hauptman, Robert Furchgott, Arthur Kornberg, W.M. Haffkine (saved millions in India) and Je-rome Karle, the world lost on the account of exterminating 6 million Jews? And (b) with the blessing of the axis Clinton-Obama-Albright together with the infield protection of the US army how many Serbs were sacrificed to appease the oil-rich sheikhdoms?

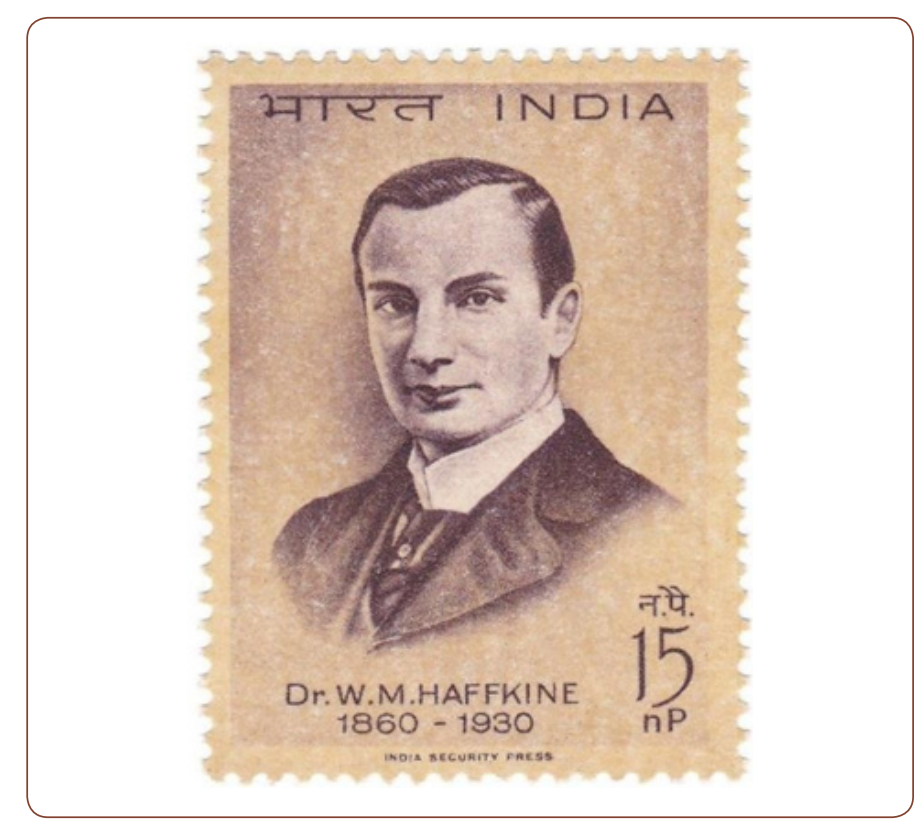

We are finalizing our daydream lamenting the lost humanity Unable to shed tears as eyelids turned dry and cracked for witnessing the horror of the Final Solutions masterminded by the nomads and Nazis to deracinate the Copts, Armenians, Greeks, Jews and Serbs. Wars and threats of wars are an absolute evil, waste of human faculties and resources and shatter integrities of both, the victors as much as the defeated. It would be the renaissance of Martin Luther's Puritanism should the very few fat-cats humbly wash the feet of the millions of the dispossessed for the long years of abuse. It has been a long march of 1600 years alienation, but we Egyptians will endure and unceasingly toil for the sake of a permanent peace for all, regardless of gender, colour, nationality or and faith, in the Middle East.

In essence, it is imperative to humanity to cleanse its soul of the 626 mass slaughters of the Qurayzans, the 1915-17 of the Armenians, the 139-1945 of the Jews and of the many Greeks, Serbs and Copts by the ancestors of Erdogan and the Maspero and Libyan Copts by the dogmatic recruits of Haj-Obama. Culturally, it is gratifying to get consumed in the rationalization What If Consciousness Is Not What Drives the Human Mind? versus Is Consciousness an Illusion? Consult "DC Dennett, From Bacteria to Bach and Back: The Evolution of Minds - February 20 2018 by W. W. Norton Company". Nevertheless, neither the "God Gene" nor these intellectual elaborations would convincingly probe the core genesis of the Nazi crimes within the complex biological domain of human's brain. Moreover, recent scientific argumentations shed lights on the intricacy of human brains vis-à-vis the Consciousness an Illusion, viz., extracted Figures D and E. 

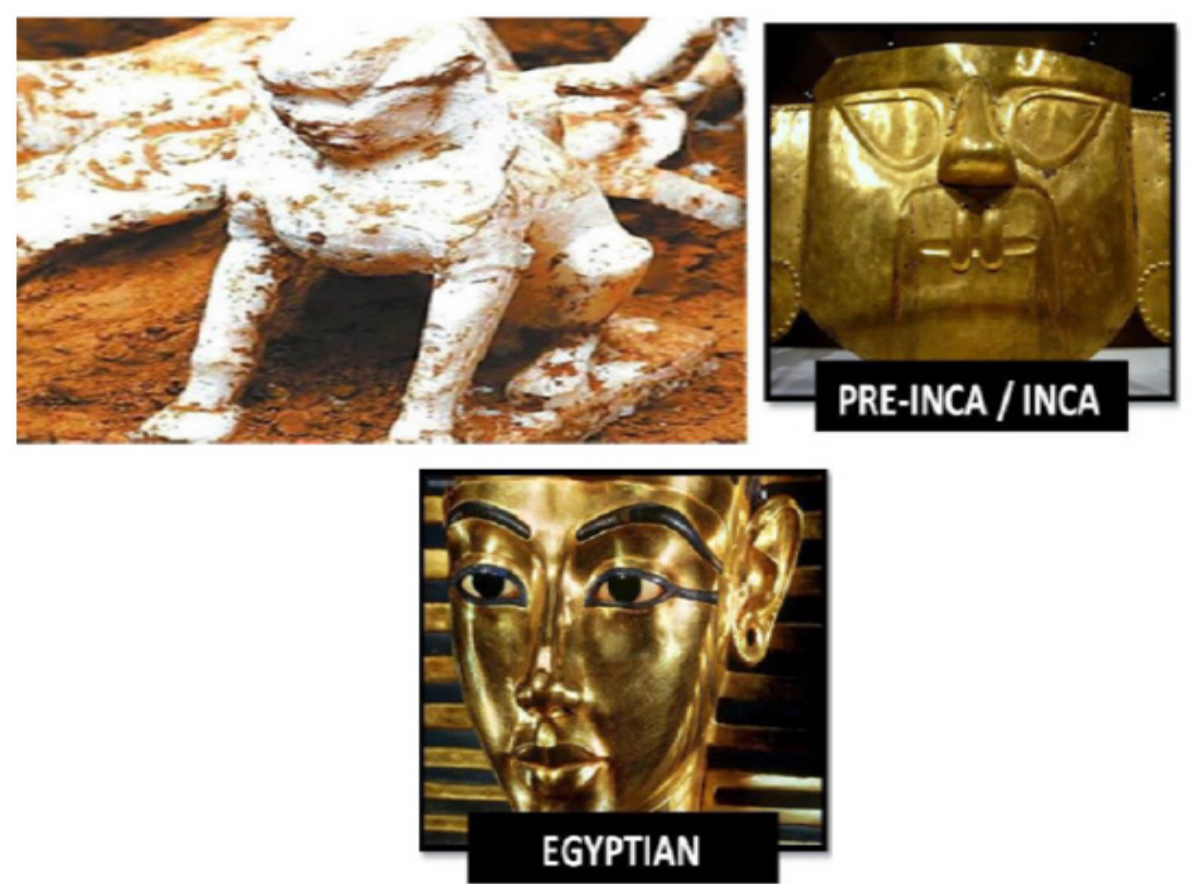

The Sphinx in Chine (Portrait 5)

Most likely DNA circuits of aggression and cannibalization did not evolve but remained intact while Darwinism begat humans from ancestral beasts. At this point of brain storming, it is most advantageous to untie ourselves of the narcissistic and superfluous religious and national sentiments. These sentiments are absolutely suffocating to mental transparency and clarity, thus, abortive to collective rationalism. Should rationalism prevailed in an earlier scrutiny of human tendencies to commit the 626 slaughter of the Qurayzans vis-à-vis the political monopolies to scheme the religious narcissism by Mr. Hempher, G Bell and TE Lawrence, humanity could have escaped said calamitous events. Further, these DNA-inherited ricochets may tell on laypersons - with limited consciousness - applauding of the beastly consumption of the feeble by the gladiators in Nero's arenas. It is not surprising to note: current politicians are extrapolating the human residue of Cain and Able to shoe-shine the specifics of a narrow political scope. For example, Haj-Obama's synthesis of the Arab Spring and the past
4 years of de-novo Nero's polishing of the very same DNA-dark human sentiments was to solely service their personal ambitions and that of the US fat cats. It is our contention,, the Maître d'hôtel and Biden are happily wasting tax payer money to pose differently radical to issues of societal services, but both are assigned to flare radicalism into the service of MIC sole-management of the oil fields. While, the Maître d'hôtel is enlisting the Nazi-white supremacists for the cause, $\mathrm{H}$ Clinton and Obama left Biden with an expanse of inheritance of the dogmatic radicals and Wahhabis. Nazi-white supremacists and radical Wahhabism are two different faces for the same coin of violence and physical elimination of their opponents.

Should Biden prevail as a president, $\mathrm{H}$ Clinton and Haj-Obama would orchestrate pulling the supporting strings of the $79 \mathrm{y}$ president, thus a second wave of Arab Spring is an amenable eventuality, primarily to plough the Middle East and crude oil fields.

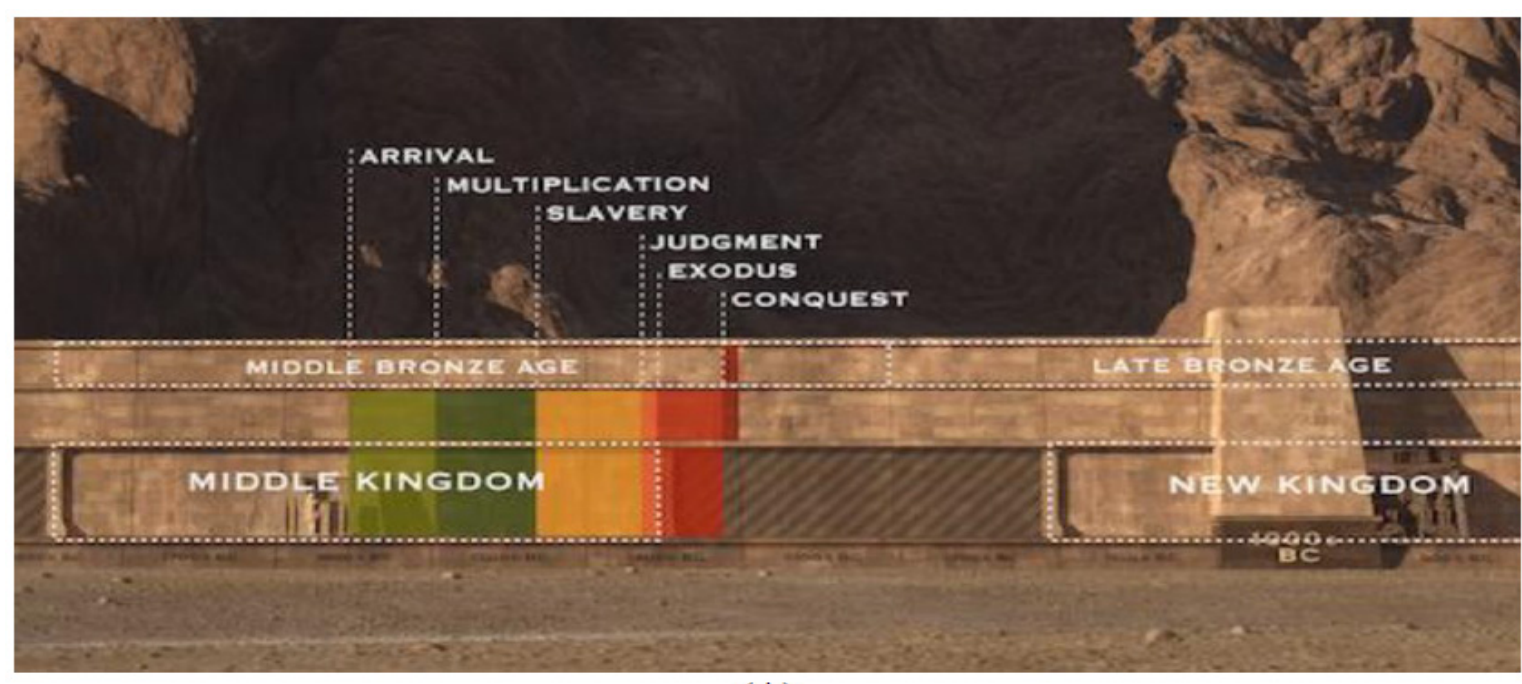

(A)

Citation: JH Wassili, Cyril Baradaeus. Post Freudian Moses and Monotheism. The Eclipse of the Dawn of Conscience Egypt, the 1928 implant of Dogmatic Aberrations, Environmental Necrosis and Mutation of Tropical Diseases. World J Agri \& Soil Sci. 6(3): 2020. 


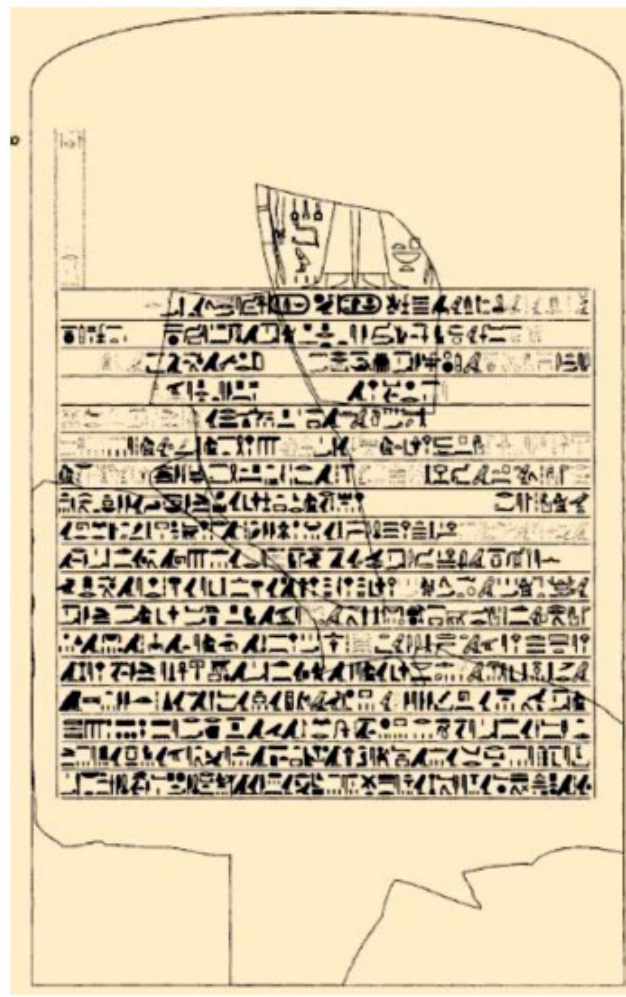

(B)

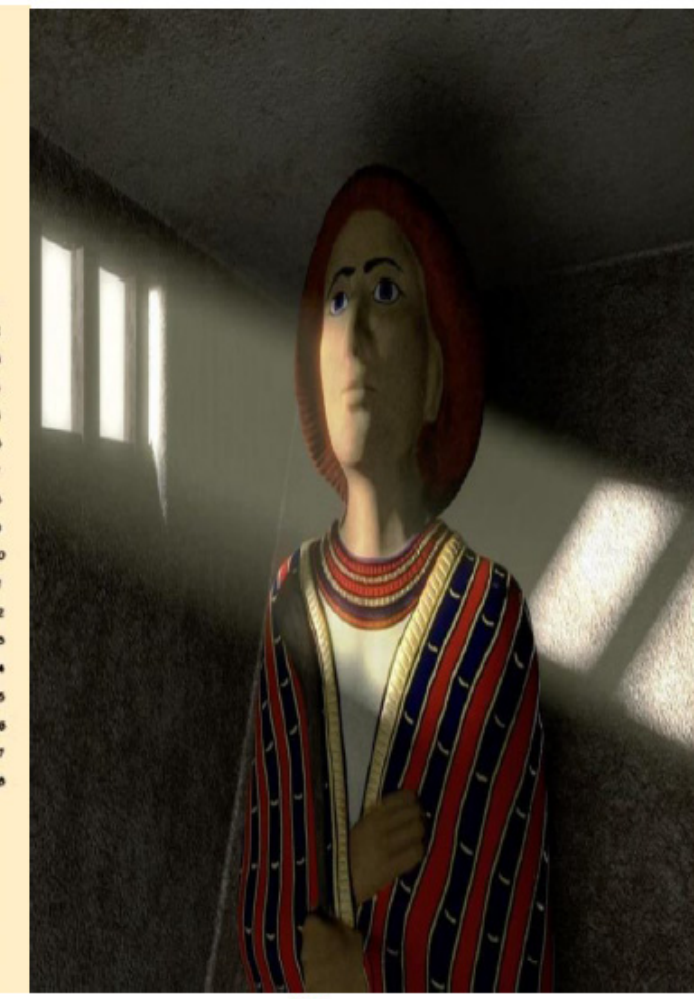

(C)

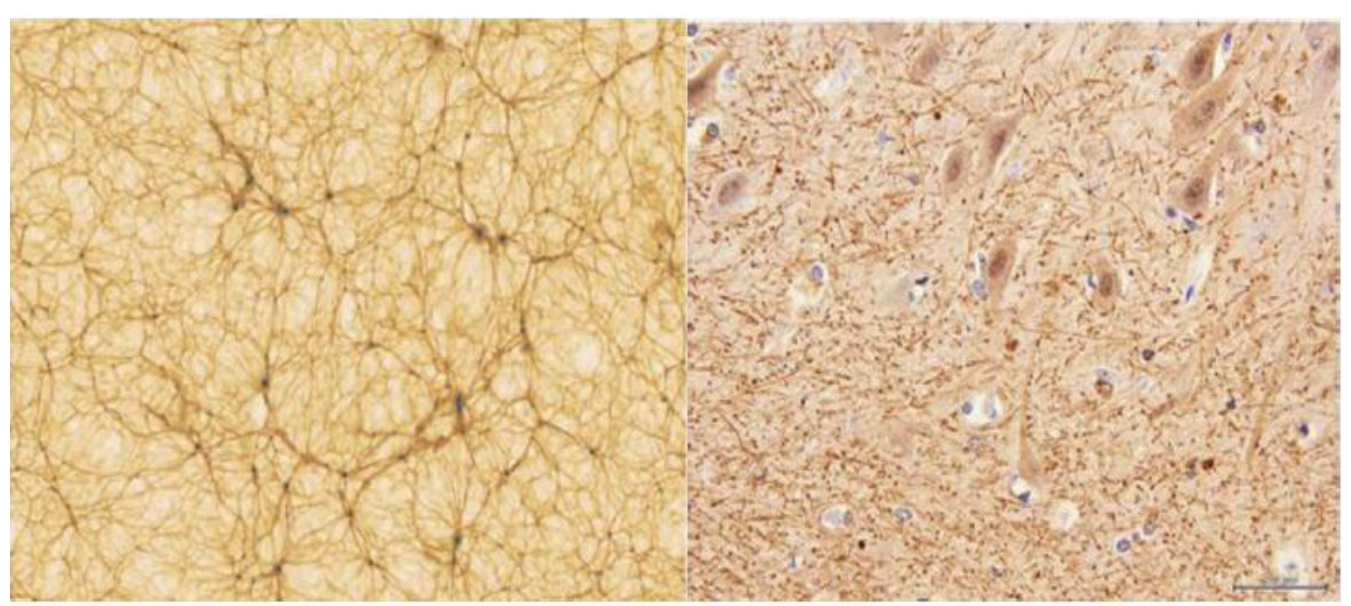

D-Lookalikes: A simulated matter distribution of the cosmic web (left) versus the distribution of neuronal bodies in the cerebellum (right). Source: F Vazza, A Feletti, The Strange Similarity of Neuron and Galaxy Networks Your life's memories could, in principle, be stored in the universe's structure. Nautilus, July 2017. 


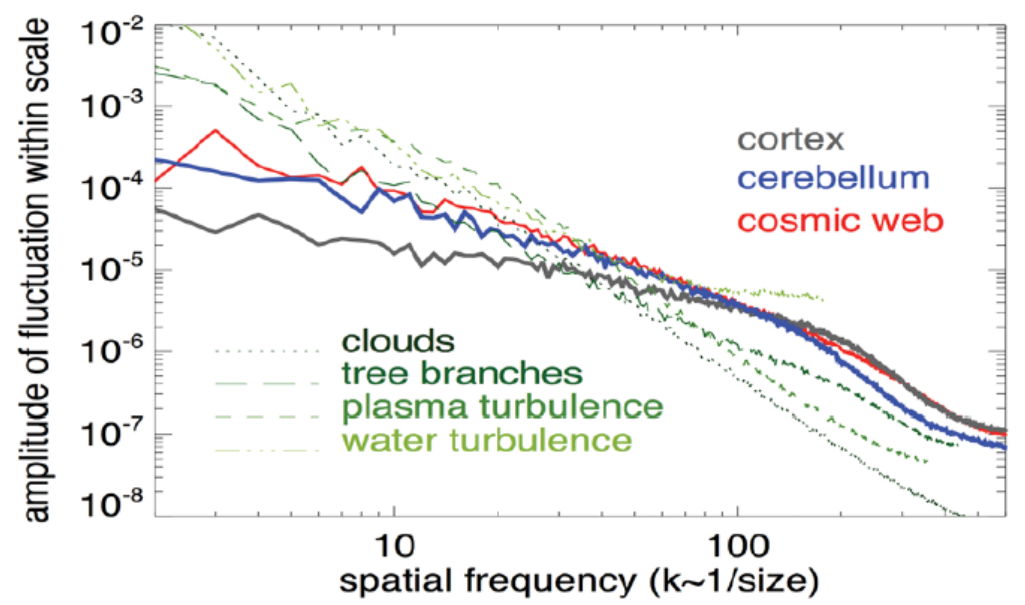

E-Fingerprints: Distribution of fluctuations as a function of spatial scale for the same maps of Fig 1 (with the additional analysis of a thin slice through the human cortex). For comparison, the power spectral density of clouds, tree branches, and plasma and water turbulence are shown.

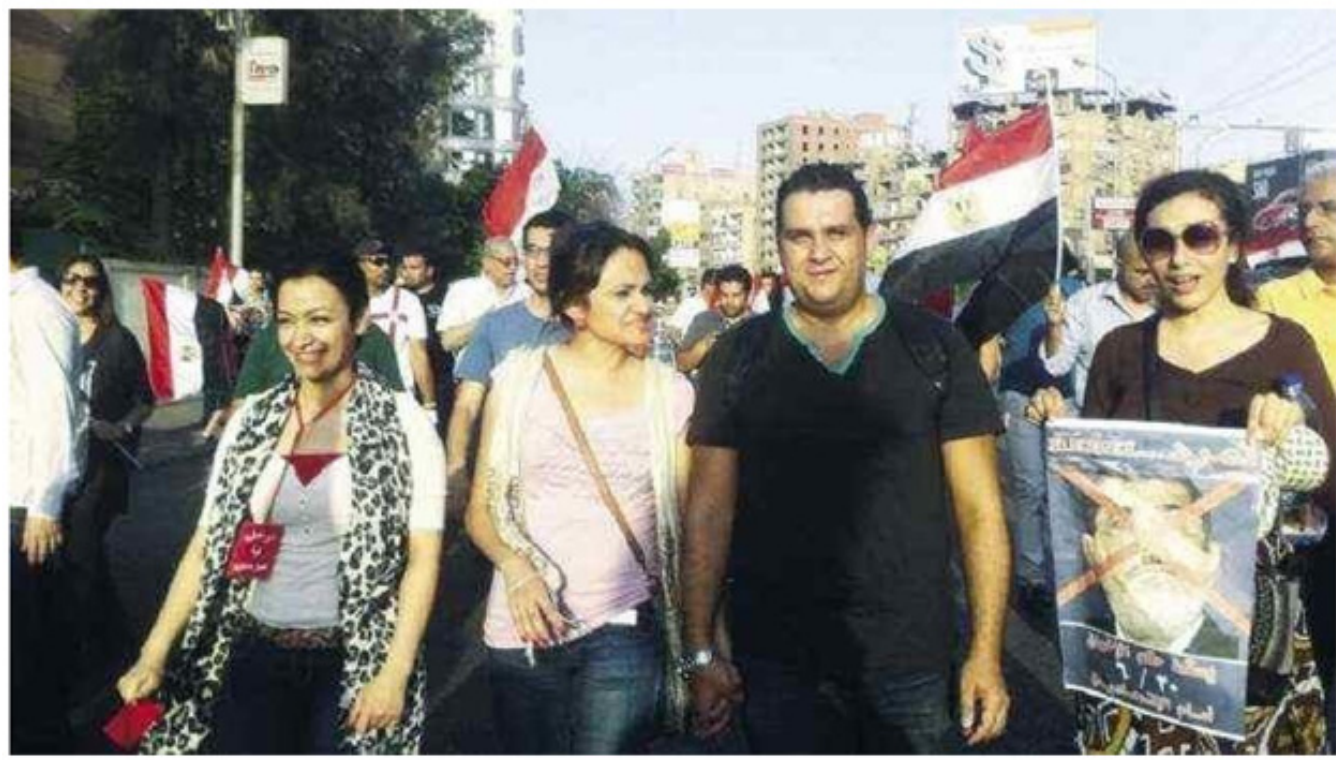

Our beautiful ladies, Isis, Hatshipsut, and Noufiertari revolted against the theocracy of Mursi and brought him to his knees.

Thus, with high degree of certainty, it could be hypothesized above crimes of organized slaughter of members of a specific clan are not a fortuitous protrusion in the moral genetic code but rather a continual saga of the Cain and Abel's mythology. Regardless of the substantial time interval viz., the mechanistic details - specifically the burial of the 622 decapitated Qurayzans and the 1939-45 Naziextermination of the Jews, the 641-nomadic massacres of the Copts and the genocide of the Greeks, Serbs and 1915-17 of the Armenians by the Turks are at the same wave length of bloodthirstiness.
Briefly, it is the nomadic faculties dilled in the darkness of spiritual paralysis to assail the cultured. Scrutinize the obliteration of the Ancient Egyptian, Mesopotamian-Babylonian, Assyrian, Persian, Hebrew and Berber-Amazighs cultures by the 641 nomads, Marco Polo's assisted the Mongols to invade the Yuan dynasty (126773), fall of Constantinople (1453), etc. The question is: are these historical events of racial violence related to the 1939-45 genocide of the Jews? The answer is definitely YES (Figure 9).

(A) Volume ml Ejaculated Semen

\begin{tabular}{|c|c|c|c|c|c|}
\hline Condition & Kidney Failure & HCV-4b & Diabetics & Diabetics + HCV-4b & HCV-4b + Schistosoma \\
\hline $70-80 y(11)^{*}$ & $0.00-0.3$ & $0.00-0.05$ & 0 & 0 & 0 \\
\hline $60-70 y(23)^{* *}$ & $0.2-0.5$ & $0.1-0.3$ & 0.2 & 0.1 & 0.2 \\
\hline $40-60 y(100)$ & $1.8-2.1$ & $1.3-1.7$ & 1.1 & 0.9 & 0.9 \\
\hline $15-40 y(200)$ & $2.8-3.2$ & $2.6-3.1$ & $2.1-2.6$ & $2.0-2.4$ & $1.8-2.5$ \\
\hline
\end{tabular}


(B) \% Average Distribution Still/Necrotic and Morphologically Deformed Sperm to Healthy Controls

\begin{tabular}{|c|c|c|c|c|c|}
\hline Condition & Kidney Failure & HCV-4b & Diabetics & Diabetics + HCV-4b & HCV-4b + Schistosoma \\
\hline $70-80 y(11)^{*}$ & $>94 \%$ & NSD & NA & NA & NA \\
\hline $60-70 y(23)^{* *}$ & $>81 \%$ & $>83 \%$ & $>89 \%$ & $>92 \%$ & NSD \\
\hline $40-60 y(100)$ & $50-70 \%$ & $<74 \%$ & $>81 \%$ & $>92 \%$ & $>96 \%$ \\
\hline $15-40 y(200)$ & $55-67 \%$ & $<63 \%$ & $<68 \%$ & $>78 \%$ & $>78 \%$ \\
\hline
\end{tabular}

(C) \% Decrease in Proteins of Semen Homogenate Relative to Healthy Controls.

\begin{tabular}{|c|c|c|c|c|c|}
\hline Condition & Kidney Failure & HCV-4b & Diabetics & Diabetics + HCV-4b & HCV-4b + Schistosoma \\
\hline $70-80 y(11)$ & $>82$ & $>80$ & NA & NA & NA \\
\hline $60-70 y(23)$ & $>71$ & $>83$ & $>86$ & $>91$ & $>90$ \\
\hline $40-60 y(100)$ & $>62$ & $>76$ & $>79$ & $>84$ & $>89$ \\
\hline $15-40 y(200)$ & $>52$ & $>59$ & $>73$ & $>87$ & $>86$ \\
\hline
\end{tabular}

${ }^{*}$ Only 4 of the $70-80 \mathrm{y}$ subjects had a mild erection ${ }^{* *}$ While out of the 23 aged range $60-70 \mathrm{y}, 11$ individuals had hardly less than $0.5 \mathrm{ml}$ semen ejaculate. Nonetheless, diagnostics were performed on whatever volume of ejaculate offered by subjects of investigation. For this specific reason, data pertaining to $60-80 y$ old had a higher uncertainty $+30-40 \%$. Uncertainties for age ranged $15-60 y$ is $+10-20 \%$. NSD and NA denote No Sperms were Detected and Not Applicable respectively.

(D) Obama's of Yearly Statistical "Salam alaikum" Distribution of Terror.

\begin{tabular}{|c|c|c|c|c|}
\hline Year & Total incidents & EventsinIsrael & Killed & Iniured \\
\hline 1983 & 3 & 0 & 376 & 195 \\
\hline 1984 & 1 & 0 & 24 & 0 \\
\hline 1985 & 2 & 0 & 19 & 82 \\
\hline 1986 & 1 & I & 22 & 0 \\
\hline 1989 & 1 & I & 16 & 0 \\
\hline 1990 & 1 & I & 11 & 17 \\
\hline 1992 & 2 & I & 32 & 265 \\
\hline 1993 & 4 & 0 & 300 & 1334 \\
\hline 1994 & 6 & 3 & 130 & 492 \\
\hline 1995 & 5 & 3 & 43 & 262 \\
\hline 1996 & 3 & I & 51 & 519 \\
\hline 1997 & 5 & 2 & 81 & 353 \\
\hline 1998 & 2 & 0 & 309 & 4200 \\
\hline 2000 & 4 & 0 & 38 & 0 \\
\hline 2001 & 12 & 6 & 6114 & 6543 \\
\hline 2002 & 46 & 12 & 669 & 1702 \\
\hline 2003 & 19 & 6 & 460 & 2216 \\
\hline 2004 & 30 & 3 & 920 & 3640 \\
\hline 2005 & 15 & 3 & 399 & 1527 \\
\hline 2006 & 8 & I & 319 & 981 \\
\hline 2007 & 7 & I & 893 & 1792 \\
\hline 2008 & 8 & I & 187 & 232 \\
\hline 2009 & 4 & 0 & 58 & 87 \\
\hline 2010 & 15 & 0 & 667 & 1564 \\
\hline 2011 & 19 & 0 & 730 & 1779 \\
\hline 2012 & 14 & 0 & 788 & 2393 \\
\hline 2013 & 20 & 0 & 868 & 2079 \\
\hline 2014 & 36 & 5 & 2120 & 1116 \\
\hline 2015 & 117 & 3 & 3055 & 5490 \\
\hline Until March 2016 & 20 & 0 & 330 & 474 \\
\hline
\end{tabular}




\section{Glory to Isis and the land}

By her firm arm protected! To Egypt's King elected, Raise we our festive songs! Hither advance, oh glorious band, Mingle your joy with ours, Green bays and fragrant flowers Scatter their path along. The laurel with the lotus bounds The victors' brows enwreathing, Let flowers, sweet perfume breathing, Veil their grim arms from sight. Dance, sons of Egypt, circling round, And sing your mystic praises, As round the sun in mazes

Dance the bright stars of night. Unto the powers war's issue dread Deciding, our glances raise we

Thank we our gods and praise we On this triumphant day.

\section{Acknowledgement}

Dawn of Conscience (Egypt) $\longrightarrow$ Akhenaten's Monotheism $\longrightarrow$ Fall of Egyptian dynasties $\longrightarrow$ Re-Akhenatenization $($ Anno Domini 1) $\longrightarrow$ Fall of Rome $\longrightarrow$ Retro-Akhenatenization $622 \longrightarrow$ Fall of Byzantium \& Rome $\longrightarrow$ M Luther's Renaissance $\longrightarrow$ Advances Science - Literature $\longrightarrow$ Western Dominanc $\longrightarrow$ Mr. Hempher, GM Bell \& TE Lawrence $\longrightarrow$ Cruel Capitalism $\longrightarrow$ Demise of JF, RF Kennedy \& ML King - Extinction of cultural luminosity $\longrightarrow$ Reagan, 2 Bushs, Haj-Obama Trump \& Biden $\longrightarrow$ De-novo Dark ages - (MIC) $\longrightarrow$ Eclipse of second Rome $\longrightarrow$ Putin $\longrightarrow$ New Byzantium - Second Constantinople (Moscow)

According to culture and aspirations, human's resentments would yield proportional revolts, Moscow 1991 and Washington DC 2021. It remains our contention; calmly Putin is digesting his peace of flesh (Washington DC 2021) vis-à-vis Bush loudly trumpeting Moscow 1991. However, it may not be a total collapse for humanity. Nature's thermodynamics provided its DNA-buffer of moderation for continual and healthy survival of humanity. That is the evolution of well carved personalities of peace; Putin and Sissi, i.e., the Natural Order History:
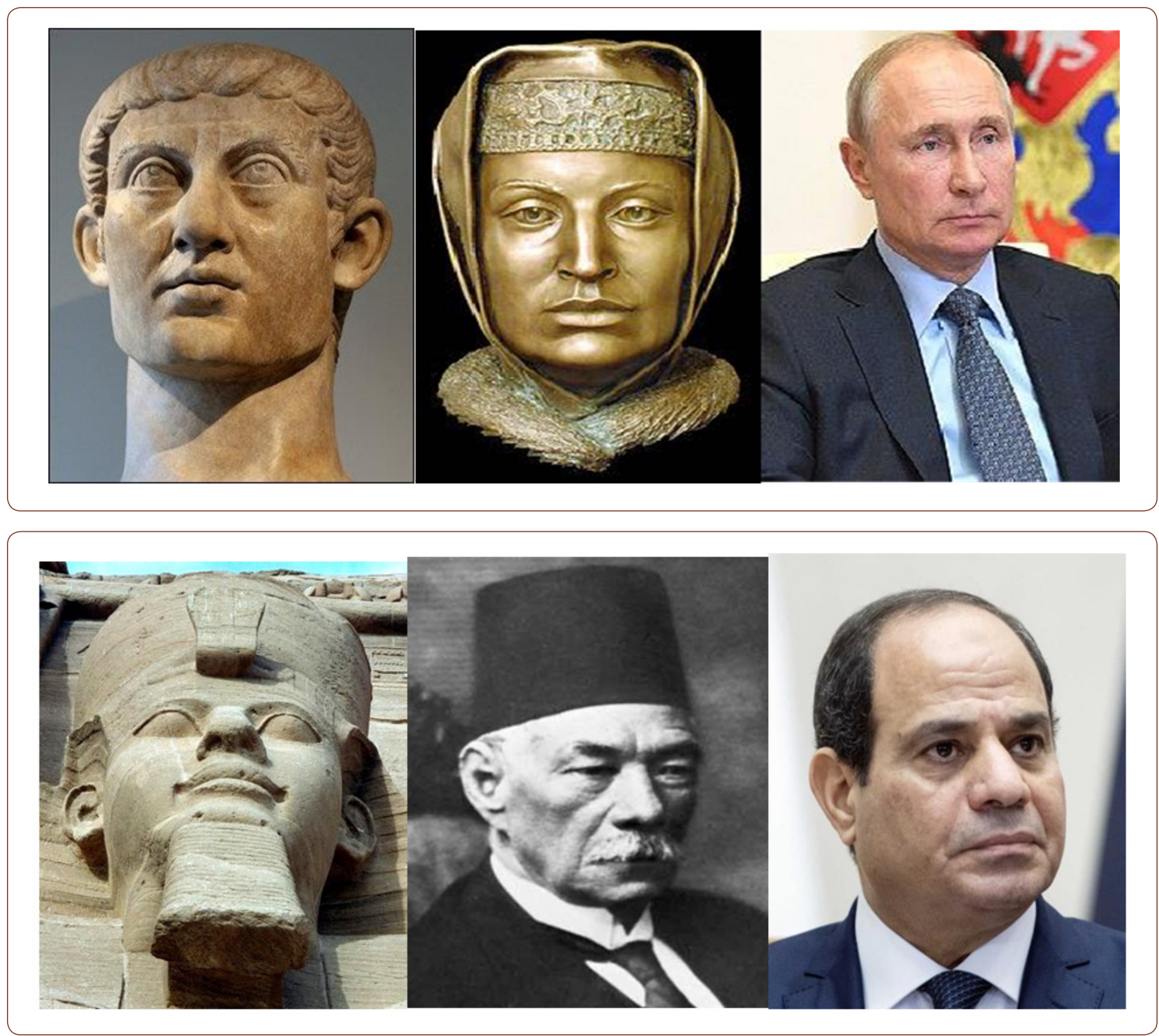

Citation: JH Wassili, Cyril Baradaeus. Post Freudian Moses and Monotheism. The Eclipse of the Dawn of Conscience Egypt, the 1928 implant of Dogmatic Aberrations, Environmental Necrosis and Mutation of Tropical Diseases. World J Agri \& Soil Sci. 6(3): 2020. 
At this point, we should express our gratitude to the World J Agric Soil Science media and the Managing Editor E Megan for approval to circulate the present manuscript. Thus, our multidisciplinary visualization of the current grimly ruined environment is laid onto various desks of chemists with visible conclusions. As possible, the impact of the chronic Western malaise of exaggerating the detailed composition of the theologically different waring nomadic entities, e.g., Sunni Wahhabis versus Shi'ism was detailed in terms of menace to nature. Nonetheless, it is advantageous to all sides to partake in a scientific brain storming of ways and means to revamp the ruined environment. Of course, proponents of Nazisupremacists would fiercely oppose environmental rejuvenation as it is a Chinese conspiracy which would ultimately bankrupt their treasuries of embezzled shares of the masses who toiled to extract natural wealth, why not?

YOU have no enemies, you say?
Alas! my friend, the boast is poor;

He who has mingled in the fray

of duty, that the brave endure,

Must have made foes! If you have none,

Small is the work that you have done.

You've hit no traitor on the hip,

You've dashed no cup from perjured lip,

You've never turned the wrong to right,

You've been a coward in the fight.

\section{(English Chartist poet, 1814-1889)}

While celebrating the aching reminisces of the massive July 2013 revolution against the Nazi axis Haj-Obama-the radical Wahhabi Mursi, we may reflect on the earliest 7000 years covenant of our ancestors with the Omnipotent. The tragic demise of Khaled, Menas and others were not wasted as hatched the presidency of a reformer who cares about the dispossessed; Sissi.

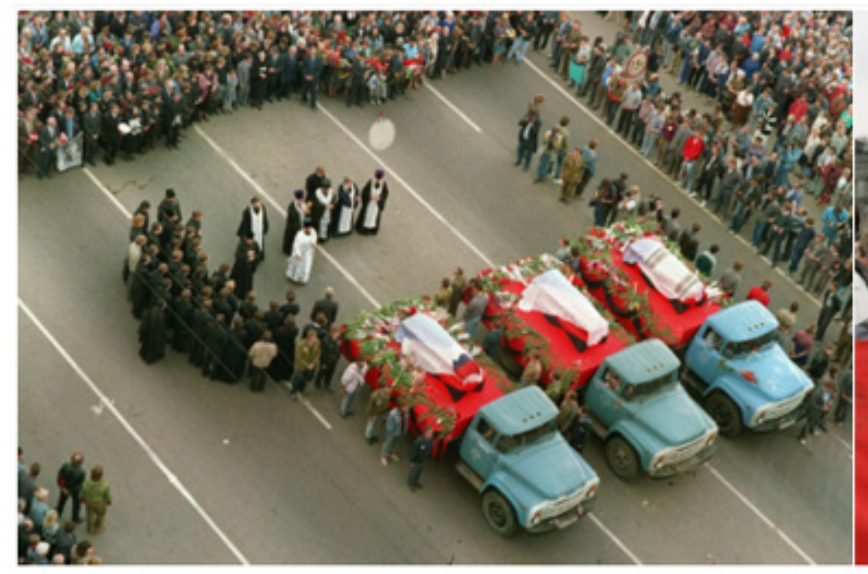

Funeral victims of Moscow 1991

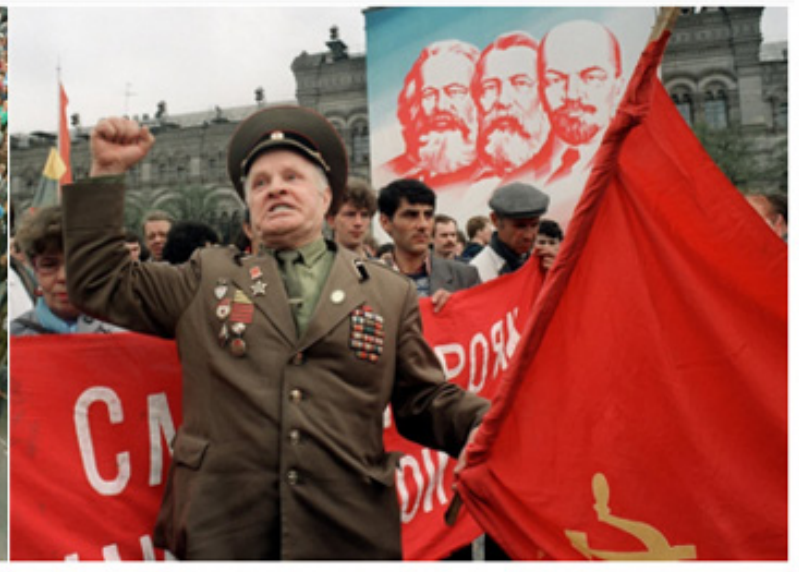

Agitations Moscow 1991

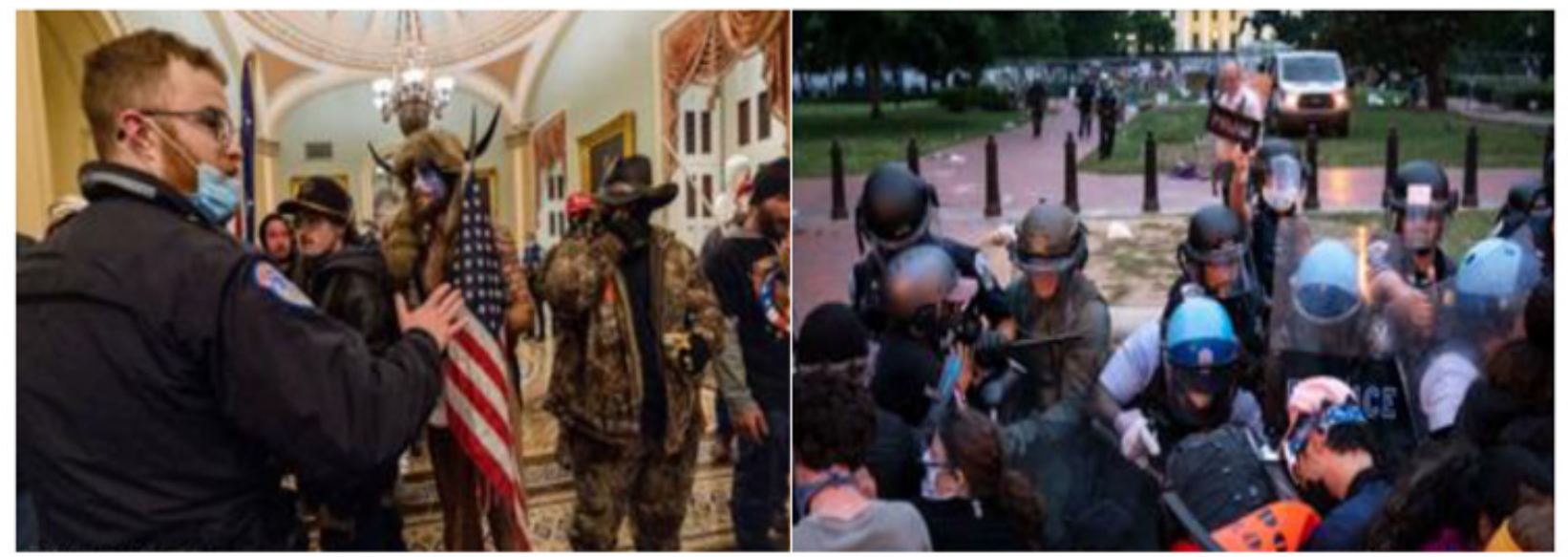

Supremacists and radicals' riots Washington 2021

Nonetheless, those who revel in the resonance of the Pope of the Arabs or the Lion of Upper Egypt: are urged to wisely calculate the risks and long range repercussions of their emotional reactions? The yield of the colonial associations with the dogmatic radicals as of the 1928-British and 1952-US has saturated the details of the nation and could not be erased by a presidential decree. As painful as it is; the religious order should absorb the obscene act committed against a 71 years old lady with refined dignity. Uncalculated flares by the politically unwise clerics would perforate the secular foundation of the nation. At this particular time, the axis Libyan front-Erdogan-Ethiopian dam has the precedence to tackle. Once this radical dogmatism is unravelling, local sectarian cyclones would dissipate. In this context, the recent reaction of the Egyptian Parliament to the critique posed by the European counterpart is likewise a disgrace to international politicking. At this particular point, we may suggest to the Europeans, who emotionally hired 
their faculties to the imprisoned Wahhabis in Egypt, to show alternative avenues of humanitarian approach? Say, (i) Egypt to release these prisoners to the custody of the Europeans for repatriations to European states to enjoy boundless freedom including amalgamation with the same brand of radical rings in Europe, thus (ii) maximize on stabbing the civilians, burning historic sites, etc. The radical militants, who fled to the eastern Turkish city of Gaziantep as were refused of accommodation in Egypt, are freely metastasising within the US fabric, viz., $<$ getpocket.com/explore/item/the-convert?utm_source=pocketnewtab $>$ while absurdly the US-tax payers were drained into the futilities of building the Mexican wall and a cold war with China.

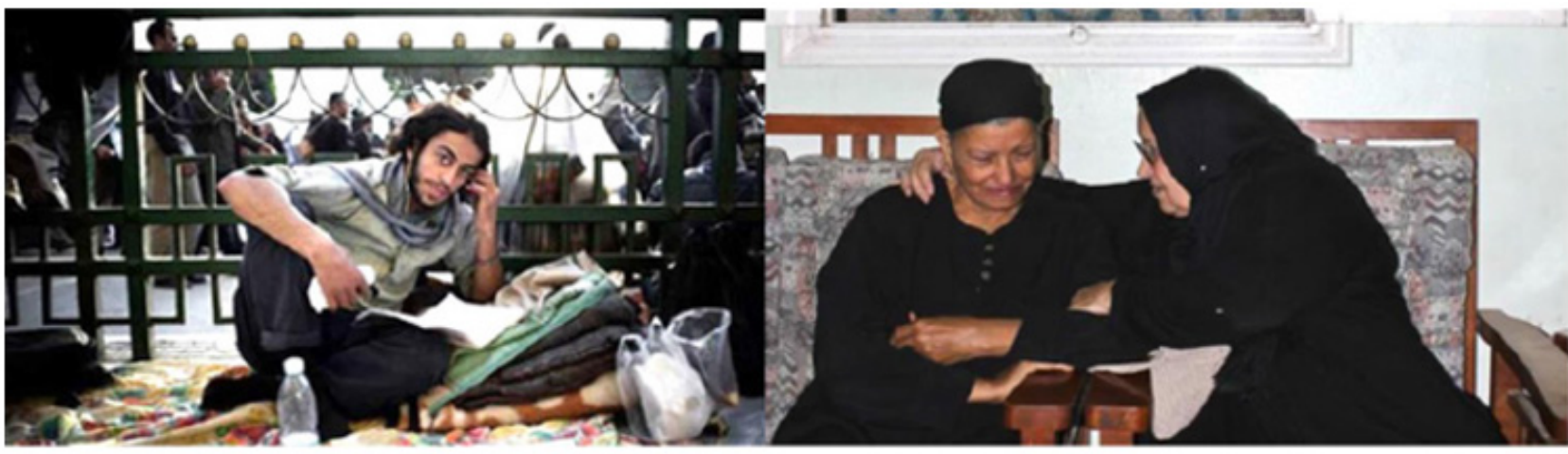

The revolutionary camp of Menas Daniel and mothers of the victims saeed and Daniel condoling each other.

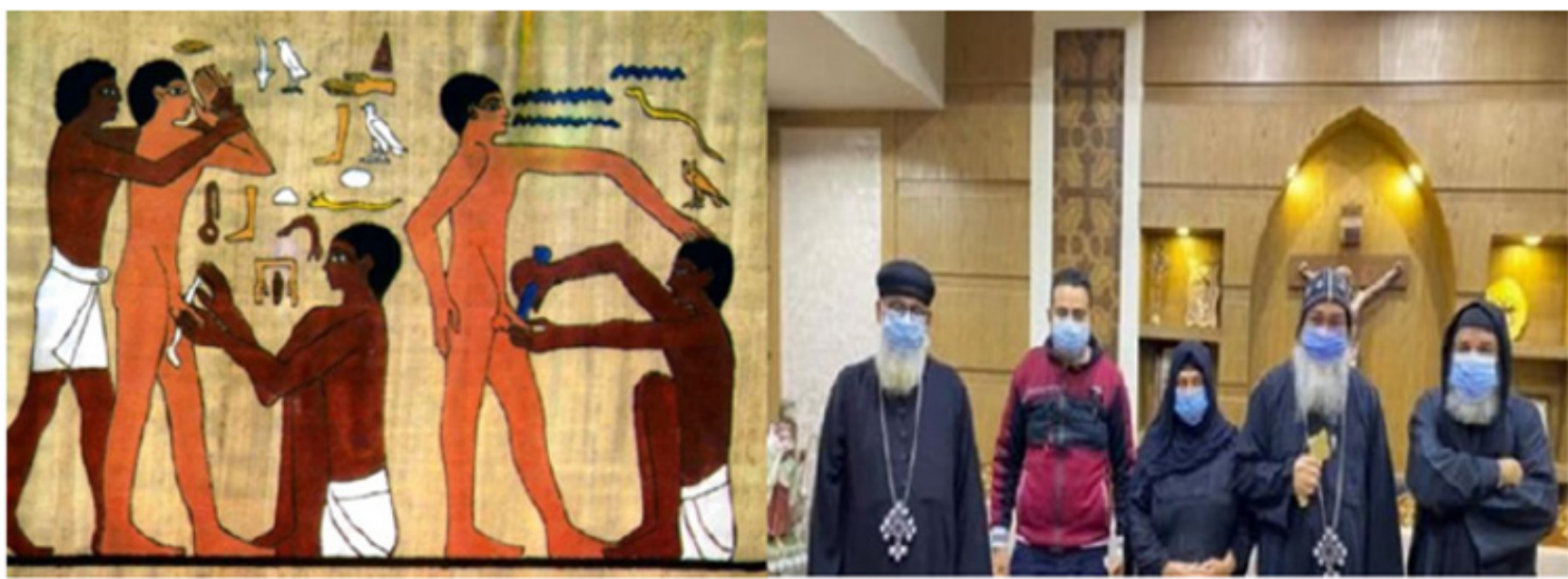

Circumcision in Ancient Egypt; later became a covenant with the Omnipotent.

\section{Conflict of Interest}

No conflict of interest.

\section{References}

1. CG Singer, A Theological Interpretation of American History (2009) Solid Ground Christian Books. ISBN-10-1599252236, S Schuman, JV Dokken, D van Niekerk, RA Loubser, Religious beliefs and climate change adaptation: A study of three rural South African communities, Jàmbá Journal of Disaster Risk Studies, 2018, https://doi.org/10.4102/jamba. v10i1.509, ME Tucker and D R Williams, eds. Buddhism and Ecology: The Interconnection of Dharma and Deeds. Cambridge, Massachusetts: Harvard University Press, 1997, DT Hessel, RR Ruether, eds. Christianity and Ecology: Seeking the Well-being of Earth and Humans. Cambridge, Massachusetts: Harvard University Press, 2000, ME Tucker, J Berthrong, eds. Confucianism and Ecology: The Interrelation of Heaven, Earth, and Humans. Cambridge, Massachusetts: Harvard University Press, 1998, NJ Girardot, J Miller, L Xiaogan, eds. Daoism and Ecology: Ways Within a Cosmic Landscape. Cambridge, Massachusetts: Harvard University Press, 2001 and CK Chapple, ME Tucker, eds., Hinduism and Ecology: The Intersection of Earth, Sky, and Water. Cambridge, Massachusetts: Harvard University Press, 2000.
2. The State of the World's Cities Report (2006/2007) 30 Years of Shaping the Habitat Agenda. The United Nations Settlements Program.

3. (1967) The Long Reach of L White Jr's The Historical Roots of Our Ecologic Crisis, Ecology and Evolution 3736: 155.

4. LA McKinney, EL Kick, GM Fulkerson (2010) World System, Anthropogenic, and Ecological Threats to Bird and Mammal Species: A Structural Equation Analysis of Biodiversity Loss. Organization and Environment 23(1): 3-31.

5. W Colglazie (2015) Sustainable development agenda: 2030. Science 349: 6252, 1048-1050.

6. S Alam, K Hendrik (2015) The Middle East Journal 69(4): 545-562.

7. MAB Deakin (2007) Hypatia of Alexandria: mathematician and martyr Prometheus Books.

8. JK Hoffmeier (2015) Akhenaten and the Origins of Monotheism, Journal of Ancient Egyptian Interconnections 7: 80-83 and S Freud. Moses and Monotheism. Publisher Knoph, 1939.

9. Z Hawass, YZ Gad, S Ismail et al. (2010) Ancestry and Pathology in King Tutankhamun's Family. JAMA 7: 303, 638-647.

10. Ramsis-II, https://en.wikipedia.org/wiki/Ramesses_II

11.S Dando-Collins, The Great Fire of Rome: The Fall of the Emperor Nero and His City. Hachette Books, 2010. 
12. Council of Chalcedon, https://en.wikipedia.org/wiki/Council_of Chalcedon

13. S Runciman (2012) The Fall of Constantinople 1453. Goodreads.

14. RW Roberts (1994) Palace of Fears Random House, Canada, ISBN-13: 978-0394220635.

15. Hitler Stole my Ideas. https://www.amazon.com/Hitler-Stole-IdeasJames-Bellini/dp/B00D5EFKIA

16. G Meir. https://www.brainyquote.com/quotes/golda_meir_115966

17. G Meir. https://www.azquotes.com/quote/497703

18. JH Wassili, Cyril Baradaeus (2017) The dispossessed of Egypt, Part I: Anatomy of hepatic-APR to environmental filth and VMAT2's variantinduced psychosis in aseptic rat models. Research and Review Insights OAT 1(3): 1-8, JH Wassili and Cyril Baradaeus, The dispossessed of Egypt Part II: Beyond the point of fatigue; the export of HCV-4b, mutated diseases and psychological aberrations to the new and old worlds Research and Review Insights OAT 1(3): 1-23, 2018 and JH Wassili and Cyril Baradaeus, The silent biological Hiroshima: GMOs-Induced Darwinian devolution of human race, Research and Review Insights OAT 1(4): 1-12.

19. Gertrude Bell, https://www.thefamouspeople.com/profiles/gertrudebell-30341.php

20. TE Lawrence. https://en.wikipedia.org/wiki/T._E._Lawrence

21. (1833) Peace Agreement of Kütahya, ended the Egyptian-Ottoman War (1831-1833). https://en.wikipedia.org/wiki/Convention of_K\%C3\%BCtahya

22. Egyptian-Ottoman War (1831-33). http://self.gutenberg.org/articles/ eng/Egyptian-Ottoman_War_1831-33.

23. Greco-Turkish War (1919-1922). https://en.wikipedia.org/wiki/Greco Turkish_War_(1919\%E2\%80\%931922)

24. Sophia Palaiologina (1977) https://en.wikipedia.org/wiki/Sophia Palaiologina; ND Connell, R Gould, The Public Health Effects of Biological Weapons. War and Public Health, SB Levy and VW Sidel (eds.), New York; Oxford University Press, pp. 98-116.

25. Airag - Fermented Mare's Milk - Mongolian Beverage, https://www. mongolfood.info/en/recipes/airag.html

26. The World History of Rashid al-Din, 1314, https://en.wikipedia.org/ wiki/Rashid-al-Din_Hamadani

27. The Middle Eastern Drink Arak, https://www.thespruceeats.com/arakmiddle-eastern-alcoholic-beverage-2355492

28. BS Levy, C Lee, BS Shahi (1997) The Environmental Consequences of War. In BS Levy and VW Sidel (Eds) Was and Public Health, New York Oxford University Press, pp. 51-62 and https://www.greenleft.org.au/ content/vietnam-war-and-environment.

29. J Christensen, TK Grønborg, MJ Sørensen, et al., (2013) Prenatal Valproate Exposure and Risk of Autism Spectrum Disorders and Childhood Autism. JAMA 309: 1696-1703.

30. F Krauer, M Riesen, L Reveiz, et al., (2017) Zika Virus Infection as a Cause of Congenital Brain Abnormalities and Guillain-Barré Syndrome. PLoS Med 14(1).

31. D Randal (2009) Toxic munitions cause of baby deaths and deformities in Fallujah. Global Research.

32. S Whitaker (2002) Preventing Violent Conflict: A Revised Mandate for the Public Health Professionals? J Pub Health Policy 34: 46-54 and Hoendoorm and Prokosch 2002.

33. A Mysterious, Slight Increase in Birth Malformations in Rural France https://www.realclearscience.com/articles/2019/03/08/a mysterious_slight_increase_in_birth_malformations_in_rural_ france_110908.html

34. Pompey, https://en.wikipedia.org/wiki/Pompeia_(gens)\#Pompeii_of_ imperial_times

35. Oliver Cromwell - Definition, Facts \& Head - History. https://www. history.com/topics/british-history/oliver-cromwell

36. Case No. F-2014-20439 Dec No. C05784516 Date 2011-11-23 17:41 from Jake Sullivan to H. Clinton, Re; Intel Secret Offer to El Baradei/mbArmy Alliance.

37. AR Pierce (2014) US "Partnership" with the Egyptian Muslim Brotherhood and its Effect on Civil Society and Human Rights. Soc 51 68-86; Secretary of State Hillary R. Clinton, "Remarks at the Release of the13th Annual Report on International Religious Freedom, Washington D.C., (U.S. Department of State, September 13, 2011); Egyptian Governor Blames Obama for Burned Churches. https://www.nationalgeographic. com/news/2014/5/140502-egypt-muslim-brotherhood-morsimubarak-mallawi-world/, McCarthyism, https://en.wikipedia.org/ wiki/McCarthyism

38. https://www.snopes.com/fact-check/ronald-reagan-taliban-photo/

39. SJ Kunitz (2004) The Making and Breaking of Yugoslavia and Its Impact on Health. Am J Public Health 94: 1894-1904.

40. President Eisenhower delivers Cold War "domino theory" speech. https://www.history.com/.../eisenhower-gives-famous-dominotheory-speech.

41. Post-Traumatic Stress Disorder (PTSD): <cmha.ca/documents/posttraumatic-stress-disorder-ptsd> February 27, 2016.

42. Christie's to auction "grave robbed" artefacts. https://perunews wordpress.com/2007/05/12/christies-to-auction-grave-robbedartefacts

43. Google details of L Malandains' circulars and Egypt: Scores killed in New Year's Eve bombing outside packed Coptic church. https://www. socialistworld.net/2011/01/10/egypt-scores-killed-in-new-years-evebombing-outside-packed-coptic-church/

44. Text: Obama's Speech in Cairo. https://www.nytimes.com/2009/06/04/ us/politics/04obama.text.html/

45. Fattawi Shaik MM Sha'arawi (1981) Dar al Qualam 1: 51-53.

46. H TsujII (1977) Rice economy and Rice policy in South Vietnam up to 1974. An Economic and Statistical Analysis South East Asian Studies, 15: 263-294.

47. DS Saba (2009) Afghanistan: Environmental degradation in a fragile ecological setting. International J Sustainable Development and World Ecology, 279-289.

48. Tragedy and Horror of Rwandan Genocide < https://studydriver.com/ tragedy-and-horror-of-rwandan-genocide/>

49. https://www.gov.uk/dfid-research-outputs/environmental-issues-inethiopia-and-links-to-the-ethiopian-economy

50. GR Lotuto, S Marlborough (2010) Toxicity and bioaccumulation of TNT in marine fish in sediment exposures, Ecotoxicology and Environmental Safety 73: 1720-727.

51.J Bowlby (1995) Maternal Care and Mental Health. The master work series (2nd ed.). Northvale, NJ; London: Jason Aronson. ISBN 978-156821-757-4, Geneva, World Health Organization, Monograph series no. 3, J Bowlby (1969) Attachment. Attachment and Loss (vol. 1) (2nd ed.). New York: Basic Books. ISBN 0-465-00543-8. NLM 8412414, 1999 , D Machairas. The Strategic and Political Consequences of the June 1967 War. Cogent Social Science 3: 1299555, R Hinnebusch (2017) Revisiting the 1967 Arab-Israel War and its Consequences for the Regional System. British J Middle Eastern Studies 44: 4, Y Goldstein (2018) The Sis Day War: The War that no One Wanted. Israel Affairs 24: 767-784, and MA Shakur, S Mehhana, NS Hopkins (2005) War and Forced Migration in Egypt: The Experience of Evacuation from the Suez Canal Cities. Arab Studies Quarterly 27: 21-39.

52. Y Haddad, JD Onovan (2013) Good Copt, Bad Copt: Competing Narratives on Coptic Identity in Egypt and the United States, Studies in World Christianity 19(3): 208-232.

53. S Freud, Civilization and its Discontent, London, Penguin Press, ISBN 978-0-14-118236-0.

54. Biblical Archaeology Documentary, Timeline, YouTube - World History Documentaries.

55. B Lewis (1991) The Political Language of Islam, University of Chicago Press, Exxon Lecture. 